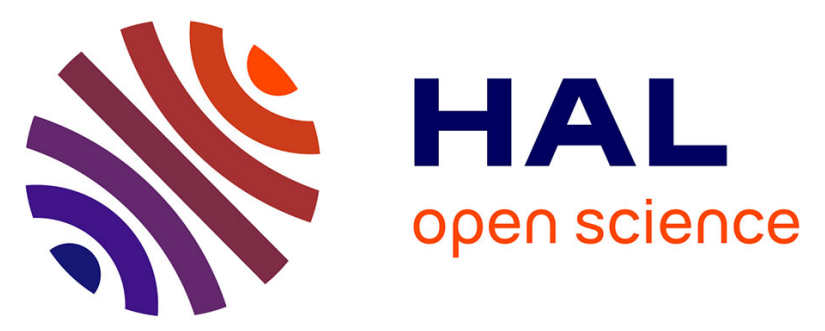

\title{
Profil moléculaire des patients atteints de cancer bronchique compliqué de métastases cérébrales inclus dans l'essai de recherche clinique SAFIR 02 LUNG et évolution cérébrale sous traitement
}

Alice Mogenet

\section{To cite this version:}

Alice Mogenet. Profil moléculaire des patients atteints de cancer bronchique compliqué de métastases cérébrales inclus dans l'essai de recherche clinique SAFIR 02 LUNG et évolution cérébrale sous traitement. Sciences du Vivant [q-bio]. 2021. dumas-03266331

\section{HAL Id: dumas-03266331 \\ https://dumas.ccsd.cnrs.fr/dumas-03266331}

Submitted on 21 Jun 2021

HAL is a multi-disciplinary open access archive for the deposit and dissemination of scientific research documents, whether they are published or not. The documents may come from teaching and research institutions in France or abroad, or from public or private research centers.
L'archive ouverte pluridisciplinaire HAL, est destinée au dépôt et à la diffusion de documents scientifiques de niveau recherche, publiés ou non, émanant des établissements d'enseignement et de recherche français ou étrangers, des laboratoires publics ou privés. 
Profil moléculaire des patients atteints de cancer bronchique compliqué de métastases cérébrales inclus dans l'essai de recherche clinique SAFIR 02

LUNG et évolution cérébrale sous traitement

\section{T H E S E A A R T I C L E}

Présentée et publiquement soutenue devant

LA FACULTÉ DES SCIENCES MEDICALES ET PARAMEDICALES

DE MARSEILLE

Le 18 Juin 2021

Par Madame Alice MOGENET

Née le 23 octobre 1992 à Avignon (84)

Pour obtenir le grade de Docteur en Médecine

D.E.S. de PNEUMOLOGIE

Membres du Jury de la Thèse :

Monsieur le Professeur BARLESI Fabrice

Président

Monsieur le Professeur GREILLIER Laurent

Assesseur

Monsieur le Professeur BERTUCCI François

Assesseur

Madame le Docteur (MCU-PH) TOMASINI Pascale

Directeur 

Profil moléculaire des patients atteints de cancer bronchique compliqué de métastases cérébrales inclus dans l'essai de recherche clinique SAFIR 02

LUNG et évolution cérébrale sous traitement

\section{T H E S E A A R T I C L E}

Présentée et publiquement soutenue devant

LA FACULTÉ DES SCIENCES MEDICALES ET PARAMEDICALES

DE MARSEILLE

Le 18 Juin 2021

Par Madame Alice MOGENET

Née le 23 octobre 1992 à Avignon (84)

Pour obtenir le grade de Docteur en Médecine

D.E.S. de PNEUMOLOGIE

Membres du Jury de la Thèse :

Monsieur le Professeur BARLESI Fabrice

Président

Monsieur le Professeur GREILLIER Laurent

Assesseur

Monsieur le Professeur BERTUCCI François

Assesseur

Madame le Docteur (MCU-PH) TOMASINI Pascale

Directeur 


\section{FACULTÉ DES SCIENCES MÉDICALES \& PARAMÉDICALES}

\section{Doyen}

Vice-Doyen aux affaires générales

Vice-Doyen aux professions paramédicales

Conseiller
Pr. Georges LEONETTI

: Pr. Patrick DESSI

: Pr. Philippe BERBIS

: $\quad$ Pr. Patrick VILLANI

\section{Assesseurs :}

aux études

à la recherche

$>$ à l'unité mixte de formation continue en santé

$>$ pour le secteur NORD

$>$ Groupements Hospitaliers de territoire

$>$ aux masters
Pr. Kathia CHAUMOITRE

Pr. Jean-Louis MEGE

Pr. Justin MICHEL

Pr. Stéphane BERDAH

Pr. Jean-Noël ARGENSON

Pr. Pascal ADALIAN

\section{Chargés de mission :}

sciences humaines et sociales

$>$ relations internationales

$>$ DU/DIU

$>$ DPC, disciplines médicales \& biologiques

$>$ DPC, disciplines chirurgicales
: $\quad$ Pr. Pierre LE COZ

: $\quad$ Pr. Stéphane RANQUE

: Pr. Véronique VITTON

: $\quad$ Pr. Frédéric CASTINETTI

: Dr. Thomas GRAILLON

\section{ÉCOLE DE MEDECINE}

\section{Directeur}

\section{Chargés de mission}

- PACES - Post-PACES

- DFGSM

- DFASM

- DFASM

- Préparation aux ECN

- DES spécialités

- DES stages hospitaliers

- DES MG

- Démographie médicale

- Etudiant
Pr. Jean-Michel VITON

$\begin{array}{ll}: & \text { Pr. Régis GUIEU } \\ : & \text { Pr. Anne-Laure PELISSIER } \\ : & \text { Pr. Marie-Aleth RICHARD } \\ : & \text { Pr. Marc BARTHET } \\ : & \text { Dr Aurélie DAUMAS } \\ : & \text { Pr. Pierre-Edouard FOURNIER } \\ : & \text { Pr. Benjamin BLONDEL } \\ : & \text { Pr. Christophe BARTOLI } \\ : & \text { Dr. Noémie RESSEGUIER } \\ : & \text { Elise DOMINJON }\end{array}$




\section{ÉCOLE DE MEDECINE DENTAIRE}

Directeur

:

Pr. Bruno FOTI

\section{ÉCOLE DE DE MAIEUTIQUE}

Directrice

Madame Carole ZAKARIAN

Chargés de mission

- $1^{\text {er }}$ cycle

- $2^{\text {ème }}$ cycle

Madame Estelle BOISSIER

Madame Cécile NINA

\section{ÉCOLE DES SCIENCES DE LA RÉADAPTATION}

Directeur

Chargés de mission

- Masso-kinésithérapie $1^{\mathrm{er}}$ cycle

- Masso-kinésithérapie $2^{\text {ème }}$ cycle

- Mutualisation des enseignements
Monsieur Philippe SAUVAGEON

Madame Béatrice CAORS

Madame Joannie HENRY

Madame Géraldine DEPRES

\section{ÉCOLE DES SCIENCES INFIRMIERES}

Directeur

Chargés de mission

- Chargée de mission

- Chargé de mission
Monsieur Sébastien COLSON

Madame Sandrine MAYEN RODRIGUES

Monsieur Christophe ROMAN 


\section{PROFESSEURS HONORAIRES}

AGOSTINI Serge

ALDIGHIERI René

ALESSANDRINI Pierre

ALLIEZ Bernard

AQUARON Robert

ARGEME Maxime

ASSADOURIAN Robert

AUFFRAY Jean-Pierre

AUTILLO-TOUATI Amapola

AZORIN Jean-Michel

BAILLE Yves

BARDOT Jacques

BARDOT André

BERARD Pierre

BERGOIN Maurice

BERLAND Yvon

BERNARD Dominique

BERNARD Jean-Louis

BERNARD Jean-Paul

BERNARD Pierre-Marie

BERTRAND Edmond

BISSET Jean-Pierre

BLANC Bernard

BLANC Jean-Louis

BOLLINI Gérard

BONGRAND Pierre

BONNEAU Henri

BONNOIT Jean

BORY Michel

BOTTA Alain

BOTTA-FRIDLUND Danielle

BOURGEADE Augustin

BOUVENOT Gilles

BOUYALA Jean-Marie

BREMOND Georges

BRICOT René

BRUNET Christian

BUREAU Henri

CAMBOULIVES Jean

CANNONI Maurice

CARTOUZOU Guy

CAU Pierre

CHABOT Jean-Michel

CHAMLIAN Albert

CHARPIN Denis

CHARREL Michel
MM DEVRED Philippe

DJIANE Pierre

DONNET Vincent

DUCASSOU Jacques

DUFOUR Michel

DUMON Henri

ENJALBERT Alain

FAUGERE Gérard

FAVRE Roger

FIECHI Marius

FARNARIER Georges

FIGARELLA Jacques

FONTES Michel

FRANCES Yves

FRANCOIS Georges

FUENTES Pierre

GABRIEL Bernard

GALINIER Louis

GALLAIS Hervé

GAMERRE Marc

GARCIN Michel

GARNIER Jean-Marc

GAUTHIER André

GERARD Raymond

GEROLAMI-SANTANDREA André

GIUDICELLI Sébastien

GOUDARD Alain

GOUIN François

GRILLO Jean-Marie

GRIMAUD Jean-Charles

GRISOLI François

GROULIER Pierre

HADIDA/SAYAG Jacqueline

HASSOUN Jacques

HEIM Marc

HOUEL Jean

HUGUET Jean-François

JAQUET Philippe

JAMMES Yves

JOUVE Paulette

JUHAN Claude

JUIN Pierre

KAPHAN Gérard

KASBARIAN Michel

KLEISBAUER Jean-Pierre

LACHARD Jean 
CHAUVEL Patrick

CHOUX Maurice

CIANFARANI François

CLAVERIE Jean-Michel

CLEMENT Robert

COMBALBERT André

CONTE-DEVOLX Bernard

CORRIOL Jacques

COULANGE Christian

CURVALE Georges

DALMAS Henri

DE MICO Philippe

DELPERO Jean-Robert

DESSEIN Alain

DELARQUE Alain

DEVIN Robert

MM MICHOTEY Georges

MIRANDA François

MONFORT Gérard

MONGES André

MONGIN Maurice

MUNDLER Olivier

NAZARIAN Serge

NICOLI René

NOIRCLERC Michel

OLMER Michel

OREHEK Jean

PAPY Jean-Jacques

PAULIN Raymond

PELOUX Yves

PENAUD Antony

PENE Pierre

PIANA Lucien

PICAUD Robert

PIGNOL Fernand

POGGI Louis

POITOUT Dominique

PONCET Michel

POUGET Jean

PRIVAT Yvan

QUILICHINI Francis

RANQUE Jacques

RANQUE Philippe

RICHAUD Christian

RIDINGS Bernard

ROCHAT Hervé

ROHNER Jean-Jacques

ROUX Hubert
LAFFARGUE Pierre

LAUGIER René

LE TREUT Yves

LEVY Samuel

LOUCHET Edmond

LOUIS René

LUCIANI Jean-Marie

MAGALON Guy

MAGNAN Jacques

MALLAN- MANCINI Josette

MALMEJAC Claude

MARANINCHI Dominique

MARTIN Claude

MATTEI Jean François

MERCIER Claude

METGE Paul

VANUXEM Paul

VERVLOET Daniel

VIALETTES Bernard

WEILLER Pierre-Jean 
ROUX Michel

RUFO Marcel

SAHEL José

SALAMON Georges

SALDUCCI Jacques

SAMBUC Roland

SAN MARCO Jean-Louis

SANKALE Marc

SARACCO Jacques

SARLES Jacques

SARLES - PHILIP Nicole

SASTRE Bernard

SCHIANO Alain

SCOTTO Jean-Claude

SEBAHOUN Gérard

SEITZ Jean-François

SERMENT Gérard

SOULAYROL René

STAHL André

TAMALET Jacques

TARANGER-CHARPIN Colette

THIRION Xavier

THOMASSIN Jean-Marc

UNAL Daniel

VAGUE Philippe

VAGUE/JUHAN Irène 


\section{8}

M. le Professeur Mme le Professeur M. le Professeur M. le Professeur M. le Professeur

LEVY Samuel

$31 / 08 / 2011$

JUHAN-VAGUE Irène 31/08/2011

PONCET Michel 31/08/2011

KASBARIAN Michel 31/08/2011

ROBERTOUX Pierre 31/08/2011

2009

M. le Professeur

DJIANE Pierre

$31 / 08 / 2011$

M. le Professeur

VERVLOET Daniel

$31 / 08 / 2012$

\section{0}

M. le Professeur

MAGNAN Jacques

$31 / 12 / 2014$

2011

M. le Professeur

DI MARINO Vincent

$31 / 08 / 2015$

MARTIN Pierre

$31 / 08 / 2015$

METRAS Dominique

$31 / 08 / 2015$

\section{2}

M. le Professeur M. le Professeur M. le Professeur M. le Professeur M. le Professeur M. le Professeur M. le Professeur

AUBANIAC Jean-Manuel 31/08/2015 BOUVENOT Gilles $\quad 31 / 08 / 2015$ CAMBOULIVES Jean 31/08/2015 FAVRE Roger 31/08/2015 MATTEI Jean-François 31/08/2015 OLIVER Charles 31/08/2015 VERVLOET Daniel 31/08/2015

2013

M. le Professeur M. le Professeur M. le Professeur M. le Professeur M. le Professeur M. le Professeur M. le Professeur M. le Professeur

BRANCHEREAU Alain

$31 / 08 / 2016$ CARAYON Pierre $31 / 08 / 2016$ COZZONE Patrick $31 / 08 / 2016$ DELMONT Jean $31 / 08 / 2016$ HENRY Jean-François $31 / 08 / 2016$ LE GUICHAOUA Marie-Roberte $31 / 08 / 2016$ RUFO Marcel $31 / 08 / 2016$ SEBAHOUN Gérard

$31 / 08 / 2016$

\section{4}

M. le Professeur M. le Professeur M. le Professeur M. le Professeur M. le Professeur

FUENTES Pierre

$31 / 08 / 2017$

GAMERRE Marc

$31 / 08 / 2017$

MAGALON Guy

$31 / 08 / 2017$

PERAGUT Jean-Claude

$31 / 08 / 2017$

WEILLER Pierre-Jean

$31 / 08 / 2017$

\section{5}

M. le Professeur M. le Professeur M. le Professeur M. le Professeur M. le Professeur M. le Professeur

COULANGE Christian

$31 / 08 / 2018$ COURAND François $31 / 08 / 2018$ FAVRE Roger $31 / 08 / 2016$ MATTEI Jean-François $31 / 08 / 2016$ OLIVER Charles $31 / 08 / 2016$ VERVLOET Daniel 


\section{6}

M. le Professeur M. le Professeur M. le Professeur M. le Professeur M. le Professeur M. le Professeur M. le Professeur M. le Professeur M. le Professeur M. le Professeur M. le Professeur M. le Professeur M. le Professeur

2017

M. le Professeur M. le Professeur M. le Professeur M. le Professeur M. le Professeur M. le Professeur M. le Professeur M. le Professeur

\section{8}

M. le Professeur M. le Professeur M. le Professeur M. le Professeur M. le Professeur M. le Professeur M. le Professeur

\section{9}

M. le Professeur M. le Professeur M. le Professeur M. le Professeur M. le Professeur M. le Professeur M. le Professeur M. le Professeur M. le Professeur M. le Professeur M. le Professeur M. le Professeur M. le Professeur

\section{0}

M. le Professeur M. le Professeur M. le Professeur M. le Professeur M. le Professeur M. le Professeur M. le Professeur M. le Professeur M. le Professeur M. le Professeur M. le Professeur M. le Professeur
BONGRAND Pierre

$31 / 08 / 2019$

BOUVENOT Gilles

BRUNET Christian

CAU Pierre

COZZONE Patrick

FAVRE Roger

FONTES Michel

JAMMES Yves

NAZARIAN Serge

OLIVER Charles

POITOUT Dominique

SEBAHOUN Gérard

VIALETTES Bernard

ALESSANDRINI Pierre

$31 / 08 / 2020$

$31 / 08 / 2018$

$31 / 08 / 2020$

CHAUVEL Patrick

COZZONE Pierre

DELMONT Jean

FAVRE Roger

OLIVER Charles

SEBBAHOUN Gérard

$31 / 08 / 2018$

$31 / 08 / 2018$

$31 / 08 / 2018$

$31 / 08 / 2018$

$31 / 08 / 2018$

MARANINCHI Dominique

$31 / 08 / 2021$

BOUVENOT Gilles

COZZONE Pierre

DELMONT Jean

FAVRE Roger

OLIVER Charles

RIDINGS Bernard

$31 / 08 / 2019$

$31 / 08 / 2019$

$31 / 08 / 2019$

$31 / 08 / 2019$

$31 / 08 / 2019$

$31 / 08 / 2021$

BERLAND Yvon
CHARPIN Denis
CLAVERIE Jean-Michel
FRANCES Yves
CAU Pierre
COZZONE Patrick
DELMONT Jean
FAVRE Roger
FONTES Michel
MAGALON Guy
NAZARIAN Serge
OLIVER Charles
WEILLER Pierre-Jean

$31 / 08 / 2022$

$31 / 08 / 2022$

$31 / 08 / 2022$

$31 / 08 / 2022$

$31 / 08 / 2020$

$31 / 08 / 2020$

$31 / 08 / 2020$

$31 / 08 / 2020$

$31 / 08 / 2020$

$31 / 08 / 2020$

$31 / 08 / 2020$

$31 / 08 / 2020$

$31 / 08 / 2020$

$31 / 08 / 2023$

$31 / 08 / 2023$

$31 / 08 / 2023$

$31 / 08 / 2023$

$31 / 08 / 2022$

$31 / 08 / 2022$

$31 / 08 / 2022$

$31 / 08 / 2022$

$31 / 08 / 2021$

$31 / 08 / 2021$

$31 / 08 / 2021$

$31 / 08 / 2021$ 


\section{EMERITAT}




\section{Honoris causa}

1967

MM. les Professeurs

1974

MM. les Professeurs

1975

MM. les Professeurs

1976

MM. les Professeurs

1977

MM. les Professeurs

M. le Président

1980

MM. les Professeurs

1981

MM. les Professeurs

1982

M. le Professeur

1985

MM. les Professeurs

1986

MM. les Professeurs
DADI (Italie)

CID DOS SANTOS (Portugal)

MAC ILWAIN (Grande-Bretagne)

T.A. LAMBO (Suisse)

O. SWENSON (U.S.A.)

Lord J.WALTON of DETCHANT (Grande-Bretagne)

P. FRANCHIMONT (Belgique)

Z.J. BOWERS (U.S.A.)

C. GAJDUSEK-Prix Nobel (U.S.A.)

C.GIBBS (U.S.A.)

J. DACIE (Grande-Bretagne)

F. HOUPHOUET-BOIGNY (Côte d'Ivoire)

A. MARGULIS (U.S.A.)

R.D. ADAMS (U.S.A.)

H. RAPPAPORT (U.S.A.)

M. SCHOU (Danemark)

M. AMENT (U.S.A.)

Sir A. HUXLEY (Grande-Bretagne)

S. REFSUM (Norvège)

W.H. HENDREN (U.S.A.)

S. MASSRY (U.S.A.)

KLINSMANN (R.D.A.)

E. MIHICH (U.S.A.)

T. MUNSAT (U.S.A.)

LIANA BOLIS (Suisse)

L.P. ROWLAND (U.S.A.) 
1988

MM. les Professeurs

\author{
R. BERGUER (U.S.A.) \\ W.K. ENGEL (U.S.A.) \\ V. ASKANAS (U.S.A.) \\ J. WEHSTER KIRKLIN (U.S.A.) \\ A. DAVIGNON (Canada) \\ A. BETTARELLO (Brésil)
}

1989

M. le Professeur

P. MUSTACCHI (U.S.A.)

1990

MM. les Professeurs

J.G. MC LEOD (Australie)

J. PORTER (U.S.A.)

1991

MM. les Professeurs

J. Edward MC DADE (U.S.A.)

W. BURGDORFER (U.S.A.)

1992

MM. les Professeurs

H.G. SCHWARZACHER (Autriche)

D. CARSON (U.S.A.)

T. YAMAMURO (Japon)

1994

MM. les Professeurs

G. KARPATI (Canada)

W.J. KOLFF (U.S.A.)

1995

MM. les Professeurs

D. WALKER (U.S.A.)

M. MULLER (Suisse)

V. BONOMINI (Italie)

1997

MM. les Professeurs

C. DINARELLO (U.S.A.)

D. STULBERG (U.S.A.)

A. MEIKLE DAVISON (Grande-Bretagne)

P.I. BRANEMARK (Suède)

1998

MM. les Professeurs

O. JARDETSKY (U.S.A.)

1999

MM. les Professeurs

J. BOTELLA LLUSIA (Espagne) 
D. COLLEN (Belgique)

S. DIMAURO (U. S. A.)

2000

MM. les Professeurs

D. SPIEGEL (U. S. A.)

C. R. CONTI (U.S.A.)

2001

MM. les Professeurs

P-B. BENNET (U. S. A.)

G. HUGUES (Grande Bretagne)

J-J. O'CONNOR (Grande Bretagne)

2002

MM. les Professeurs

M. ABEDI (Canada)

K. DAI (Chine)

2003

M. le Professeur

T. MARRIE (Canada)

Sir

G.K. RADDA (Grande Bretagne)

2004

M. le Professeur

M. DAKE (U.S.A.)

2005

M. le Professeur

L. CAVALLI-SFORZA (U.S.A.)

2006

M. le Professeur

A. R. CASTANEDA (U.S.A.)

2007

M. le Professeur

S. KAUFMANN (Allemagne) 
AGOSTINI FERRANDES Aubert

ALBANESE Jacques

ALIMI Yves

AMABILE Philippe

AMBROSI Pierre

ANDRE Nicolas

ARGENSON Jean-Noël

ASTOUL Philippe

ATTARIAN Shahram

AUDOUIN Bertrand

AUQUIER Pascal

AVIERINOS Jean-François

AZULAY Jean-Philippe

BAILLY Daniel

BARLESI Fabrice

BARLIER-SETTI Anne

BARLOGIS Vincent

BARTHET Marc

BARTOLI Christophe

BARTOLI Jean-Michel

BARTOLI Michel

BARTOLOMEI Fabrice

BASTIDE Cyrille

BENSOUSSAN Laurent

BERBIS Philippe

BERBIS Julie

BERDAH Stéphane

BEROUD Christophe

BERTUCCI François

BLAISE Didier

BLIN Olivier

BLONDEL Benjamin

BONIN/GUILLAUME Sylvie

BONELLO Laurent

BONNET Jean-Louis

BOUBLI Léon Surnombre

BOUFI Mourad

BOYER Laurent

BREGEON Fabienne

BRETELLE Florence

BROUQUI Philippe

BRUDER Nicolas

BRUE Thierry

BRUNET Philippe

BURTEY Stéphane

CARCOPINO-TUSOLI Xavier

CASANOVA Dominique

CASTINETTI Frédéric

CECCALDI Mathieu

CHAGNAUD Christophe

CHAMBOST Hervé

CHAMPSAUR Pierre

CHANEZ Pascal

CHARAFFE-JAUFFRET Emmanuelle

CHARREL Rémi

CHAUMOITRE Kathia

CHIARONI Jacques

CHINOT Olivier
CHOSSEGROS Cyrille

COLLART Frédéric

COSTELLO Régis

COURBIERE Blandine

COWEN Didier

CRAVELLO Ludovic

CUISSET Thomas

DA FONSECA David

DAHAN-ALCARAZ Laetitia

DANIEL Laurent

DARMON Patrice

DAVID Thierry

D'ERCOLE Claude

D'JOURNO Xavier

DEHARO Jean-Claude

DELAPORTE Emmanuel

DENIS Danièle

DISDIER Patrick

DODDOLI Christophe

DRANCOURT Michel

DUBUS Jean-Christophe

DUFFAUD Florence

DUFOUR Henry

DURAND Jean-Marc

DUSSOL Bertrand

EBBO Mikaël

EUSEBIO Alexandre

FABRE Alexandre

FAKHRY Nicolas

FELICIAN Olvier

FENOLLAR Florence

FIGARELLA/BRANGER Dominique

FLECHER Xavier

FOUILLOUX Virginie

FOURNIER Pierre-Edouard

FRANCESCHI Frédéric

FUENTES Stéphane

GABERT Jean

GABORIT Bénédicte

GAINNIER Marc

GARCIA Stéphane

GARIBOLDI Vlad

GAUDART Jean

GAUDY-MARQUESTE Caroline

GENTILE Stéphanie

GERBEAUX Patrick

GEROLAMI/SANTANDREA René

GILBERT/ALESSI Marie-Christine

GIORGI Roch

GIOVANNI Antoine

GIRARD Nadine

GIRAUD/CHABROL Brigitte

GONCALVES Anthony

GRANEL/REY Brigitte

GRANVAL Philippe

GREILLIER Laurent

GROB Jean-Jacques

GUEDJ Eric 
PAGANELLI Franck

PANUEL Michel Surnombre

PAPAZIAN Laurent

PAROLA Philippe

PARRATTE Sébastien Disponibilité

PELISSIER-ALICOT Anne-Laure

PELLETIER Jean

PERRIN Jeanne

PETIT Philippe

PHAM Thao

PIERCECCHI/MARTI Marie-Dominiq'

PIQUET Philippe

PIRRO Nicolas

POINSO François

RACCAH Denis

RANQUE Stéphane

RAOULT Didier Surnombre

REGIS Jean

REYNAUD/GAUBERT Martine

REYNAUD Rachel

RICHARD/LALLEMAND Marie-AlethTROPIANO Patrick

RICHIERI Raphaëlle
ROCHE Pierre-Hugues

ROCH Antoine

ROCHWERGER Richard

ROLL Patrice

ROSSI Dominique

ROSSI Pascal

ROUDIER Jean

SALAS Sébastien

SARLON-BARTOLI Gabrielle

SCAVARDA Didier

SCHLEINITZ Nicolas

SEBAG Frédéric

SIELEZNEFF Igor

SIMON Nicolas

STEIN Andréas

TAIEB David

THOMAS Pascal

THUNY Franck

TREBUCHON-DA FONSECA Agnès

TRIGLIA Jean-Michel

TSIMARATOS Michel

\title{
PROFESSEUR DES UNIVERSITES
}

\author{
ADALIAN Pascal \\ AGHABABIAN Valérie \\ BELIN Pascal \\ CHABANNON Christian \\ CHABRIERE Eric \\ FERON François \\ LE COZ Pierre \\ LEVASSEUR Anthony \\ RANJEVA Jean-Philippe \\ SOBOL Hagay \\ PROFESSEUR CERTIFIE
}

BRANDENBURGER Chantal retraite mars 2021

FRAISSE-MANGIALOMINI Jeanne

PROFESSEUR DES UNIVERSITES ASSOCIE à MI

REVIS Joana

PROFESSEUR DES UNIVERSITES MEDECINE GEN

GENTILE Gaëtan

PROFESSEUR ASSOCIE DE MEDECINE GENERALE . 


\section{GUIEU Régis}

GUIS Sandrine

GUYE Maxime

GUYOT Laurent

GUYS Jean-Michel Surnombre

HABIB Gilbert

HARDWIGSEN Jean

HARLE Jean-Robert

HOUVENAEGHEL Gilles

JACQUIER Alexis

JOURDE-CHICHE Noémie

JOUVE Jean-Luc

KAPLANSKI Gilles

KARSENTY Gilles

KERBAUL François détachement

KRAHN Martin

LAFFORGUE Pierre

LAGIER Jean-Christophe

LAMBAUDIE Eric

LANCON Christophe

LA SCOLA Bernard

LAUNAY Franck

LAVIEILLE Jean-Pierre

LE CORROLLER Thomas

LECHEVALLIER Eric

LEGRE Régis

LEHUCHER-MICHEL Marie-Pascale

LEONE Marc

LEONETTI Georges

LEPIDI Hubert

LEVY Nicolas

MACE Loïc

MAGNAN Pierre-Edouard

MANCINI Julien

MEGE Jean-Louis

MERROT Thierry

METZLER/GUILLEMAIN Catherine

MEYER/DUTOUR Anne

MICCALEF/ROLL Joëlle

MICHEL Fabrice

MICHEL Gérard

MICHEL Justin

MICHELET Pierre

MILH Mathieu

MILLION Matthieu

MOAL Valérie

MORANGE Pierre-Emmanuel

MOULIN GuY

MOUTARDIER Vincent

NAUDIN Jean

NICOLAS DE LAMBALLERIE Xavier

NICOLLAS Richard

NGUYEN Karine

OLIVE Daniel

OLLIVIER Matthieu

OUAFIK L'Houcine

OVAERT-REGGIO Caroline

PADOVANI Laetitia 
TURRINI Olivier

VALERO René

VAROQUAUX Arthur Damien

VELLY Lionel

VEY Norbert

VIDAL Vincent

VIENS Patrice

VILLANI Patrick

VITON Jean-Michel

VITTON Véronique

VIEHWEGER Heide Elke détachement

VIVIER Eric

XERRI Luc 


\begin{tabular}{|c|c|}
\hline AHERFI Sarah & ELDIN Carole \\
\hline ANGELAKIS Emmanouil (disponibilité) & FAURE Alice \\
\hline ATLAN Catherine (disponibilité) & FOLETTI Jean- Marc \\
\hline BEGE Thierry & FRANKEL Diane \\
\hline BELIARD Sophie & FROMONOT Julien \\
\hline BENYAMINE Audrey & GASTALDI Marguerite \\
\hline BERTRAND Baptiste & GELSI/BOYER Véronique \\
\hline BEYER-BERJOT Laura & GIUSIANO Bernard \\
\hline BIRNBAUM David & GIUSIANO COURCAMBECK Sophie \\
\hline BONINI Francesca & GONZALEZ Jean-Michel \\
\hline BOUCRAUT Joseph & GOURIET Frédérique \\
\hline BOULAMERY Audrey & GRAILLON Thomas \\
\hline BOULLU/CIOCCA Sandrine & GUERIN Carole \\
\hline BOUSSEN Salah Michel & GUENOUN MEYSSIGNAC Daphné \\
\hline BUFFAT Christophe & GUIDON Catherine \\
\hline CAMILLERI Serge & GUIVARCH Jokthan \\
\hline CARRON Romain & HAUTIER/KRAHN Aurélie \\
\hline CASSAGNE Carole & HRAIECH Sami \\
\hline CERMOLACCE Michel & KASPI-PEZZOLI Elise \\
\hline CHAUDET Hervé & L'OLLIVIER Coralie \\
\hline CHRETIEN Anne-Sophie & LABIT-BOUVIER Corinne \\
\hline COZE Carole & LAFAGE/POCHITALOFF-HUVALE Marina \\
\hline CUNY Thomas & LAGARDE Stanislas \\
\hline DADOUN Frédéric (disponibilité) & LAGIER Aude (disponibilité) \\
\hline DALES Jean-Philippe & LAGOUANELLE/SIMEONI Marie-Claude \\
\hline DARIEL Anne & LEVY/MOZZICONACCI Annie \\
\hline DAUMAS Aurélie & LOOSVELD Marie \\
\hline DEGEORGES/VITTE Joëlle & MAAROUF Adil \\
\hline DELLIAUX Stéphane & MACAGNO Nicolas \\
\hline DESPLAT/JEGO Sophie & MAUES DE PAULA André \\
\hline DEVILLIER Raynier & MEGE Diane \\
\hline DUBOURG Grégory & MOTTOLA GHIGO Giovanna \\
\hline DUCONSEIL Pauline & NINOVE Laetitia \\
\hline DUFOUR Jean-Charles & NOUGAIREDE Antoine \\
\hline
\end{tabular}

PAULMYER/LACROIX Odile

PESENTI Sébastien

RADULESCO Thomas

RESSEGUIER Noémie

ROBERT Philippe

ROBERT Thomas

ROMANET Pauline

SABATIER Renaud

SARI-MINODIER Irène

SAVEANU Alexandru

SECQ Véronique (disponibilité)

STELLMANN Jan-Patrick

SUCHON Pierre

TABOURET Emeline

TOGA Caroline

TOGA Isabelle

TOMASINI Pascale

TOSELLO Barthélémy

TROUSSE Delphine

TUCHTAN-TORRENTS Lucile

VELY Frédéric

VION-DURY Jean

ZATTARA/CANNONI Hélène

\section{MAITRES DE CONFERENCES DES UNIVERSITES}

(mono-appartenants)
ABU ZAINEH Mohammad
BARBACARU/PERLES T. A.
BERLAND Caroline
BOYER Sylvie
COLSON Sébastien
DEGIOANNI/SALLE Anna

DESNUES Benoît

MARANINCHI Marie

MERHEJ/CHAUVEAU Vicky

MINVIELLE/DEVICTOR Bénédicte

POGGI Marjorie

POUGET Benoît
RUEL Jérôme

THOLLON Lionel

THIRION Sylvie

VERNA Emeline

MAITRE DE CONFERENCES DES UNIVERSITES DE MEDECINE GENERALE

CASANOVA Ludovic

MAITRES DE CONFERENCES ASSOCIES DE MEDECINE GENERALE à MI-TEMPS

BARGIER Jacques

CALVET-MONTREDON Céline

FORTE Jenny

JANCZEWSKI Aurélie

NUSSLI Nicolas

ROUSSEAU-DURAND Raphaëlle 
THERY Didier

MAITRE DE CONFERENCES ASSOCIE à MI-TEMPS

BOURRIQUEN Maryline

EVANS-VIALLAT Catherine

LAZZAROTTO Sébastien

LUCAS Guillaume

MATHIEU Marion

MAYENS-RODRIGUES Sandrine

MELLINAS Marie

ROMAN Christophe

TRINQUET Laure 
ESSEURS DES UNIVERSITES et MAITRES DE CONFERENCES DES UNIVERSITES - PRATICIENS HOSPITA| PROFESSEURS ASSOCIES, MAITRES DE CONFERENCES DES UNIVERSITES mono-appartenants

\section{ANATOMIE 4201}

CHAMPSAUR Pierre (PU-PH)

LE CORROLLER Thomas (PU-PH)

PIRRO Nicolas (PU-PH)

GUENOUN-MEYSSIGNAC Daphné (MCU-PH)

LAGIER Aude (MCU-PH) disponibilité

THOLLON Lionel (MCF) (60ème section)
ANTHROPOLOGIE 20

ADALIAN Pascal (PR)

DEGIOANNI/SALLE Anna (MCF)

POUGET Benoît (MCF)

VERNA Emeline (MCF)

BACTERIOLOGIE-VIROLOGIE ; HYGIENE HOSPITALIERE 4501

CHARREL Rémi (PU PH)

DRANCOURT Michel (PU-PH)

FENOLLAR Florence (PU-PH)

FOURNIER Pierre-Edouard (PU-PH)

ANATOMIE ET CYTOLOGIE PATHOLOGIQUES 4203

CHARAFE/JAUFFRET Emmanuelle (PU-PH)

ICOLAS DE LAMBALLERIE Xavier (PU-PH)

LA SCOLA Bernard (PU-PH)

RAOULT Didier (PU-PH) Surnombre

AHERFI Sarah (MCU-PH)

ANGELAKIS Emmanouil (MCU-PH) disponibilité

DUBOURG Grégory (MCU-PH)

GOURIET Frédérique (MCU-PH)

NOUGAIREDE Antoine (MCU-PH)

NINOVE Laetitia (MCU-PH)

DALES Jean-Philippe (MCU-PH)

GIUSIANO COURCAMBECK Sophie (MCU PH)

LABIT/BOUVIER Corinne (MCU-PH)

CHABRIERE Eric (PR) (64ème section)

MACAGNO Nicolas (MCU-PH)

MAUES DE PAULA André (MCU-PH)

SECQ Véronique (MCU-PH) disponibilité

LEVASSEUR Anthony (PR) (64ème section)

DESNUES Benoit (MCF) ( 65ème section )

MERHEJ/CHAUVEAU Vicky (MCF) (87ème section)

BIOCHIMIE ET BIOLOGIE MOLECULAIRE 4401

ANESTHESIOLOGIE ET REANIMATION CHIRURGICALE ; MEDECINE URGENCE 4801

ALBANESE Jacques (PU-PH)

BRUDER Nicolas (PU-PH)

LEONE Marc (PU-PH)

MICHEL Fabrice (PU-PH)

VELLY Lionel (PU-PH)

BOUSSEN Salah Michel (MCU-PH)

GUIDON Catherine (MCU-PH)

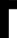
BARLIER/SETTI Anne (PU-PH)

GABERT Jean (PU-PH)

GUIEU Régis (PU-PH)

OUAFIK L'Houcine (PU-PH)

BUFFAT Christophe (MCU-PH)

FROMONOT Julien (MCU-PH)

MOTTOLA GHIGO Giovanna (MCU-PH)

ROMANET Pauline (MCU-PH)

SAVEANU Alexandru (MCU-PH)

\section{ANGLAIS 11}

\section{BIOLOGIE CELLULAIRE 4403}

BRANDENBURGER Chantal (PRCE) retraite mars 2021

FRAISSE-MANGIALOMINI Jeanne (PRCE)
ROLL Patrice (PU-PH)

FRANKEL Diane (MCU-PH)

GASTALDI Marguerite (MCU-PH)

KASPI-PEZZOLI Elise (MCU-PH)

LEVY-MOZZICONNACCI Annie (MCU-PH)

ET DE LA REPRODUCTION ; GYNECOLOGIE MEDICALE 5405

METZLER/GUILLEMAIN Catherine (PU-PH)

PERRIN Jeanne (PU-PH) 
BELIN Pascal (PR) (69ème section)

RANJEVA Jean-Philippe (PR) (69ème section)

CAMMILLERI Serge (MCU-PH)

VION-DURY Jean (MCU-PH)

BARBACARU/PERLES Téodora Adriana (MCF) (69ème section)
DEHARO Jean-Claude (PU-PH)

FRANCESCHI Frédéric (PU-PH)

HABIB Gilbert (PU-PH)

PAGANELLI Franck (PU-PH)

THUNY Franck (PU-PH)
BIOSTATISTIQUES, INFORMATIQUE MEDICALE ET TECHNOLOGIES DE COMMUNICATION 4604

GAUDART Jean (PU-PH)

GIORGI Roch (PU-PH)

MANCINI Julien (PU-PH)

CHAUDET Hervé (MCU-PH)

DUFOUR Jean-Charles (MCU-PH)

GIUSIANO Bernard (MCU-PH)

ABU ZAINEH Mohammad (MCF) (5ème section)

BOYER Sylvie (MCF) (5ème section)

\section{CHIRURGIE VISCERALE ET DIGESTIVE 5202}

BERDAH Stéphane (PU-PH) HARDWIGSEN Jean (PU-PH) MOUTARDIER Vincent (PU-PH) SEBAG Frédéric (PU-PH) SIELEZNEFF Igor (PU-PH) TURRINI Olivier (PU-PH)

BEGE Thierry (MCU-PH)

BEYER-BERJOT Laura (MCU-PH)

BIRNBAUM David (MCU-PH)

DUCONSEIL Pauline (MCU-PH)

GUERIN Carole (MCU PH)

MEGE Diane (MCU-PH)

\section{CHIRURGIE ORTHOPEDIQUE ET TRAUMATOLOGIQUE 5002}

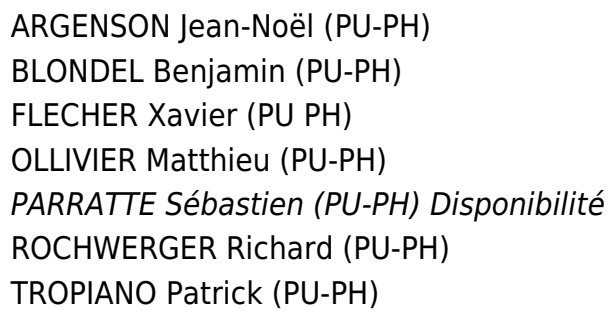

\section{CHIRURGIE INFANTILE 5402CHIRURGIE INFANTILE 5402}

GUYS Jean-Michel (PU-PH) Surnombre

JOUVE Jean-Luc (PU-PH)

LAUNAY Franck (PU-PH)

MERROT Thierry (PU-PH)

VIEHWEGER Heide Elke (PU-PH) détachement

DARIEL Anne (MCU-PH)

FAURE Alice (MCU PH)

PESENTI Sébastien (MCU-PH)

FACIALE ET STOMATOLOGIE 5503CHIRURGIE MAXILLO-FACIALE

CHOSSEGROS Cyrille (PU-PH)

GUYOT Laurent (PU-PH)

FOLETTI Jean-Marc (MCU-PH) 
COLLART Frédéric (PU-PH)

D'JOURNO Xavier (PU-PH)

CASANOVA Dominique (PU-PH)

DODDOLI Christophe (PU-PH)

LEGRE Régis (PU-PH)

FOUILLOUX Virginie (PU-PH)

BERTRAND Baptiste (MCU-PH)

GARIBOLDI Vlad (PU-PH)

HAUTIER/KRAHN Aurélie (MCU-PH)

MACE LoÏc (PU-PH)

THOMAS Pascal (PU-PH)

TROUSSE Delphine (MCU-PH)

CHIRURGIE VASCULAIRE ; MEDECINE VASCULAIRE 5104

\author{
ALIMI Yves (PU-PH) \\ AMABILE Philippe (PU-PH) \\ BARTOLI Michel (PU-PH) \\ BOUFI Mourad (PU-PH) \\ MAGNAN Pierre-Edouard (PU-PH) \\ PIQUET Philippe (PU-PH) \\ SARLON-BARTOLI Gabrielle (PU PH)
}

GASTROENTEROLOGIE ; HEPATOLOGIE ; ADDICTOLOGIE 5201

BARTHET Marc (PU-PH)

DAHAN-ALCARAZ Laetitia (PU-PH)

GEROLAMI-SANTANDREA René (PU-PH)

GRANDVAL Philippe (PU-PH)

VITTON Véronique (PU-PH)

HISTOLOGIE, EMBRYOLOGIE ET CYTOGENETIQUE 4202

LEPIDI Hubert (PU-PH)

PAULMYER/LACROIX Odile (MCU-PH)

GONZALEZ Jean-Michel ( MCU-PH)

DERMATOLOGIE - VENEREOLOGIE 5003

BERBIS Philippe (PU-PH)

DELAPORTE Emmanuel (PU-PH)

GAUDY/MARQUESTE Caroline (PU-PH)

GROB Jean-Jacques (PU-PH)

RICHARD/LALLEMAND Marie-Aleth (PU-PH)

\section{GENETIQUE 4704}

BEROUD Christophe (PU-PH)

KRAHN Martin (PU-PH)

LEVY Nicolas (PU-PH)

NGYUEN Karine (PU-PH)

TOGA Caroline (MCU-PH)

ZATTARA/CANNONI Hélène (MCU-PH)

GYNECOLOGIE-OBSTETRIQUE ; GYNECOLOGIE MEDICALE 5403

AGOSTINI Aubert (PU-PH)

BOUBLI Léon (PU-PH) Surnombre

BRETELLE Florence (PU-PH)

CARCOPINO-TUSOLI Xavier (PU-PH)

COURBIERE Blandine (PU-PH)

CRAVELLO Ludovic (PU-PH)

D'ERCOLE Claude (PU-PH)

BRUE Thierry (PU-PH)

CASTINETTI Frédéric (PU-PH)

CUNY Thomas (MCU PH) 


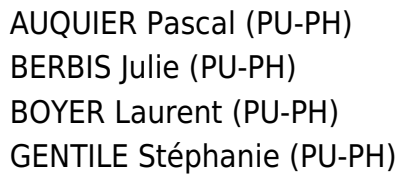

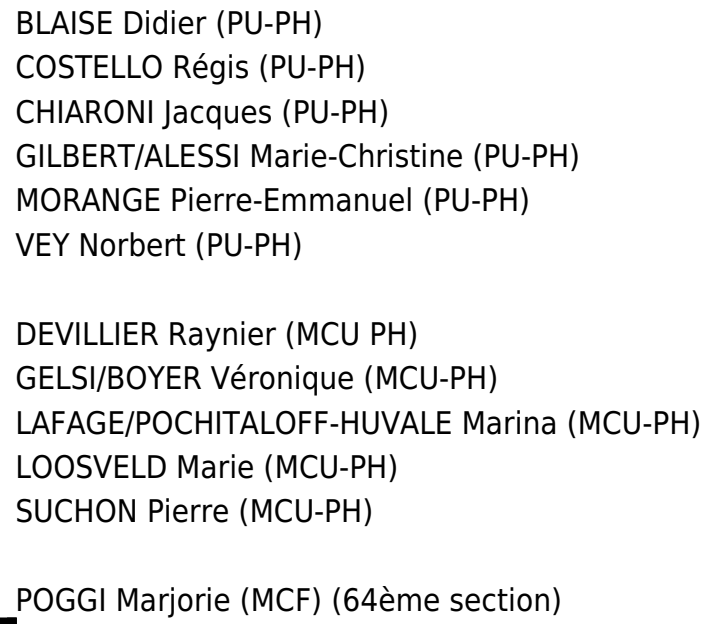

\section{MEDECINE PHYSIQUE ET DE READAPTATION 4905}

\section{MALADIES INFECTIEUSES ; MALADIES TROPICALES 4503}

BROUQUI Philippe (PU-PH)

LAGIER Jean-Christophe (PU-PH)

MILLION Matthieu (PU-PH)

PAROLA Philippe (PU-PH)

STEIN Andréas (PU-PH)

ELDIN Carole (MCU-PH)

\section{MEDECINE ET SANTE AU TRAVAIL 4602}

LEHUCHER/MICHEL Marie-Pascale (PU-PH)

\section{MEDECINE INTERNE ; GERIATRIE ET BIOLOGIE DU VIEILLISSEMENT ; ADDICTOLOGIE 5301}

BONIN/GUILLAUME Sylvie (PU-PH)

DISDIER Patrick (PU-PH)

DURAND Jean-Marc (PU-PH)

EBBO Mikael (PU-PH)

GRANEL/REY Brigitte (PU-PH)

HARLE Jean-Robert (PU-PH)

ROSSI Pascal (PU-PH)

SCHLEINITZ Nicolas (PU-PH) 

GENTILE Gaëtan (PR Méd. Gén. Temps plein)
BRUNET Philippe (PU-PH)
BURTEY Stépahne (PU-PH)
CASANOVA Ludovic (MCF Méd. Gén. Temps plein)
DUSSOL Bertrand (PU-PH)
JOURDE CHICHE Noémie (PU PH)

GUIDA Pierre (PR associé Méd. Gén. à mi-temps) retraite au 25/09/2(MOAL Valérie (PU-PH)

BARGIER Jacques (MCF associé Méd. Gén. À mi-temps)

ROBERT Thomas (MCU-PH)

CALVET-MONTREDON Céline (MCF associé Méd. Gén. à temps plein)

FORTE Jenny (MCF associé Méd. Gén. À mi-temps)

JANCZEWSKI Aurélie (MCF associé Méd. Gén. À mi-temps)

NUSSLI Nicolas (MCF associé Méd. Gén. À mi-temps)

NEUROCHIRURGIE 4902

ROUSSEAU-DURAND Raphaëlle (MCF associé Méd. Gén. À mi-temps) DUFOUR Henry (PU-PH)

THERY Didier (MCF associé Méd. Gén. À mi-temps) (nomination au 1,FUENTES Stéphane (PU-PH)

\section{NUTRITION 4404}

REGIS Jean (PU-PH)

DARMON Patrice (PU-PH)

RACCAH Denis (PU-PH)

ROCHE Pierre-Hugues (PU-PH)

SCAVARDA Didier (PU-PH)

VALERO René (PU-PH)

CARRON Romain (MCU PH)

GRAILLON Thomas (MCU PH)

ATLAN Catherine (MCU-PH) disponibilité

BELIARD Sophie (MCU-PH)

MARANINCHI Marie (MCF) (66ème section)

\section{ONCOLOGIE 65 (BIOLOGIE CELLULAIRE)}

CHABANNON Christian (PR) (66ème section)

SOBOL Hagay (PR) (65ème section)

\section{OPHTALMOLOGIE 5502}

DAVID Thierry (PU-PH)

DENIS Danièle (PU-PH)

DESSI Patrick (PU-PH)

FAKHRY Nicolas (PU-PH)

GIOVANNI Antoine (PU-PH)

LAVIEILLE Jean-Pierre (PU-PH)

MICHEL Justin (PU-PH)

NICOLLAS Richard (PU-PH)

TRIGLIA Jean-Michel (PU-PH)

RADULESCO Thomas (MCU-PH)

REVIS Joana (PAST) (Orthophonie) (7ème Section)

\section{NEUROLOGIE 4901}

ATTARIAN Sharham (PU PH)

AUDOIN Bertrand (PU-PH)

AZULAY Jean-Philippe (PU-PH)

CECCALDI Mathieu (PU-PH)

EUSEBIO Alexandre (PU-PH)

FELICIAN Olivier (PU-PH)

PELLETIER Jean (PU-PH)

MAAROUF Adil (MCU-PH)

\section{PEDOPSYCHIATRIE; ADDICTOLOGIE 4904}

DA FONSECA David (PU-PH)

POINSO François (PU-PH)

GUIVARCH Jokthan (MCU-PH)

\section{PHARMACOLOGIE CLINIQUE; ADDICTOLOGIE 4803}

\author{
BLIN Olivier (PU-PH) \\ MICALLEF/ROLL Joëlle (PU-PH) \\ SIMON Nicolas (PU-PH)
}

BOULAMERY Audrey (MCU-PH) 


\section{ANDRE Nicolas (PU-PH)}

BARLOGIS Vincent (PU-PH)

CHAMBOST Hervé (PU-PH)

DUBUS Jean-Christophe (PU-PH)

FABRE Alexandre (PU-PH)

GIRAUD/CHABROL Brigitte (PU-PH)

MICHEL Gérard (PU-PH)

MILH Mathieu (PU-PH)

OVAERT-REGGIO Caroline (PU-PH)

REYNAUD Rachel (PU-PH)

TSIMARATOS Michel (PU-PH)

TOSELLO Barthélémy (MCU-PH)

\section{PHYSIOLOGIE 4402}

BARTOLOMEI Fabrice (PU-PH)

BREGEON Fabienne (PU-PH)

GABORIT Bénédicte (PU-PH)

MEYER/DUTOUR Anne (PU-PH)

TREBUCHON/DA FONSECA Agnès (PU-PH)

BONINI Francesca (MCU-PH)

BOULLU/CIOCCA Sandrine (MCU-PH)

DADOUN Frédéric (MCU-PH) (disponibilité)

DELLIAUX Stéphane (MCU-PH)

LAGARDE Stanislas (MCU-PH)

RUEL Jérôme (MCF) (69ème section)

THIRION Sylvie (MCF) (66ème section)

\section{PSYCHIATRIE D'ADULTES ; ADDICTOLOGIE 4903}

\section{BAILLY Daniel (PU-PH)}

LANCON Christophe (PU-PH)

NAUDIN Jean (PU-PH)

RICHIERI Raphaëlle (PU-PH)

CERMOLACCE Michel (MCU-PH)

\section{PNEUMOLOGIE; ADDICTOLOGIE 5101}

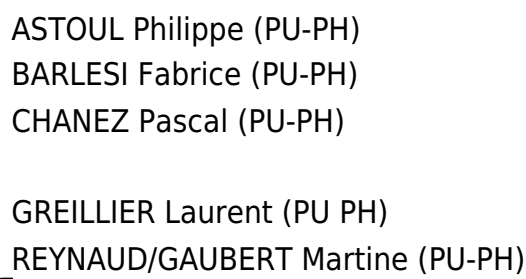

\section{6}

TOMASINI Pascale (MCU-PH)

AGHABABIAN Valérie (PR)

LAZZAROTTO Sébastien (MAST)

\section{RADIOLOGIE ET IMAGERIE MEDICALE 4302}

BARTOLI Jean-Michel (PU-PH)

CHAGNAUD Christophe (PU-PH)

CHAUMOITRE Kathia (PU-PH)

GIRARD Nadine (PU-PH)

JACQUIER Alexis (PU-PH)

MOULIN Guy (PU-PH)

PANUEL Michel (PU-PH) surnombre

PETIT Philippe (PU-PH)

VAROQUAUX Arthur Damien (PU-PH)

VIDAL Vincent (PU-PH)

STELLMANN Jan-Patrick (MCU-PH)

\section{RHUMATOLOGIE 5001}

GUIS Sandrine (PU-PH)

LAFFORGUE Pierre (PU-PH)

PHAM Thao (PU-PH)

ROUDIER Jean (PU-PH)

THERAPEUTIQUE; MEDECINE D'URGENCE; ADDICTOLOGIE 480.

AMBROSI Pierre (PU-PH)

VILLANI Patrick (PU-PH)

DAUMAS Aurélie (MCU-PH) 
GAINNIER Marc (PU-PH) GERBEAUX Patrick (PU-PH)

PAPAZIAN Laurent (PU-PH)

$\mathrm{ROCH}$ Antoine (PU-PH)

HRAIECH Sami (MCU-PH)
BASTIDE Cyrille (PU-PH)

KARSENTY Gilles (PU-PH)

LECHEVALLIER Eric (PU-PH)

ROSSI Dominique (PU-PH) 


\section{Remerciements}

\section{Aux membres du jury,}

A Monsieur le Professeur Fabrice BARLESI,

Merci d'avoir accepté de présider ce jury et de m'avoir permis de réaliser ce travail. Merci de m'avoir convaincu dès le début de mon internat que cette voie était la mienne, je suis sûre de ne jamais regretter ce choix. Merci pour votre rigueur bienveillante qui me pousse à faire toujours mieux, en sachant que la route est encore longue pour approcher votre excellence. J'admire le médecin, le chercheur, l'enseignant et le chef que vous êtes, et vous resterez même de loin une source d'inspiration quotidienne pour moi. Merci de me faire confiance et de m'avoir ouvert tant de portes, soyez sûr que j'ai conscience de ma chance, mais également de mes responsabilités. Je suis fière d'être votre élève, et je vous promets d'en être digne.

\section{A Monsieur le Professeur Laurent GREILLIER,}

Merci d'avoir accepté de juger ce travail. Merci pour ta bienveillance et ton enseignement précieux depuis le début de mon internat. J'admire ton calme et ta diplomatie qui désamorcent toutes les situations et qui nous permettent d'avoir la meilleure formation possible, je suis certaine que ces qualités te permettront d'écrire la pneumologie marseillaise de demain. Je suis très heureuse de rejoindre ton équipe, merci de m'y accueillir si chaleureusement, j'espère pouvoir profiter encore longtemps de ton expertise dans tant de domaines.

\section{A Monsieur le Professeur François BERTUCCI,}

Merci d'avoir accepté de juger ce travail et pour votre aide précieuse. Merci de m'avoir ouvert la porte du laboratoire d'oncologie prédictive l'année dernière, j'ai eu beaucoup de chance de pouvoir travailler dans cette équipe que j'admire énormément. J'espère que cette collaboration se poursuivra longtemps et que nous aurons encore de nombreux projets en commun.

\section{A Madame le Docteur Pascale TOMASINI,}

Merci d'avoir accepté de diriger ce travail, mais surtout pour tout le reste. Merci de m'avoir pris par la main dès le début de mon internat sans jamais me lâcher depuis. Merci pour ton encadrement toujours parfait, qui a su évoluer avec moi, et me donner l'envie et la force de me lancer dans ce parcours. Merci d'exister pour me prouver tous les jours qu'il est possible de tout mener de front de façon excellente, en étant une femme et le tout en talons aiguilles. Le médecin que je deviens aujourd'hui et l'universitaire que j'espère devenir demain te devront tant. Plus qu'un modèle, tu es devenue mon maitre, et je suis si fière d'être ton élève.

\section{A toutes les équipes qui ont rendu possible la réalisation de ce travail,}

Merci à Unicancer et à tous les centres ayant inclus des patients dans l'essai SAFIR-02 Lung de m'avoir permis de disposer de données de grande qualité.

Merci à l'équipe de biostatistiques de l'Institut Gustave Roussy et à l'équipe de génétique de l'Institut Curie du Professeur Ivan BIECHE pour m'avoir aidé dans I'analyse des données avec pédagogie et bienveillance. 


\section{A ma famille,}

\section{A mes parents,}

Merci pour votre soutien sans faille pendant ces longues années, je sais à quel point ça a pu être difficile pour vous de $\mathrm{m}$ 'accompagner dans ce monde qui vous est inconnu, mais soyez surs que vous avez été parfaits. Merci de m'avoir transmis les valeurs de travail, d'effort et d'excellence qui me permettent de réaliser un de mes rêves aujourd'hui, merci d'avoir toujours cru en moi et de ne jamais avoir mis de limite à mes ambitions. Pardon d'être souvent trop dure, sachez que je vous aime plus que tout et que je suis très fière de vous.

\section{A Aymeric,}

Mon grand grand frère, merci de ne jamais avoir douté que ce jour arrive, merci pour ton éternelle sérénité face à la vie qui tempère mes angoisses. Malgré nos caractères bien différents, je suis fière de l'homme que tu es devenu et je sais que l'inverse est vraie aussi.

Cindy, merci d'être entrée dans nos vies, je suis très heureuse que tu fasses partie de la famille.

\section{A mes grands-parents,}

Merci d'avoir toujours été là pour moi et de m’avoir soutenu pendant ces longues années. Merci pour votre amour et pour vos valeurs, merci d'être toujours un modèle pour moi.

\section{A mes oncles, tantes, cousins et cousine,}

Merci à tous pour votre soutien pendant toutes ces années, merci de vous être toujours intéressés à mon parcours et d'avoir compris mes absences. J'ai de la chance de vous avoir dans ma vie.

\section{A mes amis,}

Valentine, merci pour cette amitié si précieuse et solide qui dure depuis nos 6 ans. Merci d'être là pour toutes les crises et toutes les joies, merci de me comprendre comme personne, merci de m'avoir tant soutenue pendant ces années de médecine que tu as vécu deux fois sans rien demander.

Florent, merci de me pousser vers le haut et me soutenir depuis toutes ces années. Merci de comprendre et nourrir mon ambition, merci d'être ma base sécurisante au quotidien. Je suis si fière de ton parcours, imagine quand on sera là pour ta thèse à toi dans quelques années. Merci de m'aimer comme ça, en nous rendant plus forts et pour toujours.

Pauline, merci pour tous ces beaux souvenirs et tous les beaux moments à venir, merci d'être toujours là pour moi quoi qu'il se passe, merci de partager et comprendre bon nombre de mes névroses, tu n'imagines pas comme c'est important de se sentir comprise et soutenue. J'ai tellement hâte que vous arriviez et de pouvoir profiter de toi au quotidien. 
Jeanne, merci d’avoir toujours été là, merci pour tes délices, merci d’être notre mère. Merci d'avoir été aussi impliquée pendant toutes ces années, quelle joie de toujours être le meilleur docteur du monde à tes yeux.

Laura, quel bonheur d'avoir fait ce parcours à tes côtés depuis le début, d'avoir partagé les bons moments comme les difficultés, merci pour ces innombrables souvenirs, merci de faire partie de ma vie, tu n'imagines pas à quel point tu comptes pour moi.

Léa, que de différences mais que d'amour, merci de toujours autant me faire rire, merci de rendre tous les moments qu'on passe ensemble mémorables, merci de te moquer du moi trop précieux et non adaptable. Tu peux compter sur moi pour les travaux du camion et les semaines sans douche, juste pas tout de suite.

Sonia, merci d'avoir été la meilleure coloc du monde pendant ces 6 mois parisiens pas toujours évidents, merci d'avoir supporté ma maniaquerie, merci de m'avoir ouvert à des mondes inconnus et improbables, qu'est-ce qu'on s'est marrées quand même. Merci de partager et comprendre mon amour pour l'excellence, les concours et la fonction publique, Madame l’ambassadeur, ou Madame le Préfet, ou Docteur, comme il te plaira.

Nicolas, merci pour ton soutien, ta gentillesse et surtout pour ta science et ton féminisme sans limites. Merci de rendre Pauline heureuse.

Thibaut, merci d'être toujours là pour partager les histoires de l'hôpital, m'écouter râler, même contre les urgentistes, merci d'être si drôle, merci d'être sincère et sensible, merci d'être mauvais perdant comme moi. Tu n'imagines pas comme je suis heureuse que Valentine t'ait choisi, je ne pouvais pas rêver mieux pour elle.

Jérémy, Victor, Samuel, Mia et tous les autres, merci pour votre soutien, merci de me faire rire, merci d'exister.

\section{A mes amies de médecine,}

Roxane, merci d'avoir été là dans tous les moments bons ou difficiles ces dernières années, merci de tant me ressembler et me comprendre. Que de moments partagés, que de rigolade, que d'émotions, que de Céline, que de moments improbables au labo. Merci d'exister, ces années n'auraient pas eu la même saveur sans toi.

Marion, notre rayon de soleil, merci d'irradier de bonheur et de bienveillance chaque moment de cette vie, merci d'être toujours là quand on en a besoin, merci de toujours me demander conseil en fringues comme si j'étais Victoria Beckham. Et surtout merci pour ce beau cadeau qui arrivera dans quelques mois et que toutes ses tatas ont hâte de choyer, quel bonheur.

Doriane, merci de nous toujours nous faire rire, merci d'être toujours partante pour tout, merci de nous faire profiter de cette petite folie des psychiatres qui fait tout ton charme, merci d'aider toutes ces jeunes filles qui ont besoin de toi, tu sais comme ça me tient à cœur. 
Clémence, merci d'être si forte et de réussir à tout mener de front comme tu le fais, en étant toujours la même quand on est avec toi. On est très fières de toi et impressionnées par ton parcours, mais n'oublies surtout pas de prendre soin de toi, comptes sur nous pour toujours te le rappeler.

Julie, merci d’être encore là malgré la distance et les années, je sais que je peux compter sur toi et inversement.

\section{A la pneumologie marseillaise, cette belle famille,}

Laura, mon binôme, quelle chance d'avoir croisé ta route pour vivre cet internat. On peut sembler très différentes mais finalement on a la même vision de la vie et de notre métier, ça nous a suffi pour tout traverser main dans la main, les moments de bonheur comme les pires épreuves. Je ne doute pas que notre amitié dure, et j'espère aussi notre collaboration.

Kim, merci pour ta douceur et ton écoute, merci d'être un si bon médecin et une chercheuse si brillante, tu m'as beaucoup appris et inspiré et j'ai de la chance de t'avoir comme amie.

Youssef, merci d'avoir toujours été là pour moi, merci de poser sur moi ce regard qui rend capable de tout, j'espère que tu feras toujours partie de ma vie.

Solène, merci pour tous ces bons moments partagés, ta bonne humeur et ta bienveillance, merci de m'avoir beaucoup préservé ces deux dernières années, je suis très admirative de ton parcours, j'espère pouvoir être à ta hauteur.

Mathieu, merci pour ta gentillesse, merci pour ce calme légendaire, souvent mal interprété mais que j'admire tant. Merci de partager mon amour pour la Guinness et d'essayer de me convaincre d'aller dans des pubs sordides pour en trouver.

Julien, merci pour ta bonne humeur et ton dynamisme, merci d'être infatigable et toujours motivé, merci de m'accompagner dans ce projet universitaire, ça me rassure que tu passes toujours avant moi. J'espère qu'on pourra travailler ensemble longtemps dans de bonnes conditions, je suis sûre que l'on fera ce qu'il faut.

Éléonore, merci pour ta fraicheur et ta bonne humeur, merci de garder ton âme d'enfant qui te rend si attachante, merci pour ces beaux voyages et ces beaux souvenirs. Je suis contente de t'avoir comme amie et j'ai hâte de t'avoir comme collègue, on va se la régaler.

Jessica, merci pour ta sensibilité et ta gentillesse, merci de nous avoir rappelé à tous à quel point l'équilibre est fragile dans ce qu'on vit et à quel point il est important de prendre soin les uns des autres. Je suis heureuse que tu ailles bien, tu seras un excellent médecin. 
Fanny, Valerian, Diane, mes réunionnais préférés, j'ai eu de la chance de croiser votre route et de profiter de votre bienveillance et de vos sourires. Tous les moments passés avec vous sont géniaux, merci de toujours me rappeler où est l'essentiel. Je vous promets que dans ma prochaine vie je viens vivre chez vous.

A tous les autres, Nicolas, Bertrand, Eloi, Camille, Julie, Inès, Arnaud, Romain, JBR, JBL, François, Jules, Lyria, Manon, Marjorie, Marie, Quentin, Thibaut et tous les nouveaux, c'est toujours un bonheur de travailler avec vous et de passer de bons moments ensemble hors de l'hôpital, on a de la chance d'être soudés et de beaucoup s'aider et je suis sûre que les plus jeunes sauront faire vivre cette bonne ambiance.

Mathilda, la plus fidèle interne du $8^{\text {ème, }}$ tu fais partie de la team, on a beaucoup de chance de t'avoir, à l'hôpital comme au bar.

\section{A toutes les personnes que j'ai pu rencontrer pendant mon internat,}

A toute la pneumologie de l'hôpital Nord, où j'ai fait mes premiers pas et où je me sens chez moi. Merci à Gaëlle, Manue, Odile et Véronique pour votre écoute et vos précieux conseils quand j'étais toute petite, merci de m'avoir si bien accueillie et donné envie de revenir. Merci au Professeur Pascal Chanez de m'avoir fait confiance, de toujours être de bon conseil et de m'avoir encouragé dans mes projets. Merci à Laurie de prendre soin de Laura, merci à Marion pour ta bienveillance, à Alain pour ta patience et ta gentillesse, j'ai aimé travailler avec vous tous. Merci à Hervé pour ta bonne humeur et ton expertise, merci de ne pas avoir désespéré de mon absence de dextérité, merci aux infirmières du 8ème d'être si douées.

Merci au service de pneumologie du CH d'Aix en Provence, Marie, Stéphanie et Xavier, vous savez que j'ai adoré apprendre auprès de vous et que vous garderez une place particulière pour moi.

Merci à toute l'équipe de la réanimation de Sainte-Musse, merci d'avoir accueilli deux pneumologues avec tant de bienveillance. Merci au Dr Laurent Ducros, pour ton sens clinique, ton humanité et ta philosophie, j'ai énormément appris à tes côtés.

Merci à l'équipe d'oncologie prédictive du CRCM, merci à Nadine, Séverine et José pour votre accueil. Merci Emilie pour ton encadrement et ta gentillesse. Merci à Roxane, Claire, Domitille et Thomas d'avoir partagé cette année avec moi.

A toute l'équipe du service Hérault et du comité de Pathologie thoracique de l'IGR, merci de m'avoir si bien accueillie, c'était un plaisir d'apprendre auprès de vous tous. Sarah, merci de nous avoir materné comme ça. Merci à Benjamin et à mes co-internes pour avoir rendu ce semestre si agréable, vous allez me manquer.

Aux patients et à leurs familles, pour toutes ces leçons de vie A Clémence et Mélanie, pour m'avoir donné les plus belles 
Table des matières

Article original .....................................................................

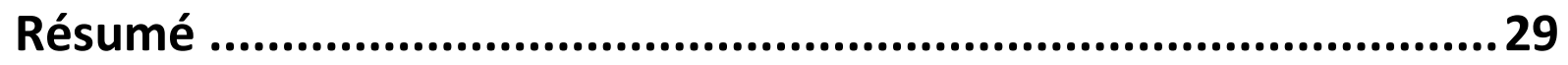

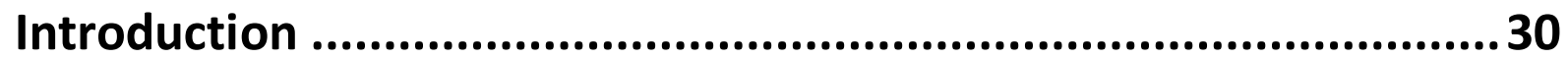

Matériel et Méthodes..................................................................33

Essai SAFIR-02 Lung ....................................................... 33

Population de l'étude ............................................................ 34

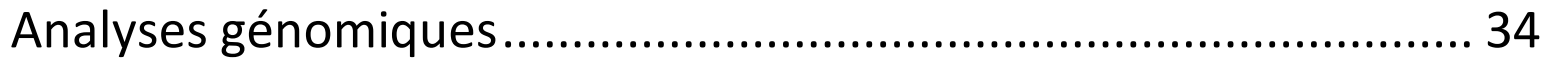

Analyses bio-informatiques................................................ 35

Analyses statistiques ............................................................. 36

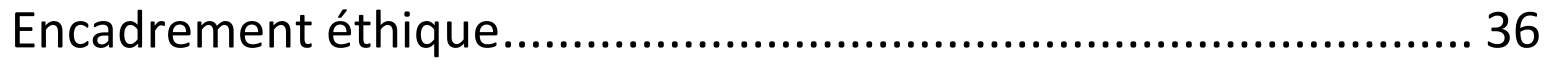

Résultats ...................................................................... 38

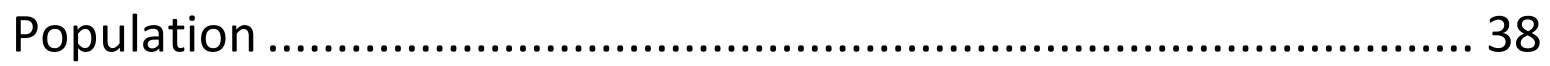

Analyses initiales de CGH-array ............................................ 40

Analyse des interactions protéiques .................................... 42

Analyses initiales de NGS .................................................. 43

Évolution cérébrale pendant la phase de maintenance ............... 44

Discussion............................................................................... 47

Bibliographie ................................................................. 52

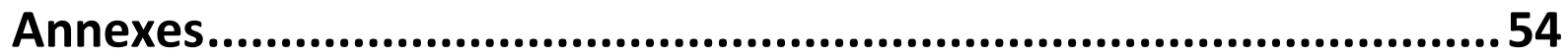




\section{Molecular profiling of non-small cell lung cancer patients with or without brain metastases included in the randomized SAFIR-02 Lung trial and association with intracranial outcome}

Alice MOGENET ${ }^{1}$, MD, Fabrice BARLESI ${ }^{2,3}, \mathrm{MD}$, PhD, Benjamin BESSE${ }^{2}, \mathrm{MD}$, PhD, Stefan MICHIELS ${ }^{4}, 5, \mathrm{PhD}$, Maryam KARIMI ${ }^{4}$,, PhD, Alicia TRAN-DIEN ${ }^{6}$, PhD, Nicolas GIRARD 7 , MD, PhD, Julien MAZIERES ${ }^{8}, \mathrm{MD}, \mathrm{PhD}$, Clarisse AUDIGIER-VALETTE 9 , MD, Pierre-Jean SOUQUET ${ }^{10}$, MD, PhD, Maud KAMAL ${ }^{11}$, PhD, Pierre GESTRAUD ${ }^{12}$, PhD, Abderaouf HAMZA ${ }^{13}$, PharmD, Alexandra JACQUET ${ }^{14}, \mathrm{PhD}$, Marta JIMENEZ ${ }^{14}, \mathrm{PhD}$, Sabrina YARA ${ }^{14}$, PhD, Laurent GREILLIER ${ }^{1}, \mathrm{MD}$, PhD, François BERTUCCl ${ }^{3}, 15, \mathrm{MD}, \mathrm{PhD}$, David PLANCHARD ${ }^{2}$, MD, PhD, Jean-Charles SORIA², MD, PhD, Ivan BIECHE ${ }^{13}$, PharmD, PhD, Pascale TOMASINI ${ }^{1}, \mathrm{MD}$, PhD

${ }^{1}$ Aix Marseille Univ, APHM, INSERM, CNRS, CRCM, Hôpital Nord, Multidisciplinary Oncology and Therapeutic Innovations Department - Marseille. France

${ }^{2}$ Université Paris-Saclay and Medical Oncology, Gustave Roussy - Cancer Campus - 94805 Villejuif. France

${ }^{3}$ Aix Marseille Univ, Centre de Recherche en Cancérologie de Marseille (CRCM), INSERM UMR1068, CNRS UMR725, Laboratoire d'Oncologie Prédictive - Marseille. France

${ }^{4}$ Office of Biostatistics and Epidemiology, Institut Gustave Roussy, Université Paris-Saclay - 94805 Villejuif. France

${ }^{5}$ Oncostat U1018, INSERM, Université Paris-Saclay, labeled Ligue Contre le Cancer - 94805 Villejuif. France

${ }^{6}$ Institut Gustave Roussy, INSERM Unité 981 - 94805 Villejuif. France

${ }^{7}$ Department of Medical Oncology, Institut Curie and Paris-Saclay University - Paris. France

${ }^{8}$ Thoracic Oncology Department, CHU Toulouse - Hôpital Larrey, Toulouse. France

${ }^{9}$ Medical Oncology, Hospital Sainte Musse - Toulon. France

${ }^{10}$ Thoracic Oncology Department, Centre Hospitalier Lyon Sud - Pierre-Bénite. France

${ }^{11}$ Department of Drug Development and Innovation, Institut Curie, PSL Research University - 75005 Paris \& 92210 Saint-Cloud. France

12 Bioinformatics and Computational Systems Biology of Cancer, PSL Research University, Mines Paris Tech, INSERM U900 - 75005 Paris. France

${ }^{13}$ Department of Genetics, Institut Curie, University of Paris -75005 Paris. France

14 UNICANCER - 75654 Paris. France

${ }^{15}$ Department of Medical Oncology. Institut Paoli-Calmettes. Marseille. France.

\section{Corresponding author: Dr Pascale TOMASINI}

Service d'Oncologie Multidisciplinaire et Innovations Thérapeutiques

Hôpital Nord - Chemin des Bourrely - 13915 MARSEILLE CEDEX - France

Email: pascale.tomasini@ap-hm.fr

Tel: +33491965901Fax: +33491965902

Key words: Lung cancer - Brain Metastases - Molecular biology - Targeted therapy -Immunotherapy 


\section{Abstract}

Lung cancer remains the first provider of brain metastases (BM), responsible for a high morbidity and mortality despite recent progresses in local and systemic treatments. Moreover, intracranial response to systemic treatments is inconstant due to several mechanisms. First, whereas molecular and phylogenic BM specificities are still widely unknown, a significant genomic heterogeneity is observed in BM compared to the primary tumor, suggesting the existence of a common precursor then acquiring additional molecular alterations. In addition, pharmacokinetic and pharmacodynamic impact of the blood tumor barrier and brain specific microenvironment are also responsible for inconstant intracranial response. We conducted a study using data from the phase II randomized SAFIR-02 Lung trial. The first objective was to compare the molecular profiles of non-small cell lung cancer (NSCLC) with or without BM. The secondary objective was to explore central nervous system (CNS) outcome on various maintenance treatment regimen according to baseline BM status.

A total of 365 screened patients in the SAFIR-02 Lung trial harboring interpretable molecular data were included in this analysis. Clinical and biological data were collected. Genomic analyses were based on array-comparative genomic hybridization and nextgeneration sequencing following the trial recommendations. Statistical analysis was conducted using $\mathrm{R}$ version 3.5.1. Baseline genomic analyses of copy number variations identified a 12-genes signature (enhanced by 12 adjacent genes) specific of lung cancer BM occurrence, all previously described as part of the oncogenic process (TNS1, PAK2, COBL, CDK5, GLRX3, WNT5B, SETD1B, EGLN3, TOX3, RYR1, PVR, and BCL2L1).

NGS analysis identified a higher proportion of KRAS mutations in the BM-positive group (44.3\% versus $32.3 \%$ ), especially the $\mathrm{G} 12 \mathrm{C}$ mutations (63\% versus $47 \%$ ). In addition, protein interaction analyses highlighted several functional interactions focused on EGFR. Furthermore, the risk of CNS progression was decreased with pemetrexed standard maintenance therapy. The highest rate of CNS progression was observed with durvalumab, probably because of the specific intracranial immune microenvironment.

This work identified a 24-genes signature specific of lung cancer with BM. Further studies are needed to precise the functional implication of these genes and to better understand the brain metastatic process in order to identify new therapeutic targets for the treatment of lung cancer with BM. 


\section{Introduction}

Metastatic non-small cell lung cancer (NSCLC) remains the first cause of cancer-related death worldwide $(1,2)$, particularly because of the high incidence of brain metastases (BM) (3). Lung cancer is indeed the largest provider of $\mathrm{BM}$, with almost $50 \%$ coming from lung cancer, occurring in about $10 \%$ of NSCLC patients at the initial diagnosis and in about $50 \%$ of patients during the entire course of disease (4). Despite significant improvements in local and systemic treatments during the past decade, NSCLC BM are still responsible for high morbidity and mortality with median overall survival (OS) not exceeding 12 months (5). Moreover, local treatments toxicity affects the quality of life and also has to be considered (6). Thus, there is a need to enhance knowledge of BM biology in order to improve NSCLC patients' outcome.

Even if the cellular mechanisms underlying metastatic dissemination are well known, genomic and phylogenetic specificities of brain invasion remain widely unknown. Molecular dismembering of lung cancer revealed the association of some alterations with high (EGFR, $A L K)(7)$ or low (KRAS) (8) incidence of $\mathrm{BM}$, thus involving molecular features in the central nervous system (CNS) metastatic process. Although rare, published molecular BM data highlighted a significant genomic heterogeneity in BM compared to the primary tumor (9) or other metastatic sites. For example, Jiang et al. recently reported significantly higher genomic heterogeneity between primary tumor and BM (median $6.8 \%$ of shared mutations) than between primary tumor and liver metastases (median $66.3 \%$ of shared mutations; $p=0.005$ ) (10). Moreover, phylogenetic reconstructions based on these data suggested that BM process is occurring earlier than other distant lesions. These particular BM genomic features were confirmed and deepened in a study recently published by our team, which successfully identified recurrent mutations in 13 genes (AFF2, ANO3, CCDC178, CRISP3, DRD5, FAM134A, LOR, NCOR2, NELFB, RUNX1T1, SPATA31C1, and TENM3), never identified in primary tumor samples (11). Even if the blood brain barrier (BBB) is certainly involved in this molecular divergence (12), taken together, these data are an argument to assume the existence of a common precursor for lung primary tumor, BM and other distant lesions, then evolving on their own account. During this evolution, the number of mutations and chromosomic alterations acquired is higher in BM than in primary tumors or other metastases (10). 
However, interactions between BM molecular specificities and systemic drug efficiency were poorly explored so far.

Moreover, the central nervous system (CNS) outcome with systemic treatments is still widely unpredictable because patients harboring symptomatic BM are most often excluded from clinical trials, and because of the BBB impact on pharmacokinetic and pharmacodynamic features (13). Therefore, morbidity and mortality due to BM is enhanced by the frequent discrepancies between intracranial and extracranial response to systemic treatments. In NSCLC, the adjunction of an antiangiogenic drug (anti-VEGF monoclonal antibody, bevacizumab) to a standard platinum-based chemotherapy was the first regimen to suggest an improvement of BM outcome (5). Then, despite a higher incidence of BM among EGFRmutant or $A L K$-rearranged NSCLC, impressive CNS efficacy of new generations of tyrosine kinase inhibitors, especially osimertinib and alectinib, succeeded to turn BM patients into long-responders $(14,15)$. To finish, the CNS outcome under immune checkpoint inhibitors (ICI) is widely variable, mainly because of the frequent use of systemic corticosteroids (16), but also because of the CNS immune specificities, such as the lack of cytotoxic T-lymphocytes or the functional implications of astrocytes (17).

Considering these specificities, a better knowledge of lung cancer BM biology will be crucial to proceed with the improvement of lung cancer outcomes. Giving the technical limits to perform molecular analysis on BM samples in daily care, the identification of a BM specificgenomic signature among primary lung tumors or distant metastases will help to improve the management of these patients. Moreover, knowledge improvement of CNS outcome under various NSCLC treatment regimen (chemotherapy, targeted therapy, ICI) will be crucial for BM management. This study was based on the randomized SAFIR-02 Lung trial (18) (Essai intergroupe Unicancer 0105-1305/IFCT1301 SAFIR02 Lung - NCT02117167) data, including exhaustive clinical and molecular data about metastatic lung cancer patients, but also clinical outcome under various systemic first-line maintenance treatment regimen (chemotherapy, $\mathrm{ICl}$, targeted therapies). The first objective of this translational study was to compare the DNA mutational and copy number profiles of NSCLC with or without BM in order to establish a molecular signature associated with BM. The secondary objective was to evaluate CNS outcome on various maintenance treatment regimen according to baseline BM status. 


\section{Patients and Methods}

\section{SAFIR-02 Lung trial}

The French multicentric randomized phase II SAFIR-02 Lung trial enrolled 999 treatmentnaïve advanced NSCLC patients. Other main inclusion criteria were the absence of EGFR or $A L K$ activating alterations, the availability of tissue sample from primary tumor or metastasis (excluding bone) suitable for molecular analysis, and the eligibility for a first-line platinumbased regimen. Patients had to undergo objective response or stability after platinum-based regimen according to RECIST 1.1. Exclusion criteria could be summarized as all the potential contraindications to one of the study drugs (Supplementary Table 1 reports the details of eligibility criteria). Regarding CNS status, only symptomatic or progressive untreated BM after the induction chemotherapy were considered as exclusion criteria. According to the study form, baseline brain MRI or CT-scan was required for every patient at inclusion. During followup, iterative brain imaging (CT-scan or MRI) was required for baseline BM-positive patients or in case of neurological symptoms.

This open-label trial used high-throughput genome analysis as a therapeutic decision tool to compare experimental ( $\operatorname{arm} A$ ) versus standard ( $\operatorname{arm~B)~maintenance~treatments:~a~targeted~}$ treatment (Supplementary Table 2) versus a standard treatment if a targetable alteration was identified (substudy 1 - 175 randomized patients) or durvalumab (anti-PDL1) immunotherapy versus standard treatment in the absence of targetable molecular alteration or contraindication to targeted therapies (substudy $2-183$ randomized patients). The standard maintenance therapy arm was based on pemetrexed for non-squamous NSCLC or erlotinib for squamous NSCLC. The substudy 1 eligibility was defined by the presence of a targetable molecular alteration according to the molecular tumor board (MTB), and molecular alterations were sorted in four categories (Supplementary Table 2). Otherwise, patients were eligible for randomization in substudy 2 . The randomization was based on a 2:1 ratio in favor of the experimental arm in each substudy.

\section{Study population}

Patients were selected from the SAFIR-02 Lung trial and our study therefore followed the trial inclusion and exclusion criteria (Supplementary Table 1). For our first objective, every 
screened patient was eligible; and every randomized patient was eligible for our secondary objectives, with the condition of qualitative molecular data availability.

BM status at baseline was collected according to the trial case report form, and CNS outcome was assessed by investigator review based on scheduled tumor assessment brain CT scan or MRI (systematic in case of baseline BM or neurological symptoms) and defined as the appearance of a new brain lesion, regardless of baseline BM status.

\section{Genomic analysis}

Archival biopsy or new biopsy before cycle three of the induction chemotherapy was required for screening and sent to one of the five genomic platforms involved (Gustave Roussy, Centre Leon Bérard, Institut Bergonié, Institut de Cancérologie de l'Ouest) for DNA extraction, quality control, and genomic analysis. Array-comparative genomic hybridization (array-CGH) and next-generation sequencing (NGS) were performed. Frozen tissue was the preferred sample type. Molecular analysis was performed if tumor cellularity was $>30 \%$ for frozen samples and $>10 \%$ for FFPE samples. For FFPE tissue sections ( 6 sections of $6 \mu \mathrm{m}$ each), tumor-rich areas were macro-dissected, and the samples underwent proteinase $\mathrm{K}$ digestion before DNA extraction with the Maxwell RSC DNA FFPE kit (Promega) kit or the QIAmp DNA FFPE tissue (Qiagen). DNA extraction from frozen biopsies was performed using the AllPrep DNA/RNA Mini Kit (Qiagen) according to the manufacturer's protocol. DNA was quantified using a Qubit 2.0 fluorometer (Thermo Fisher Scientific). In the absence of tissue DNA, a circulating tumor DNA was used for molecular analysis, extracted using the QIAamp Circulating Nucleic Acid (Qiagen).

The NGS panel included 65 critical oncogenes or tumor suppressor genes. The initial PCR step was performed using a $10 \mathrm{ng}$ DNA sample, amplicons were then partially digested to get rid of primer sequences before ligation with adapters and barcodes, amplification and purification. After quality and quantity assessment and equimolar pooling of libraries, sequencing was performed using the lonTorrentS5 or Illumina Miseq technologies. Array-CGH analysis was performed on Affymetrix platform with the CytoScan HD array Kit for DNA extracted from frozen samples and the OncoScan FFPE Assay Kit for DNA extracted from FFPE tissues. Both technologies used single-nucleotide polymorphism probes to provide DNA copy number variations. Genomic data were systematically analyzed by the study MTB to confirm the pathogenicity of identified variants and thus patient's eligibility for substudy 1. 


\section{Bioinformatic analysis}

For NGS analysis, all variants passing the following thresholds were validated: depth of coverage higher than $100 \mathrm{X}$, allelic ratio above $5 \%$ and population frequency lower than $0.1 \%$ in either 1000g, ESP and gnomAD. All somatic mutations were annotated, sorted and interpreted by an expert molecular biologist according to available databases (Cosmic, TumorPortal, TCGA, Cancer Hotspots...). Pathogenic variants were defined as follows: (i) for oncogenes, only mutations driving to gain of function were considered (i.e. hotspots missense mutations, in-frame insertions/deletions/splicing described as oncogenic in the literature), (ii) for tumor suppressor genes (TSG), only mutations driving to loss of function were considered (i.e. truncating alterations (nonsense mutations, frameshift insertions/deletions/splicing) or missense mutations described as deleterious in the literature).

Regarding array-CGH analysis, copy number variations from CytoScan and OncoScan were defined using the $\mathrm{R}$ package $\mathrm{rCGH}$ (v1.16.0 under $\mathrm{R}$ v3.6.3). $\log _{2}$ relative ratios were calculated before centralization of the profile to set the baseline from which copy number alterations were estimated (two copies being the neutral level). Break points in the $\log _{2}$ relative ratio continuity were identified by profile segmentation. These segments were used to detect focal gene amplifications ( $\log 2$ ratio $>1.58$, i.e. fold change $>6$ DNA copies; and amplicon size $<10$ $\mathrm{Mb}$ ) or homozygous deletions ( $\log 2$ ratio $<-1$ ) and was discussed during the tumor board. Focal amplifications and homozygous deletions were compared among the predefined groups and $p$-value $<0.05$ before adjustment was considered as statistically significant. Oncogenic driver research among regions of interest relied on two different approaches. First, the candidate strategy presumed the oncogenic driver to have been previously described as a somatic alteration in lung cancer (among a 23 genes selection) (19). Then, every potential driver was assessed with the discovery strategy, which consisted in a screen among oncoKB and Pubmed databases. Array-CGH analysis were focused on focal amplification and homozygous deletions because of their theragnostic impact compared with copy number variations analysis.

\section{Statistical analysis}

Data were summarized by frequency and percentage for categorical variables and by median and range for continuous variables. Comparisons between groups were performed using the Wilcoxon rank sum test for continuous variables and Chi-square or Fisher exact test for categorical variables. All statistical tests were two sided, and differences were considered 
statistically significant when $p<0.05$. R version 3.6.3 was used for the statistical analyses. False discovery rate (FDR), used for correcting $p$-values for multiple hypothesis testing, was computed using the Benjamini-Hochberg procedure for NGS analyses.

\section{Ethical framework}

The SAFIR-02 Lung trial was approved by the French ethics committee CPP Ile de France 2 on 09 November 2013 (2013-08-04) and the French health authorities ANSM on 17 October 2013 (130975A-12). SAFIR-02 Lung study was conducted in accordance with the Declaration of Helsinki, current International Conference on Harmonisation of Technical Requirements for Registration of Pharmaceuticals for Human Use guidelines and all applicable regulatory and ethical requirements. Patients signed informed consent for biopsy, randomization and use of their biological samples for research purposes. Concerning our study, all patients signed informed consent for the SAFIR-02 Lung trial and ancillary studies and a license contract was established to frame the SAFIR-02 Lung trial data utilization by the investigators (RCAPHM14 0097). 


\section{Results}

\section{Population}

Patients were included between April 2014 and December 2018 among 37 centers in France. Among the 999 included patients, CNS status at baseline was available for 785 patients and 365 had sufficient genomic data quality to be included. Array-CGH data were collected for all the 365 patients, and NGS data for 360 of them ( 5 being excluded because of insufficient tumor tissue sample quality). The population was first divided into two groups according to the baseline BM status, with 107 patients harboring BM, including 67 patients with multiple brain lesions ( 2 or more). Among the 107 BM-positive patients, 47 (44\%) benefited from initial local brain radiation therapy. Patient characteristics highlighted the enrichment of BMpositive group by active smokers $(58.9 \%$ versus $44.2 \% p<0.05)$ and are summarized in Table 1. 


\begin{tabular}{|c|c|c|c|}
\hline Characteristic & $\begin{array}{c}\text { BM-positive } \\
\text { group } \\
(\mathrm{N}=107)\end{array}$ & $\begin{array}{c}\text { BM-negative } \\
\text { group } \\
(\mathrm{N}=\mathbf{2 5 8})\end{array}$ & p-value \\
\hline Age (range) & $64.1(33.0-80.9)$ & $58.9(32.7-83.8)$ & $p=0.116$ \\
\hline \multicolumn{4}{|l|}{ Sex } \\
\hline Male & $60(56.1 \%)$ & $167(64.7 \%)$ & \multirow[t]{2}{*}{$p=0.152$} \\
\hline Female & $47(43.9 \%)$ & $91(35.3 \%)$ & \\
\hline \multicolumn{4}{|l|}{ Smoker status } \\
\hline Active smoker & $63(58.9 \%)$ & $114(44.2 \%)$ & \multirow{4}{*}{$p<0.05$} \\
\hline Former smoker & $31(29.0 \%)$ & $119(46.1 \%)$ & \\
\hline Never smoker & $11(10.2 \%)$ & $23(8.9 \%)$ & \\
\hline Missing & $2(1.9 \%)$ & $2(0.8 \%)$ & \\
\hline \multicolumn{4}{|l|}{ Histology } \\
\hline \multicolumn{4}{|l|}{ carcinoma } \\
\hline Squamous cell carcinoma & $0(0 \%)$ & $0(0 \%)$ & \\
\hline \multicolumn{4}{|l|}{ Initial stage } \\
\hline 1 & $2(1.9 \%)$ & $2(0.8 \%)$ & \multirow{4}{*}{$p=0.053$} \\
\hline II & $0(0 \%)$ & $1(0.4 \%)$ & \\
\hline III & $0(0 \%)$ & $15(5.8 \%)$ & \\
\hline IV & $105(98.1 \%)$ & $240(93.0 \%)$ & \\
\hline $\begin{array}{l}\text { Median number of } \\
\text { metastatic sites }\end{array}$ & $4(1-9)$ & $3(1-9)$ & $p<0.05$ \\
\hline Randomized proportion & 47 (43.9\%) & $106(41.1 \%)$ & \multirow{3}{*}{$p=1.00$} \\
\hline Substudy 1 & $32(68.1 \%)$ & 73 (68.9\%) & \\
\hline Substudy 2 & 15 (31.9\%) & $33(31.1 \%)$ & \\
\hline \multicolumn{4}{|l|}{ First-line treatment } \\
\hline Platin/Pemetrexed & 95 (88.8\%) & $223(86.5 \%)$ & \multirow{5}{*}{$p=0.060$} \\
\hline Platin/Paclitaxel & $4(3.7 \%)$ & $23(8.9 \%)$ & \\
\hline Platin/Vinorelbine & $1(0.9 \%)$ & $0(0 \%)$ & \\
\hline Platin/Gemcitabine & $0(0 \%)$ & $4(1.5 \%)$ & \\
\hline Other & $7(6.6 \%)$ & $8(3.1 \%)$ & \\
\hline
\end{tabular}

Table 1: Baseline patients and tumor characteristics according to the BM status 


\section{Baseline array-CGH analysis}

The most frequent focal amplifications were in 5p15.33 (TERT), 8q24.21 (MYC) and 14q13.3 (NKX2-1) in both BM-positive and negative groups. The candidate strategy failed to identify focal amplifications significantly associated with BM status. With the discovery strategy, significant focal amplifications variation was identified among 12 genes (and 12 adjacent regions) comparing the BM-positive and negative populations (Table 2 - Figure 1 ). Except for EGLN3 (and adjacent NFKBIA), focal amplification was always favoring the BMpositive group. Focal amplification in BCL2L1 gene is illustrated in Figure 1b. These 12 genes have already been described as part of the oncogenic process. However, neither candidate nor discovery strategy succeeded to identify a significant homozygous deletion variation between the BM positive and negative population.

\begin{tabular}{ccccccc}
\hline \multirow{2}{*}{ Chr $^{\dagger}$} & Band & \multicolumn{2}{c}{ FA $^{++}$samples (\%) } & Gene & Adjacent gene(s) & p-value \\
\cline { 3 - 5 } & \multicolumn{2}{c}{$\begin{array}{c}\text { BM-positive } \\
\text { group }\end{array}$} & $\begin{array}{c}\text { BM-negative } \\
\text { group }\end{array}$ & & & \\
\hline 2 & $\mathrm{q} 35$ & $3(2.80 \%)$ & $0(0 \%)$ & TNS1 & & 0.039 \\
3 & $\mathrm{q} 29$ & $4(3.73 \%)$ & $0(0 \%)$ & PAK2 & TFRC & 0.010 \\
7 & $\mathrm{p} 12.1$ & $9(8.41 \%)$ & $7(2.71 \%)$ & COBL & EGFR & 0.032 \\
7 & $\mathrm{q} 36.1$ & $8(7.48 \%)$ & $6(2.32 \%)$ & CDK5 & AGAP3 & 0.042 \\
10 & $\mathrm{q} 26.3$ & $6(5.61 \%)$ & $2(0.77 \%)$ & GLRX3 & MKI67 & 0.013 \\
12 & $\mathrm{p} 13.33$ & $6(5.61 \%)$ & $2(0.77 \%)$ & WNT5B & RAD52 & 0.013 \\
12 & $\mathrm{q} 24.31$ & $3(2.80 \%)$ & $0(0 \%)$ & SETD1B & & 0.039 \\
14 & $\mathrm{q} 13.1$ & $0(0 \%)$ & $14(5.43 \%)$ & EGLN3 & NFKBIA & 0.031 \\
16 & $\mathrm{q} 12.1$ & $4(3.74 \%)$ & $1(0.39 \%)$ & TOX3 & & 0.044 \\
19 & $\mathrm{q} 13.2$ & $8(7.48 \%)$ & $4(1.55 \%)$ & RYR1 & MAP4K1/ACTN4 & 0.010 \\
19 & $\mathrm{q} 13.31$ & $6(5.61 \%)$ & $3(1.16 \%)$ & PVR & CEACAM19/BCL3 & 0.034 \\
20 & $\mathrm{q} 11.21$ & $6(5.61 \%)$ & $3(1.16 \%)$ & BCL2L1 & TPX2/FGR1B & 0.034 \\
\hline
\end{tabular}

Table 2: Focal amplifications significantly associated with BM status

\footnotetext{
t: Chromosome

t+: Focal amplification
} 
9,00\% $\square$ Focal amplification in the BM positive group $\square$ Focal amplification in the BM negative group

$8,00 \%$

$7,00 \%$

$6,00 \%$

$5,00 \%$

$4,00 \%$

$3,00 \%$

$2,00 \%$

$1,00 \%$

$0,00 \%$

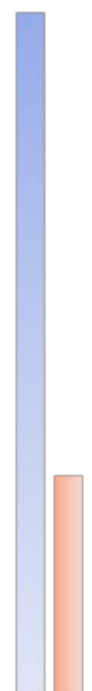

a

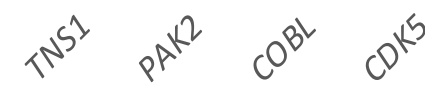
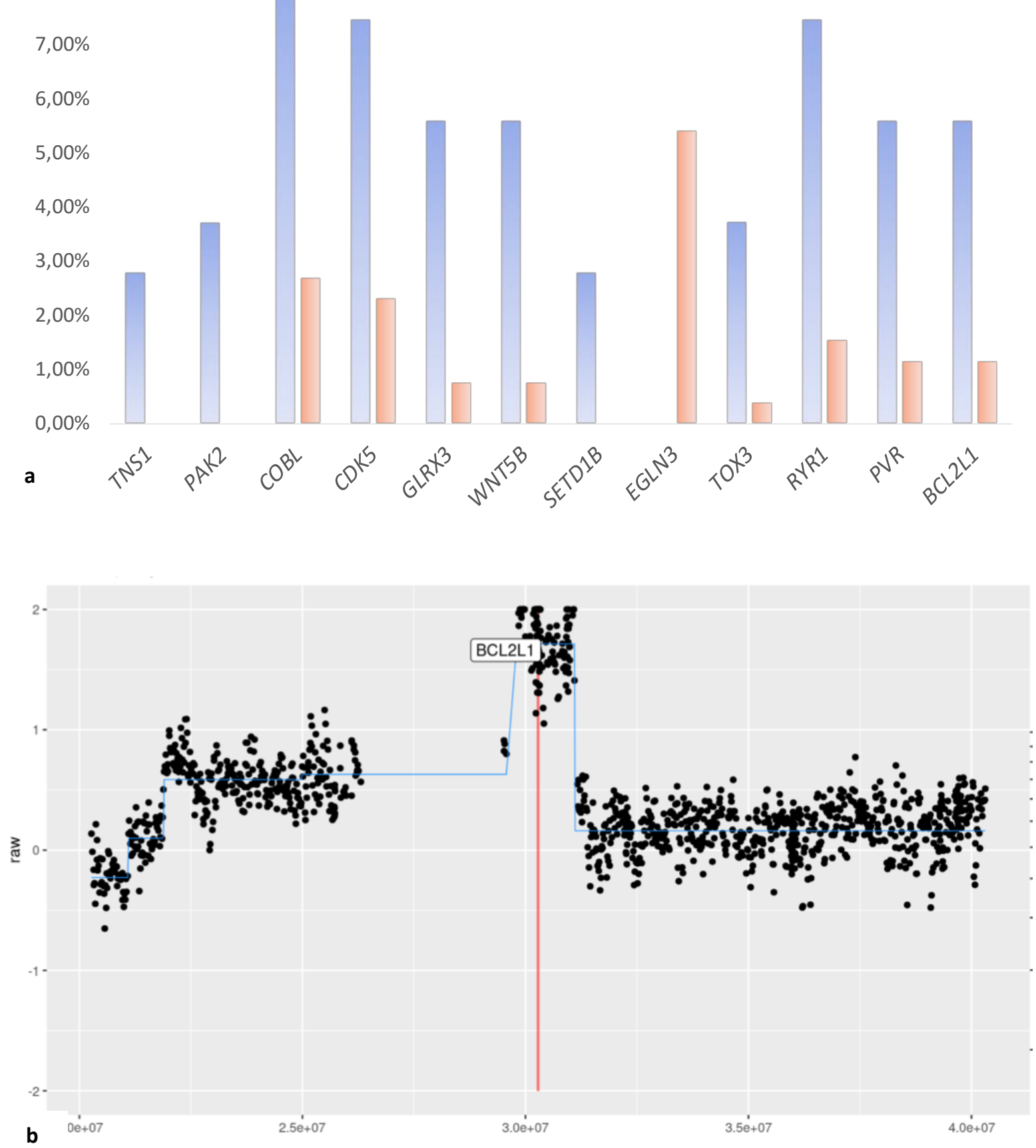

\section{Figure 1:}

a: Schematic representation of significant focal amplifications variations between the BMpositive and BM-negative groups

b: Illustration of a focal amplification in the BCL2L1 gene 


\section{Protein interactions analyses}

To go further, we performed protein interaction analyses using STRING (Search Tool for the Retrieval of Interacting Genes/Proteins) molecular database in order to explore the functional implications of our findings. Among the 12 identified genes, only BCL2L1 and TNS1 proteins were found to directly interact (co-expression, experimental data and literature data). If the 12 adjacent gene products were added to the process, several interactions were identified (Figure 2a), focusing on EGFR. To finish, protein interactions were assessed between the 12 genes identified in our study and the 13 genes signature previously published by our team (11). As shown in Figure $2 b$, protein interaction was observed with RUNX1T1, NCOR2 and LOR.

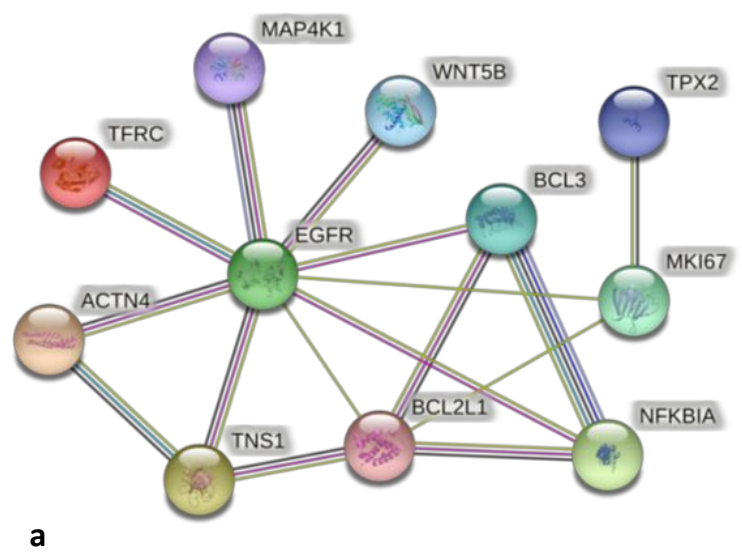

a

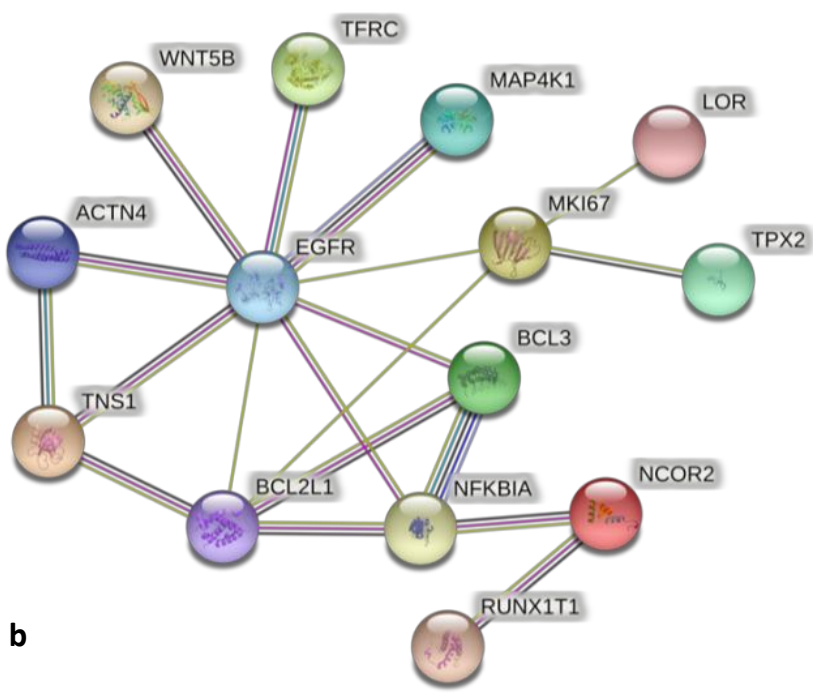

Figure 2: Protein-Protein interaction networks between the products of the 24 genes identified in the present study (a) and the 13 genes identified in our pilot study (b). Interactions as represented as follow:

Green line $=$ literature co-occurrence

Black line $=$ co-expression

Pink line $=$ experimental interaction

Blue line = public database association 


\section{Baseline NGS analysis}

In both BM-positive and BM-negative groups, a median of two molecular variants was identified in each sample (mean 2.16 and 2.25, respectively). According to the predefined criteria (depth of coverage higher than 100X, allelic ratio above $5 \%$ and population frequency lower than $0.1 \%$ in either 1000g, ESP and gnomAD), 23 genes of the panel were selected for the analysis (ATM, BRAF, BRCA1, BRCA2, CTNNB1, EGFR, ERBB2, ERBB3, FBXW7, KEAP1, KRAS, MAP2K1, MAP2K4, MAP3K1, MET, NF1, NFE2L2, NRAS, PIK3CA, PIK3R1, STK11, TP53 and VHL). KRAS and TP53 were the most frequent altered genes in both the BM-positive $(44.3 \%$ and $43.4 \%$, respectively) and BM-negative groups ( $32.3 \%$ and $40.2 \%$, respectively). Comparing the BM-positive and BM-negative populations, only KRAS mutations were found to be significantly associated with the presence of $\operatorname{BM}(p=0.005)$. KRAS mutation was found in 131 of the 360 patients analyzed with NGS (36.4\%), including 47 patients in the BM-positive group (44.3\%) and 84 in the BM-negative group (33.1\%). Repartition of KRAS mutations between both groups is summarized in Figure 3. We observed a higher prevalence of the KRAS G12C mutation in the BM-positive group (63\%). In the BM-negative group, even if KRAS G12C mutation remained dominant (47\%), we observed a higher proportion of KRAS G12V (21\%) and KRAS G12A (12\%) mutations.

KRAS alterations in the BM positive group

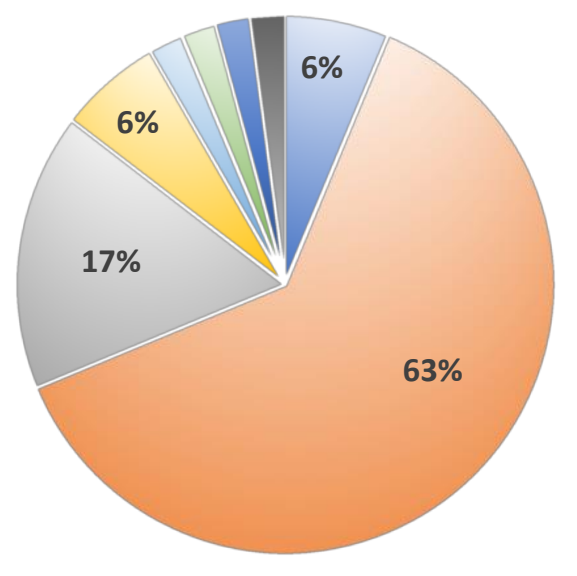

KRAS alterations in the $\mathrm{BM}$ negative group

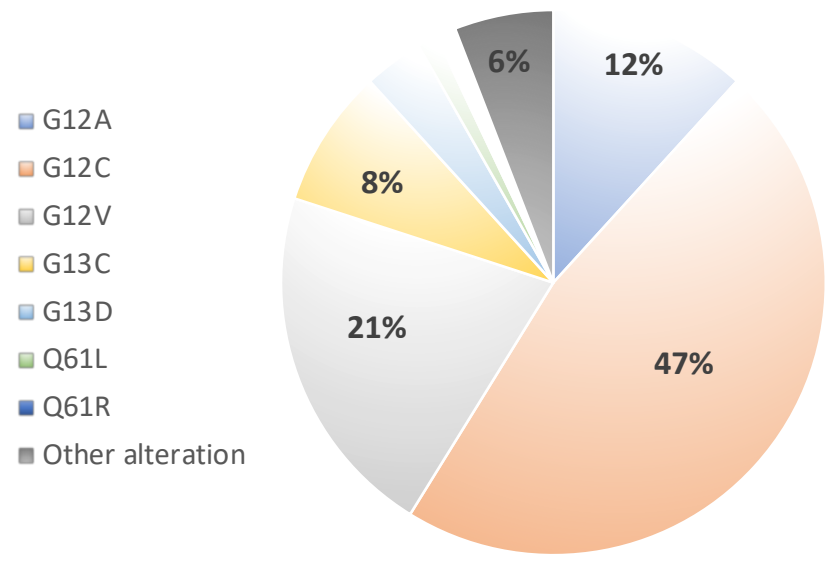

Figure 3: Repartition of KRAS alterations between the groups, depending on BM status 


\section{CNS outcome during the maintenance phase}

Out of the 365 patients included in our study, 153 (41.9\%) were randomized including 47 patients with baseline BM and 106 without baseline BM. Among them, 137 (89.5\%) experienced disease progression before radiologic data cutoff, planned after 18 weeks of maintenance therapy. 40 out of 47 patients (85.1\%) with baseline BM and 97 out of 106 patients (91.5\%) without BM experienced disease progression. Brain evolution data were available for 124 out of the 137 patients who underwent disease progression. Brain progression was observed for 17 patients in the BM-positive group (44.7\%) and 9 patients in the BM negative group (10.5\%). Occurrence of brain progression per the treatment-arm is summarized in the Figure $4 \mathrm{a}$. Among the 89 randomized patients in the experimental arm (arm A of both substudy 1 and 2), 20 patients (22.5\%) experienced brain progression, versus 6 out of 35 randomized patients (17.1\%) in the standard chemotherapy arm (arm B of both substudy 1 and 2). Regardless of the initial BM status, the highest proportion of brain progression was identified in the durvalumab arm (Substudy 2 - Arm A), accounting for 7 CNS progression (28\%) (Figure 4b).

Focusing on KRAS mutations distribution, a G12C mutation was found for 8 patients among the 12 KRAS-mutant NSCLC patients experiencing brain progression, thus representing $66 \%$ of the mutations. On the other way, $\mathrm{G} 12 \mathrm{C}$ mutations accounted for $38 \%$ of $K R A S$ mutations in the non-brain progressive population (G12V 26\% - G13C 24\%), regardless of the initial BM status. 


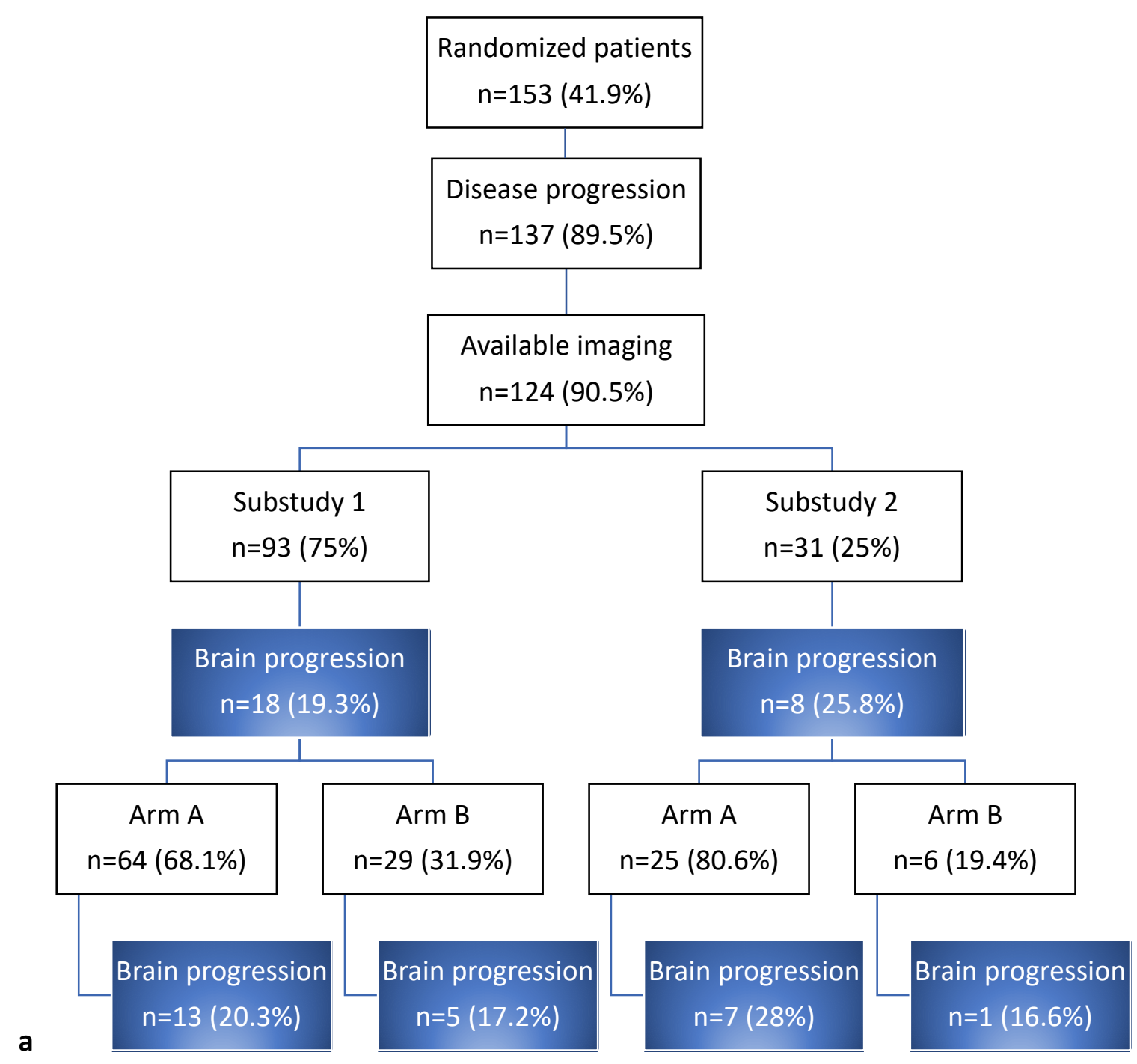

$30 \%$

25

20

15

10
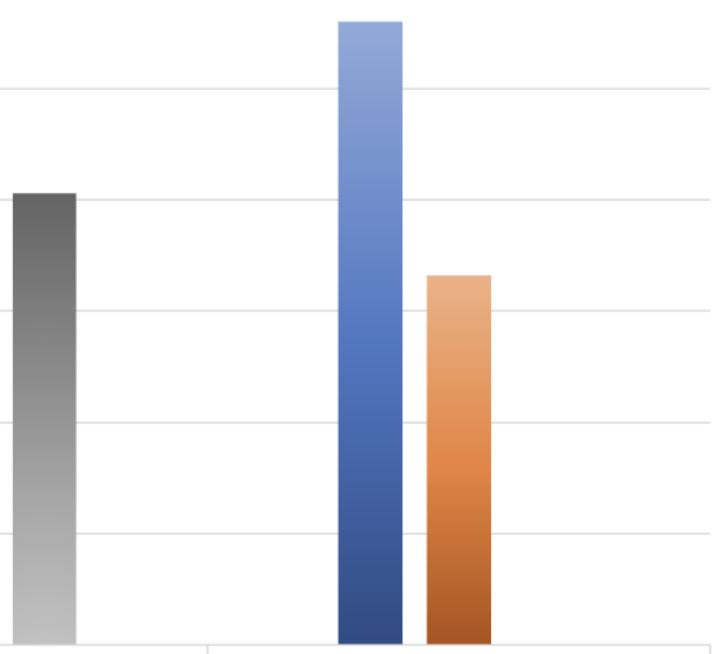

- Durvalumab

Pemetrexed

Targeted therapy

5

b

Substudy 2 


\section{Figure 4:}

a: Flow chart of brain progression according to maintenance treatment type received Substudy 1: Presence of an actionable molecular alteration

ARM A: Experimental treatment with a targeted therapy

ARM B: Standard treatment with pemetrexed

Substudy 2: Absence of an actionable molecular alteration or contraindication to targeted therapy

ARM A: Experimental treatment with durvalumab

ARM B: Standard treatment with pemetrexed

b: Histogram representation of brain progression according to maintenance treatment type received 


\section{Discussion}

Knowing the high frequency, morbidity and mortality related to lung cancer BM, there is a need for a better characterization of BM molecular profile and a better understanding of CNS outcome with systemic treatments. We conducted the largest study to date assessing the molecular specificities of lung cancer patients with BM. Comparative analysis of focal amplifications identified a 12-genes signature, enhanced by 12 adjacent genes, statistically associated with the presence of BM in NSCLC. The discovery strategy requires a functional implication of every selected gene in the oncogenic process, thus strengthening a clear involvement of the signature in the brain dissemination process. Moreover, protein analyses highlighted several interactions between the identified genes but also with three genes of the brain-specific signature previously identified within our pilot study (11). The main strengths of this work are the prospective and randomized design of the phase II SAFIR-02 Lung trial and the great quality and amount of molecular data. Furthermore, samples were extracted from primary lung tumors or various distant metastatic sites, representative of routine samples used for molecular testing.

All 24 genes identified using the discovery strategy and associated with the presence of baseline BM have already been described as part of the oncogenic process, and thus possibly involved in the brain metastatic invasion. Gene implication in several main oncogenic pathways is corroborating the signature biological relevance. For example, TPX2, TNS1 and CEACAM19 are involved in the PI3K/AKT/mTOR pathway and described in various tumor types as associated with aggressive disease (20-22). TFRC, encoding for the transferrin receptor TFR1, is a key regulator of the ferroptosis mechanism (23). TFR1 role was especially described in the brain oncogenesis since early stages and associated with poorer outcome $(24,25)$. MKI67, TNS1, WNT5B and ACTN4 are described in the proliferation process $(26,27)$. RAD52 (homologous recombination), CDK5 and BCL2L1 are involved in the DNA damage repair process, thus impacting cancer outcome and treatment efficacy (28-31). PVR is known as a part of the TIGIT immune checkpoint axis, and PVR overexpression is associated with aggressive breast cancer subtype (32). MAP4K1 is involved in the JNK/c-Jun pathway, regulating cell invasion and migration and associated with cisplatin resistance (33). Moreover, 
some identified genes are also described in neurologic processes. CDK5 is known to be a key regulator of cytoskeletal remodeling, neuronal signaling and brain development, and involved in several neurodegenerative processes (34). AGAP3 is a component of the NMDA receptor complex that regulates Ras/ERK signaling, responsible for synapses strengthening (35). Lastly, EGLN3 which promotes HIF degradation is involved in glioma vascular normalization and invasiveness (36), and BCL3 overexpression is associated with a more malignant phenotype of glioblastoma and a lower response to temozolomide by inducing an epithelio-mesenchymal transition (37).

Biological relevance of our signature is enhanced by protein interaction analyses. Indeed, we observed a major role of EGFR as a brain dissemination driver even if activating mutations were excluded from the study. Analysis of EGFR focal amplification was sufficient to bring out the association between EGFR amplification and the presence of baseline BM. The interaction with several other proteins also related to the presence of BM (WNT5B, MAP4K1, TFRC, ACTN4, TNS1, BCL3 and BCL2L1) strengthens the implication of EGFR in the brain metastatic process. In the neuro-oncology field, EGFR amplification, found in more than $40 \%$ of glioblastomas, was described for many years as an early progression driver $(38,39)$. Protein interactions beside EGFR mostly involved DNA damage repair pathway or cellular proliferation, without clear functional co-occurrence in lung or brain malignancies to date in the literature. We also succeeded to highlight protein interactions between our signature (via KI67 and NFKBIA) and products from genes previously identified as specifically altered in BM tissue (11). Despite the lack of clear involvement of LOR in the oncogenic process, NCOR2 was described as a transcription-repressive regulator in lung adenocarcinoma, thus appearing as a tissue-dependent tumor regulator (40). Unfortunately, there is no available data about NCOR2 function in BM or brain primary tumors. Moreover, RUNX1T1 is described as a part of neuronal differentiation in vitro (41) and as an epigenetic regulator in small cell lung cancer (42), in addition of being involved in the liver metastatic process of pancreatic endocrine malignancies (43).

Comparative NGS analyses identified a higher proportion of patients harboring KRAS mutation in the BM group. This result was unexpected giving the supposed protective role of KRAS mutations on brain dissemination (8). This result may be explained by the higher 
proportion of active smokers in the BM-positive group but also by the repartition of KRAS mutations in our study. Indeed, the fraction of G12C mutations was higher in the BM group (63\% versus $47 \%$ ), and even greater in the group of patients who had CNS progression (73\% versus 38\%). Growing evidence concerning KRAS biology highlighted an association between the $\mathrm{G} 12 \mathrm{C}$ alteration and a lower rate of phosphorylated AKT compared to other KRAS alterations, thus resulting in an offset using the MEK pathway (44). Despite the lack of clear relation between the MEK pathway and the brain dissemination process, this biological specificity could be at least partially responsible for the high incidence of G12C alteration in the BM group. Moreover, KRAS G12C mutation is already known to have a poorer prognosis and a decreased response rate to platinum-based chemotherapy than other KRAS mutations, maybe because of the implication of MEK pathway $(45,46)$.

Furthermore, CNS progression data highlighted, as expected, a higher rate of CNS progression among patients with baseline BM (44.7\% versus 10.5\%). Even if baseline prevalence of BM in our study is consistent with literature data $29.3 \%$ in our study versus $26.8 \%$ in the review published by Cagney $D N$ and al (47)), we observed a lower rate of CNS progression after the first-line treatment. This result can be explained by exclusion of patients harboring symptomatic BM at baseline or progressive at randomization of the SAFIR-02 Lung trial. As a result, the small sample size of brain progressors subgroup did not allow us to perform statistical analyses in order to identify molecular features of CNS progression in each substudy arm. However, we observed a lower rate of brain progression in both substudies 1 and 2 among patients randomized in the pemetrexed arm (standard treatment). The good pemetrexed CNS efficacy has already been described in several clinical trials compared to other chemotherapy regimen $(48,49)$. Despite an impressive brain efficacy of targeted therapies in the frequent molecular alterations, especially $A L K$ and EGFR $(50,51)$, CNS progression was slightly higher in our study in the targeted therapy arm. This can be explained by a lack of systemic efficacy of the study drugs, pharmacokinetics and pharmacodynamics features of the molecule or the brain prognosis associated with the selected alterations. To finish, the highest rate of CNS progression was observed in the durvalumab arm. Data regarding CNS efficacy of $\mathrm{ICl}$ are rare in the literature, patients harboring BM being excluded of main ICl clinical trials because of the frequent use of corticosteroids. A previously reported work conducted in our team suggested that $\mathrm{ICI}$ brain control was depending on the addition 
of a focal brain treatment (surgery, radiosurgery, stereotaxic irradiation), which was optional for the inclusion in the SAFIR-02 Lung trial (16). CNS control with ICI needs to be further explored, especially in order to find predictive biomarkers of systemic and intracranial response, knowing the high specificity of brain immunity (52). Indeed, microglia ensures local innate immunity and astrocytes represents the essential adaptative CNS effectors.

We identified a few limits to our study. First, patient selection depending on the CNS status may lack of representativity for BM patients encountered by daily care, often symptomatic at the time of diagnosis. We can also discuss the use of a limited NGS panel for molecular analysis. Full exome analysis is now reachable for clinical trials and may have provided precious information. Finally, exploring molecular specificities of BM without paired BM tissue could be considered as a scientific limit. Thus, giving the difficulties to obtain brain tissue, molecular specificities of BM will have to be extrapolated from primary tumor in order to have clinical impact.

To go further, the transposition of this work in a routine unselected population who has benefited from large NGS analysis would be interesting as a validation cohort. Then, functional analysis of this preliminary signature would help us precise the implication of the identified genes in the brain metastatic process. First, we could identify potential therapeutic targets for lung cancer BM, in order to improve prognosis in case of CNS dissemination, but also to prevent BM in adjuvant setting if a CNS susceptibility molecular profile is identified on the primary tumor. Despite biological progress, active tobacco-smoking remains a major risk for developing BM worsening NSCLC prognosis, inking tobacco cessation policies importance to struggle NSCLC.

In conclusion, we conducted the largest study to date assessing molecular features of lung cancer with BM and succeeded to identify a 24-genes signature, whose focal amplification is associated with the presence of baseline BM, and all involved in the oncogenic process. In a near future, the identification of a specific BM signature on primary tumor could help to prevent CNS progression and improve NSCLC outcome. 


\section{Bibliography}

1. Barta JA, Powell CA, Wisnivesky JP. Global Epidemiology of Lung Cancer. Ann Glob Health. 22 janv 2019;85(1).

2. Ferlay J, Colombet M, Soerjomataram I, Mathers C, Parkin DM, Piñeros M, et al. Estimating the global cancer incidence and mortality in 2018: GLOBOCAN sources and methods. Int J Cancer. 15 avr 2019;144(8):1941-53.

3. Sperduto PW, Yang TJ, Beal K, Pan H, Brown PD, Bangdiwala A, et al. Estimating Survival in Patients With Lung Cancer and Brain Metastases: An Update of the Graded Prognostic Assessment for Lung Cancer Using Molecular Markers (Lung-molGPA). JAMA Oncol. 1 juin 2017;3(6):827-31.

4. Sørensen JB, Hansen HH, Hansen M, Dombernowsky P. Brain metastases in adenocarcinoma of the lung: frequency, risk groups, and prognosis. J Clin Oncol Off J Am Soc Clin Oncol. sept 1988;6(9):1474-80.

5. Besse B, Le Moulec S, Mazières J, Senellart H, Barlesi F, Chouaid C, et al. Bevacizumab in Patients with Nonsquamous Non-Small Cell Lung Cancer and Asymptomatic, Untreated Brain Metastases (BRAIN): A Nonrandomized, Phase II Study. Clin Cancer Res Off J Am Assoc Cancer Res. 15 avr 2015;21(8):1896-903.

6. Peters S, Bexelius C, Munk V, Leighl N. The impact of brain metastasis on quality of life, resource utilization and survival in patients with non-small-cell lung cancer. Cancer Treat Rev. avr 2016;45:139-62.

7. Rangachari D, Yamaguchi N, VanderLaan PA, Folch E, Mahadevan A, Floyd SR, et al. Brain metastases in patients with EGFR-mutated or ALK-rearranged non-small-cell lung cancers. Lung Cancer Amst Neth. avr 2015;88(1):108-11.

8. Tomasini P, Serdjebi C, Khobta N, Metellus P, Ouafik L, Nanni I, et al. EGFR and KRAS Mutations Predict the Incidence and Outcome of Brain Metastases in Non-Small Cell Lung Cancer. Int J Mol Sci. 18 déc 2016;17(12).

9. Brastianos PK, Carter SL, Santagata S, Cahill DP, Taylor-Weiner A, Jones RT, et al. Genomic Characterization of Brain Metastases Reveals Branched Evolution and Potential Therapeutic Targets. Cancer Discov. nov 2015;5(11):1164-77.

10. Jiang T, Fang Z, Tang S, Cheng R, Li Y, Ren S, et al. Mutational Landscape and Evolutionary Pattern of Liver and Brain Metastasis in Lung Adenocarcinoma. J Thorac Oncol. févr 2021;16(2):237-49.

11. Tomasini et al. P. Tomasini, S. Gilles, E. Pellegrino, I. Nanni-Metellus, J.-M. Robitaille, F. Barlesi, L. Ouafik, P. Metellus, Comparative genomic analysis of primary tumors and paired Brain Metastases in lung cancer patients: a whole exome sequencing study, Annu. Brain Metastases Res. Emerg. Ther. (2016) 66-67.

12. Wrobel JK, Toborek M. Blood-brain Barrier Remodeling during Brain Metastasis Formation. Mol Med Camb Mass. sept 2016;22:32-40.

13. Patel MM, Patel BM. Crossing the Blood-Brain Barrier: Recent Advances in Drug Delivery to the Brain. CNS Drugs. févr 2017;31(2):109-33.

14. Reungwetwattana T, Nakagawa K, Cho BC, Cobo M, Cho EK, Bertolini A, et al. CNS Response to Osimertinib Versus Standard Epidermal Growth Factor Receptor Tyrosine Kinase Inhibitors in Patients With Untreated EGFR-Mutated Advanced Non-Small-Cell Lung Cancer. J Clin Oncol Off J Am Soc Clin Oncol. 28 août 2018;JCO2018783118.

15. Gadgeel S, Peters S, Mok T, Shaw AT, Kim DW, Ou SI, et al. Alectinib versus crizotinib in treatment-naive anaplastic lymphoma kinase-positive (ALK+) non-small-cell lung cancer: CNS efficacy results from the ALEX study. Ann Oncol Off J Eur Soc Med Oncol. 01 2018;29(11):2214-22.

16. Bermudez J, Mascaux C, Trigui Y, Biemar J, Boucekine M, Greillier L, et al. Predictive Factors of Intracranial Response of Immune Checkpoint Inhibitors in Patients with Brain Metastasis from Non-Small Cell Lung Cancer. J Cancer Ther. 2019;10(08):692-707. 
17. Vilariño N, Bruna J, Bosch-Barrera J, Valiente M, Nadal E. Immunotherapy in NSCLC patients with brain metastases. Understanding brain tumor microenvironment and dissecting outcomes from immune checkpoint blockade in the clinic. Cancer Treat Rev. sept 2020;89:102067.

18. Barlesi F, Karimi M, Tomasini P, Daniel C, Raimbourg J, Quoix A-E, et al. 1273P Durvalumab (D) compared to maintenance chemotherapy (SoC) in patients (pts) with metastatic non-small cell lung cancer (NSCLC): Results from the randomized SAFIR02 LUNG-IMMUNO trial. Ann Oncol. sept 2020;31:S823.

19. Campbell JD, Alexandrov A, Kim J, Wala J, Berger AH, Pedamallu CS, et al. Distinct patterns of somatic genome alterations in lung adenocarcinomas and squamous cell carcinomas. Nat Genet. juin 2016;48(6):607-16.

20. Zhou F, Wang M, Aibaidula M, Zhang Z, Aihemaiti A, Aili R, et al. TPX2 Promotes Metastasis and Serves as a Marker of Poor Prognosis in Non-Small Cell Lung Cancer. Med Sci Monit Int Med J Exp Clin Res. 4 août 2020;26:e925147.

21. Duan J, Wang L, Shang L, Yang S, Wu H, Huang Y, et al. miR-152/TNS1 axis inhibits non-small cell lung cancer progression through Akt/mTOR/RhoA pathway. Biosci Rep. 29 janv 2021;41(1).

22. Hu X, Chen M, Li Y, Wang Y, Wen S, Jun F. Aberrant CEACAM19 expression is associated with metastatic phenotype in penile cancer. Cancer Manag Res. 2019;11:715-25.

23. Shen Y, Li X, Dong D, Zhang B, Xue Y, Shang P. Transferrin receptor 1 in cancer: a new sight for cancer therapy. Am J Cancer Res. 2018;8(6):916-31.

24. Chirasani SR, Markovic DS, Synowitz M, Eichler SA, Wisniewski P, Kaminska B, et al. Transferrin-receptor-mediated iron accumulation controls proliferation and glutamate release in glioma cells. J Mol Med Berl Ger. févr 2009;87(2):153-67.

25. Weston C, Klobusicky J, Weston J, Connor J, Toms SA, Marko NF. Aberrations in the Iron Regulatory Gene Signature Are Associated with Decreased Survival in Diffuse Infiltrating Gliomas. PloS One. 2016;11(11):e0166593.

26. Zhou H, Zhang Y, Wu L, Xie W, Li L, Yuan Y, et al. Elevated transgelin/TNS1 expression is a potential biomarker in human colorectal cancer. Oncotarget. 2 janv 2018;9(1):1107-13.

27. Jiang S, Zhang M, Zhang $\mathrm{Y}$, Zhou W, Zhu T, Ruan $\mathrm{Q}$, et al. WNT5B governs the phenotype of basal-like breast cancer by activating WNT signaling. Cell Commun Signal CCS. 28 août 2019;17(1):109.

28. Nogueira A, Fernandes M, Catarino R, Medeiros R. RAD52 Functions in Homologous Recombination and Its Importance on Genomic Integrity Maintenance and Cancer Therapy. Cancers. 23 oct 2019;11(11).

29. Liu W, Li J, Song Y-S, Li Y, Jia Y-H, Zhao H-D. Cdk5 links with DNA damage response and cancer. Mol Cancer. 14 mars 2017;16(1):60.

30. Zeng J, Xie S, Liu Y, Shen C, Song X, Zhou G-L, et al. CDK5 Functions as a Tumor Promoter in Human Lung Cancer. J Cancer. 2018;9(21):3950-61.

31. Warren CFA, Wong-Brown MW, Bowden NA. BCL-2 family isoforms in apoptosis and cancer. Cell Death Dis. 21 févr 2019;10(3):177.

32. Stamm H, Oliveira-Ferrer L, Grossjohann E-M, Muschhammer J, Thaden V, Brauneck F, et al. Targeting the TIGIT-PVR immune checkpoint axis as novel therapeutic option in breast cancer. Oncoimmunology. 2019;8(12):e1674605.

33. Bai Y, Liu X, Qi X, Liu X, Peng F, Li H, et al. PDIA6 modulates apoptosis and autophagy of nonsmall cell lung cancer cells via the MAP4K1/JNK signaling pathway. EBioMedicine. avr 2019;42:311-25.

34. Shah K, Rossie S. Tale of the Good and the Bad Cdk5: Remodeling of the Actin Cytoskeleton in the Brain. Mol Neurobiol. avr 2018;55(4):3426-38.

35. Oku Y, Huganir RL. AGAP3 and Arf6 regulate trafficking of AMPA receptors and synaptic plasticity. J Neurosci Off J Soc Neurosci. 31 juill 2013;33(31):12586-98.

36. Sciorra VA, Sanchez MA, Kunibe A, Wurmser AE. Suppression of glioma progression by Egln3. PloS One. 2012;7(8):e40053.

37. Wu L, Bernal GM, Cahill KE, Pytel P, Fitzpatrick CA, Mashek $\mathrm{H}$, et al. BCL3 expression 
promotes resistance to alkylating chemotherapy in gliomas. Sci Transl Med. 4 juill 2018;10(448). 38. Brennan CW, Verhaak RGW, McKenna A, Campos B, Noushmehr H, Salama SR, et al. The somatic genomic landscape of glioblastoma. Cell. 10 oct 2013;155(2):462-77.

39. Eskilsson E, Røsland GV, Solecki G, Wang Q, Harter PN, Graziani G, et al. EGFR heterogeneity and implications for therapeutic intervention in glioblastoma. Neuro-Oncol. 18 mai 2018;20(6):743-52.

40. Alam H, Li N, Dhar SS, Wu SJ, Lv J, Chen K, et al. HP1Y Promotes Lung Adenocarcinoma by Downregulating the Transcription-Repressive Regulators NCOR2 and ZBTB7A. Cancer Res. 15 juill 2018;78(14):3834-48.

41. Zou L, Li H, Han X, Qin J, Song G. Runx1t1 promotes the neuronal differentiation in rat hippocampus. Stem Cell Res Ther. 22 avr 2020;11(1):160.

42. He T, Wildey G, McColl K, Savadelis A, Spainhower K, McColl C, et al. Identification of RUNX1T1 as a potential epigenetic modifier in small-cell lung cancer. Mol Oncol. janv 2021;15(1):195-209.

43. Nasir A, Helm J, Turner L, Chen D-T, Strosberg J, Hafez N, et al. RUNX1T1: a novel predictor of liver metastasis in primary pancreatic endocrine neoplasms. Pancreas. mai 2011;40(4):627-33.

44. Friedlaender A, Drilon A, Weiss GJ, Banna GL, Addeo A. KRAS as a druggable target in NSCLC: Rising like a phoenix after decades of development failures. Cancer Treat Rev. avr 2020;85:101978.

45. Ihle NT, Byers LA, Kim ES, Saintigny P, Lee JJ, Blumenschein GR, et al. Effect of KRAS oncogene substitutions on protein behavior: implications for signaling and clinical outcome. J Natl Cancer Inst. 8 févr 2012;104(3):228-39.

46. Ferrer I, Zugazagoitia J, Herbertz S, John W, Paz-Ares L, Schmid-Bindert G. KRAS-Mutant nonsmall cell lung cancer: From biology to therapy. Lung Cancer Amst Neth. oct 2018;124:53-64.

47. Cagney DN, Martin AM, Catalano PJ, Redig AJ, Lin NU, Lee EQ, et al. Incidence and prognosis of patients with brain metastases at diagnosis of systemic malignancy: a population-based study. Neuro-Oncol. 19 oct 2017;19(11):1511-21.

48. Moro-Sibilot D, Smit E, de Castro Carpeño J, Lesniewski-Kmak K, Aerts JG, Villatoro R, et al. Non-small cell lung cancer patients with brain metastases treated with first-line platinum-doublet chemotherapy: Analysis from the European FRAME study. Lung Cancer. déc 2015;90(3):427-32.

49. Yu X, Fan Y. Effect of pemetrexed on brain metastases from nonsmall cell lung cancer with wild-type and unknown EGFR status. Medicine (Baltimore). janv 2019;98(3):e14110.

50. Tomasini P, Egea J, Souquet-Bressand M, Greillier L, Barlesi F. Alectinib in the treatment of ALK-positive metastatic non-small cell lung cancer: clinical trial evidence and experience with a focus on brain metastases. Ther Adv Respir Dis. déc 2019;13:1753466619831906.

51. Soria J-C, Ohe Y, Vansteenkiste J, Reungwetwattana T, Chewaskulyong B, Lee KH, et al. Osimertinib in Untreated EGFR -Mutated Advanced Non-Small-Cell Lung Cancer. N Engl J Med. 11 janv 2018;378(2):113-25.

52. Di Giacomo AM, Valente M, Cerase A, Lofiego MF, Piazzini F, Calabrò L, et al. Immunotherapy of brain metastases: breaking a « dogma ». J Exp Clin Cancer Res CR. 17 oct 2019;38(1):419.

\section{Supplementary Data}




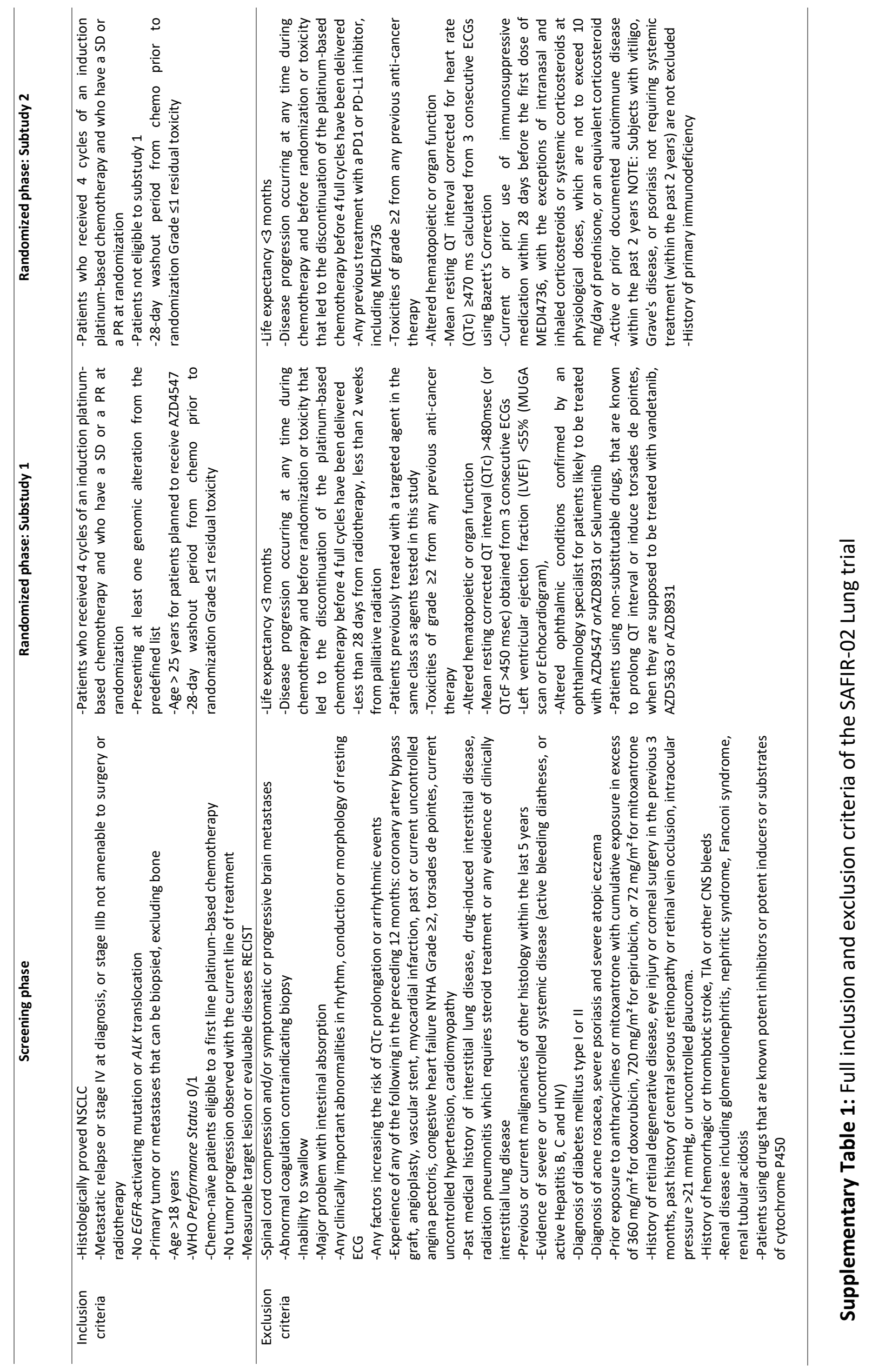




\begin{tabular}{|c|c|c|}
\hline Category & Description & Targeted therapy \\
\hline A & $\begin{array}{c}\text { HER2 or RET aberration or FGFR1 } \\
\text { amplification or FGFR2 mutation or } \\
\text { FGFR3 mutation or any other } \\
\text { aberration that is not in } \mathrm{B}, \mathrm{C}, \mathrm{D}\end{array}$ & $\begin{array}{c}\text { MET mut or amp: Savolitinib } \\
\text { MAP2K 1/2: Vemurafenib + Cobimetinib } \\
\text { BRCA } 1 / 2 \text { or ATM inactivation: Olaparib } \\
\text { FGFR 1/2/3: AZD4547 } \\
\text { RET translocation: Vandetanib }\end{array}$ \\
\hline B & $\begin{array}{c}\text { No HER2, RET, FGFR1-2-3, LKB1 } \\
\text { aberration, but KRAS or BRAF } \\
\text { mutation }\end{array}$ & Selumetinib \\
\hline C & $\begin{array}{c}\text { No HER2, RET, FGFR1-2-3, LKB1, } \\
\text { KRAS, BRAF aberration, but PIK3CA } \\
\text { mutation or PIK3CA amplification or } \\
\text { PTEN loss or PTEN mutation or AKT1 } \\
\text { mutation }\end{array}$ & AZD5363 \\
\hline D & $\begin{array}{c}\text { No HER2, RET, FGFR1-2-3, KRAS, } \\
\text { BRAF, PIK3CA, PTEN or AKT1 } \\
\text { aberration, but } L K B 1 \text { mutation }\end{array}$ & AZD2014 \\
\hline
\end{tabular}

Supplementary Table 2: Classification of targetable molecular alterations by the molecular tumor board 


\section{Acknowledgments}

We thank the patients and their families as well as all of the investigators and their staff involved in SAFIR02-LUNG trial.

We are grateful to the members of the Independent Data Monitoring Committee: Pr Nicholas

TURNER, Pr Sibylle LOIBL, Dr Sylvia NOVELLO, Dr Enriqueta FELIP, Ms Saskia LITIERE, Ms Delphine BELTRAM.

We thank IFCT for its expertise and advice in thoracic oncology throughout the study.

The study was funded by Fondation ARC and an Investigator Sponsored Study Program supported by AstraZeneca. AstraZeneca also supported the duvalumab supply to the study sites. 


\section{Résumé}

Introduction : Le cancer bronchique reste le premier pourvoyeur de métastases cérébrales (MC), responsables d'une importante morbidité et mortalité. De plus, la réponse cérébrale aux traitements systémiques est inconstante et imprévisible du fait de plusieurs phénomènes. Tout d'abord, bien que les spécificités moléculaires et phylogéniques des métastases cérébrales soient toujours largement inconnues, on observe une hétérogénéité significative entre les métastases cérébrales et la tumeur primitive, suggérant l'existence d'un précurseur commun acquérant par la suite des altérations moléculaires. Les spécificités de la barrière hémato-encéphalique et les particularités du microenvironnement cérébral contribuent également au caractère inconstant de la réponse cérébrale. Nous avons mené une étude à partir des données de l'essai de phase II randomisé SAFIR-02 Lung. Notre objectif principal était de comparer les profils moléculaires des patients avec et sans MC. Notre objectif secondaire était d'évaluer la réponse intra-cérébrale en fonction du traitement de maintenance reçu, et du statut cérébral à l'inclusion.

Méthodes: Un total de 365 patients screenés dans l'essai SAFIR-02 Lung disposant de données moléculaires interprétables ont été inclus dans cette analyse. Les données cliniques et biologiques ont été recueillies. Les analyses génomiques reposaient sur la l'hybridation génomique comparative et le séquençage de nouvelle génération (NGS) suivant les recommandations du protocole.

Résultats : Les analyses génomiques initiales ont permis d'identifier une signature de 12 gènes (renforcée par 12 gènes adjacents), spécifique des cancers bronchiques avec MC. Tous les gènes identifiés avaient été précédemment décrits comme impliqués dans l'oncogenèse (TNS1, PAK2, COBL, CDK5, GLRX3, WNT5B, SETD1B, EGLN3, TOX3, RYR1, PVR et BCL2LL1). Les analyses en NGS ont retrouvé une proportion plus importante de mutations de KRAS dans le groupe porteur de métastases cérébrales (44,3\% versus $32,3 \%$ ), particulièrement de mutation G12C (63\% versus $47 \%$ ). De plus, I'analyse des interactions protéiques a mis en évidence plusieurs interactions centrées autour d'EGFR, apparaissant comme un driver de prolifération cérébrale malgré l'exclusion des mutations activatrices. Par ailleurs, le risque de progression cérébrale était réduit dans le bras traité par pemetrexed. Le taux le plus élevé de progression cérébrale était observé dans le bras traité par durvalumab.

Conclusion : Ce travail a identifié une signature de 24 gènes spécifique des cancers bronchiques avec MC. De futures études seront nécessaires pour préciser les implications fonctionnelles de ces gènes et mieux comprendre le processus métastatique cérébral dans l'objectif d'identifier, à partir de cette signature, de nouvelles cibles thérapeutiques pour la prise en charge des cancers bronchiques avec MC. 


\section{Introduction}

Le cancer bronchique non à petites cellules (CBNPC) métastatique reste la première cause de décès par cancer dans le monde $(1,2)$, notamment du fait de la grande incidence des métastases cérébrales (MC) (3). En effet, le cancer bronchique est le premier pourvoyeur de MC, représentant environ $50 \%$ des atteintes cérébrales secondaires. Les MC sont retrouvées dans environ $10 \%$ des cas au diagnostic de CBNPC, et dans jusqu'à $50 \%$ des cas tout au long de l'évolution de la maladie (4). Malgré les progrès majeurs des traitements locaux et systémiques ces dix dernières années, les MC du CBNPC sont toujours responsables d'une morbidité et d'une mortalité importante avec une survie globale (SG) n'excédant pas 12 mois (5). De plus, la toxicité des traitements locaux peut avoir un impact important sur la qualité de vie et ne doit pas être négligée (6). En conséquence, il est nécessaire d'améliorer les connaissances sur la biologie des MC dans le but d'améliorer encore le pronostic du CBNPC.

Bien que les mécanismes cellulaires sous-tendant la dissémination métastatique soient désormais bien connus, les spécificités génomiques et phylogéniques de l'invasion cérébrale restent peu connues. Le démembrement moléculaire progressif du cancer bronchique a permis de mettre en évidence une association entre certaines altérations moléculaires et une forte $(A L K, E G F R)$ (7) ou une faible (KRAS) (8) incidence des MC, suggérant l'implication de caractéristiques moléculaires dans l'invasion du système nerveux central. Bien que rares, les données déjà publiées sur la biologie des MC suggèrent une hétérogénéité moléculaire significativement plus importante dans tissu métastatique cérébral, comparativement aux lésions primitives ou aux autres sites métastatiques (9). Par exemple, Jiang et al. ont récemment rapporté des données retrouvant une hétérogénéité moléculaire significativement plus importante dans les $M C$ comparativement à la tumeur primitive (médiane de 6,8\% de mutations partagées) mais également aux métastases hépatiques (médiane de 66,3\% de mutations partagées; $p=0,005$ ) (10). De plus, les reconstructions phylogéniques basées sur ces données soulevaient la précocité du processus métastatique cérébral par rapport aux autres lésions à distance. Ces données génomiques spécifiques aux MC ont été confirmées et approfondies dans une étude publiée récemment par notre équipe, qui a permis d'identifier des mutations récurrentes dans 13 gènes ( $A F F 2, A N O 3, C C D C 178$, CRISP3, DRD5, FAM134A, LOR, NCOR2, NELFB, RUNX1T1, SPATA31C1 et TENM3), qui n'étaient 
jamais identifiées dans les tumeurs primitives bronchiques (11). Bien que la barrière hématoencéphalique (BHE) soit certainement impliquée dans ces divergences moléculaires (12), ces données sont un argument fort pour supposer l'existence d'un précurseur commun à la tumeur primitive bronchique, aux MC et aux autres lésions à distance, évoluant par la suite pour leur propre compte. Au cours de cette évolution, le nombre de mutations et d'altérations chromosomiques acquises semblait plus important dans les MC que dans les lésions primitives ou les autres sites métastatiques (10). Toutefois, les interactions entre les spécificités moléculaires des MC et l'efficacité intracérébrale des traitements systémiques n'ont que peu été explorées jusqu’à présent.

De plus, l'efficacité intracérébrale des traitements systémiques reste largement imprévisible, notamment car les patients porteurs de MC symptomatiques sont le plus souvent exclus des essais cliniques, mais également du fait des modifications pharmacodynamiques et pharmacocinétiques engendrées par la BHE (13). Dans ce contexte, la morbi-mortalité liée aux MC est encore accentuée par le caractère souvent dissocié de la réponse intra et extra-cérébrale aux traitements systémiques. Dans le CBNPC, l'adjonction d'un traitement anti-angiogénique (Bevacizumab, anticorps monoclonal anti-VEGF) à un doublet standard à base de de sel de platine a été le premier régime à suggérer une amélioration de l'efficacité intracérébrale (5). Par la suite, malgré une incidence plus importante des MC chez les patients porteurs d'une mutation activatrice de l'EGFR ou d'un réarrangement $A L K$, l'excellente efficacité intracérébrale des inhibiteurs de tyrosine kinase de nouvelle génération, particulièrement de l'osimertinib et de l'alectinib, ont réussi à transformer des patients atteints de MC en longs-répondeurs $(14,15)$. Pour finir, l'efficacité intracérébrale des inhibiteurs de points de contrôles immunitaires $(\mathrm{ICI})$ reste très imprévisible, d'une part du fait de la fréquente utilisation concomitante de corticostéroïdes (16), mais également à cause des particularités immunitaires du système nerveux central, comme l'absence de lymphocytes T cytotoxiques ou l'implication fonctionnelle des astrocytes (17).

En tenant compte de ces particularités, une meilleure connaissance de la biologie des MC sera essentielle pour continuer à améliorer le pronostic du cancer bronchique. Etant donné les contraintes techniques liées à la réalisation d'analyses moléculaires sur des échantillons de $M C$ en routine clinique, l'identification d'une signature génomique spécifique de la 
présence de $\mathrm{MC}$ à partir de la tumeur primitive ou des métastases à distance pourrait aider à améliorer la prise en charge de ces patients. De plus, l'enrichissement des connaissances concernant l'efficacité intracérébrale des différents traitements systémiques (chimiothérapies, thérapies ciblées, $\mathrm{ICI}$ ) sera primordial pour améliorer la prise en charge des MC. Nous avons mené une étude ancillaire de l'essai de phase II randomisé SAFIR-02 Lung (18) (Essai intergroupe Unicancer 0105-1305/IFCT1301 SAFIR02 Lung - NCT02117167), comportant des données cliniques et biologiques exhaustives de patients atteints de CBNPC métastatique, mais également des données d'efficacité sous divers régimes de traitement de maintenance (chimiothérapie, thérapie ciblée, ICI). L'objectif principal de ce travail était de comparer les particularités moléculaires (mutations et variations du nombre de copies) de CBNPC avec et sans MC dans le but d'établir une signature spécifique des MC de cancer bronchique. L'objectif secondaire était d'évaluer l'efficacité intracérébrale des différents traitements de maintenance en fonction du statut cérébral à l'inclusion. 


\section{Matériel et Méthodes}

\section{Essai SAFIR-02 Lung}

L'essai de phase II multicentrique randomisé SAFIR-02 Lung a inclus 999 patients atteints de CBNPC de stade avancé et naïfs de traitement. Les autres critères d'inclusion principaux étaient l'absence d'altération activatrice d'EGFR ou $A L K$, la disponibilité d'un échantillon tissulaire issu de la tumeur primitive ou d'une métastase à distance (hors échantillon osseux) utilisable pour la réalisation d'analyses moléculaires et l'éligibilité à un traitement de première ligne standard par un doublet à base de sel de platine. Les patients inclus devaient avoir présenté une réponse partielle ou une stabilité de la maladie selon RECIST 1.1 après la chimiothérapie d'induction. Les critères d'exclusion pouvaient être résumés à toutes les contre-indications éventuelles à une des drogues de l'étude (l'ensemble des critères d'inclusion et d'exclusion sont détaillés dans l'Annexe 1). Concernant le statut cérébral, seules les MC symptomatiques ou en progression après la chimiothérapie d'induction étaient considérées comme un critère d'exclusion. Conformément au protocole de l'étude, une IRM ou un scanner cérébral était requis pour l'inclusion. Au cours du suivi, une imagerie cérébrale était nécessaire pour les patients porteurs de $M C$ à l'inclusion ou en cas de symptômes neurologiques.

Cet essai ouvert reposait sur une analyse génomique à haut débit comme outil de la décision thérapeutique dans le but de comparer un traitement de maintenance expérimental (bras A) à un traitement de maintenance standard (bras B) : une thérapie ciblée (Annexe 2) versus un traitement standard si une altération moléculaire était identifiée (sous-étude 1 175 patients randomisés) ou une immunothérapie par durvalumab (anti-PDL1) versus un traitement standard en l'absence d'altération moléculaire ciblable ou de contre-indication à une des thérapies ciblées (sous-étude 2 - 183 patients randomisés). Le bras traitement de maintenance standard reposait sur le pemetrexed pour les CBNPC non-épidermoïdes et sur l'erlotinib pour les CBNPC épidermoïdes. L'éligibilité à la sous-étude 1 était définie par l'existence d'une altération moléculaire ciblable selon l'avis du molecular tumor board (MTB), qui séparait les altérations moléculaires en 4 catégories (Annexe 2). Dans le cas contraire, les patients étaient éligibles à la randomisation dans la sous-étude 2. La randomisation était basée sur un ratio 2:1 en faveur du traitement expérimental dans chaque sous-étude. 


\section{Population de l'étude}

Les patients étaient sélectionnés à partir de l'essai SAFIR-02 Lung, notre étude suivait donc les critères d'inclusion et d'exclusion de l'essai (Annexe 1). Pour notre objectif principal, tous les patients screenés dans l'étude étaient éligibles, et tous les patients randomisés étaient éligibles pour notre objectif secondaire, sous réserve de la disponibilité de données moléculaires de qualité suffisante pour les analysés prévues.

Le statut métastatique cérébral à l'inclusion a été recueilli à partir du formulaire de collecte de données prévu par l'étude, et l'évolution intracérébrale sous traitement a été évaluée par relecture des images par l'investigateur, basée sur les imageries de suivi prévues dans de cadre de l'essai (imagerie cérébrale par scanner ou IRM en cas de lésions cérébrales à l'inclusion ou de symptômes neurologiques) et était définie comme l'apparition d'une lésion cérébrale sous traitement, indépendamment du statut cérébral à l'inclusion.

\section{Analyses génomiques}

Pour l'inclusion, une biopsie archivée ou un nouveau prélèvement réalisé avant le troisième cycle de chimiothérapie était nécessaire et devait être envoyé à une des cinq plateformes génomiques de l'essai (Gustave Roussy, Centre Léon Bérard, Institut Bergonié, Institut de Cancérologie de l'Ouest) pour extraction d'ADN, contrôle qualité et analyses génomiques (hybridation génomique comparative ( $\mathrm{CGH}$ array) et séquençage de nouvelle génération (NGS)). Les analyses étaient réalisées préférentiellement sur tissu congelé mais étaient également faisables sur échantillon fixé en paraffine (FFPE). Les analyses moléculaires étaient possibles pour une proportion de cellules tumorales supérieure à $30 \%$ pour les échantillons congelés et supérieure à $10 \%$ pour les échantillons FFPE. Pour les lames de tissu FFPE ( 6 coupes de $6 \mu \mathrm{m}$ chacune), les régions riches en cellules tumorales étaient disséquées puis digérées à la protéinase $\mathrm{K}$ avant extraction d'ADN par le kit Maxwell RSC DNA FFPE (Promega) ou le kit QIAmp DNA FFPE tissue (Qiagen). L'extraction d'ADN des échantillons congelés était réalisée avec le kit AllPrep DNA/RNA Mini (Qiagen) conformément aux instructions du constructeur. L'ADN était quantifié grâce à la technologie fluorométrique Qubit 2.0 (Thermo Fisher Scientific). En l'absence d'ADN tissulaire disponible, un prélèvement d'ADN tumoral circulant pouvait être réalisé pour les analyses moléculaires, extrait grâce au kit QIAmp Circulating Nucleic Acid (Qiagen). 
Le panel NGS incluait 65 gènes, oncogènes connus ou suppresseurs de tumeurs. La première étape de réaction en chaine par polymérase $(P C R)$ était réalisée à partir d'un échantillon d'ADN de $10 \mathrm{ng}$. Les amplicons étaient ensuite digérés partiellement pour se débarrasser des séquences primer avant ligation avec les codes-barres correspondants; amplification puis purification. Après le contrôle qualité et quantité des échantillons et le regroupement des libraires, le séquençage était réalisé grâce à la technologie lonTorrentS5 ou Illumina Miseq. Les analyses de CGH-array étaient réalisées sur une plateforme Affymetrix grâce au kit CytoScan HD array pour l'ADN extrait des échantillons congelées et grâce au kit OncoScan FFPE Assay pour l'ADN extrait des échantillons FFPE. Les deux technologies utilisaient des sondes repérant le polymorphisme d'un seul nucléotide pour évaluer les variations du nombre de copies d'ADN. Les données génomiques étaient systématiquement analysées par le MTB pour confirmer la pathogénicité des variants identifiés et donc l'éligibilité des patients à la sous-étude 1 .

\section{Analyses bio-informatiques}

Pour l'analyse des données de NGS, tous les variants dépassant les seuils suivants ont été sélectionnés : profondeur de couverture d'au moins 100X, ratio allélique supérieur à $5 \%$ et fréquence inférieure à $0,1 \%$ dans $1000 \mathrm{~g}$, ESP et gnomAD. Toutes les mutations somatiques ont été annotées, triées et interprétées par un spécialiste en biologie moléculaire en accord avec les bases de données actuelles (Cosmic, TumorPortal, TCGA, Cancer Hotspots...). Les variants pathogènes étaient décrits comme suit : (i) pour les oncogènes, seules les mutations entrainant en gain de fonction étaient considérées (mutation faux-sens dans un hotspot, insertions/délétions/altération d'épissage dans le cadre de lecture, décrits comme oncogènes dans la littérature), (ii) pour les gènes suppresseurs de tumeurs, seules les mutations responsables d'une perte de fonction étaient considérées (toutes les altérations tronquantes ou les mutations faux-sens précédemment décrites comme délétères dans la littérature).

Pour les analyses en CGH-array, les variations du nombre de copies obtenues par CytoScan et OncoScan ont été mesurées avec le paquet rCGH sur R (v1.16.0 sur R v3.6.3). Des ratios relatifs logarithmiques ( $\log 2)$ ont été calculés avant centralisation du profil pour établir le niveau de base à partir duquel les variations du nombre de copies étaient estimées (2 copies étant considéré comme le niveau neutre). Les points de cassure dans la continuité du ratio logarithmique ont été identifiés par segmentation des profils. Ces segments étaient utilisés 
pour détecter des amplifications focales ( $\log 2$ ratio $>1,58$ i.e. $>6$ copies d'ADN; taille des amplicons $<10 \mathrm{Mb}$ ) ou des délétions homozygotes ( $\log 2$ ratio <-1) qui étaient ensuite discutés à l'occasion du MTB. Les amplifications focales et les délétions homozygotes étaient comparées parmi les groupes prédéfinis et une $p$-value $<0,05$ avant ajustement était considérée comme statistiquement significative. La recherche de driver oncogéniques parmi les régions d'intérêt reposait sur deux approches différentes. Tout d'abord, la stratégie candidate présumait que le gène candidat avait été précédemment décrit comme altération somatique connue dans le cancer bronchique (sélection de 23 gènes) (19). Ensuite, chaque driver potentiel était évalué selon la stratégie découverte, qui consistait à documenter chaque gène candidat parmi les bases de données oncoKB et Pubmed. Les analyses en CGH-array ont été volontairement limitées aux amplifications focales et aux délétions homozygotes, car ce sont les seules dont on connait l'impact théranostique.

\section{Analyses statistiques}

Les données ont été résumées par leur fréquence et leur pourcentage pour les variables catégorielles et par leur médiane et leurs bornes pour les variables continues. Les comparaisons entre les groupes ont été réalisées grâce au test de Wilcoxon (somme de rangs) pour les variables continues et grâce au test $d u \mathrm{Chi}^{2}$ ou au test exact de Fisher pour les variables catégorielles. Toutes les analyses statistiques étaient réalisées de façon bilatérale, et les différences identifiées étaient considérées comme statistiquement significatives pour une $p$-value $<0,05$. Les analyses statistiques ont été réalisées grâce au logiciel $\mathrm{R}$ version 3.6.3. La procédure de Benjamini-Hochberg a été utilisée pour corriger les $p$-values au fur et à mesure des tests réalisés pour les analyses NGS. Elle fait partie des corrections de type FDR (False Discovery Rate).

\section{Encadrement éthique}

L'essai SAFIR-02 Lung a été approuvé par le comité d'éthique français (CPP lle de France 2) le 09 Novembre 2013 (2013-08-04) et par les autorités sanitaires (ANSM) le 17 Octobre 2013 (130975A-12). L'essai SAFIR-02 Lung a été conduit en accord avec la déclaration d'Helsinki et les recommandations actuelles du Conseil International d'Harmonisation des exigences techniques pour l'enregistrement des médicaments à usage humain ainsi que toutes les autres réglementations applicables. Les patients inclus ont tous signé un 
consentement éclairé pour le prélèvement tissulaire, la randomisation et l'utilisation de leur données biologiques à des fins de recherche. Concernant notre étude, tous les patients ont signé un consentement éclairé pour des études ancillaires au protocole SAFIR-02 Lung, et un contrat de licence a été établi pour déterminer le cadre de l'utilisation des données par les investigateurs (RCAPHM14 0097). 


\section{Résultats}

\section{Population}

L'inclusion des patients s'est déroulée d'Avril 2014 à Décembre 2018 dans 37 centres en France. Parmi les 999 patients inclus, le statut cérébral initial était connu pour 785 patients, et 365 d'entre eux disposaient de données génomiques de qualité et de quantité suffisante pour être inclus dans notre étude. Les données de CGH-array ont été collectées pour les 365 patients inclus et les données de NGS pour 360 d'entre eux (5 patients exclus en raison de la qualité insuffisante du matériel tumoral disponible). La population a d'abord été divisée en deux groupes en fonction du statut métastatique cérébral à l'inclusion, et retrouvait 107 patients présentant des métastases cérébrales initiales, dont 67 avec au moins deux lésions. Parmi les 107 patients du groupe MC-positif, 47 (44\%) ont bénéficié d'un traitement local cérébral par radiothérapie avant le début de la chimiothérapie. Les caractéristiques des patients sont résumées dans le Tableau 1, et ont permis de mettre en évidence une proportion plus élevée de patients tabagiques actifs dans le groupe MC-positif (58,9\% versus 44,3\% $p<0,005)$. 


\begin{tabular}{|c|c|c|c|}
\hline Caractéristiques & $\begin{array}{c}\text { Groupe } \\
\text { MC-positif } \\
(\mathrm{N}=107)\end{array}$ & $\begin{array}{c}\text { Groupe MC- } \\
\text { négatif } \\
(\mathrm{N}=\mathbf{2 5 8})\end{array}$ & $p$-value \\
\hline Âge (bornes) & $64,1(33,0-80,9)$ & $58,9(32,7-83,8)$ & $p=0,116$ \\
\hline \multicolumn{4}{|l|}{ Sexe } \\
\hline Masculin & $60(56,1 \%)$ & $167(64,7 \%)$ & \multirow[t]{2}{*}{$p=0,152$} \\
\hline Féminin & $47(43,9 \%)$ & $91(35,3 \%)$ & \\
\hline \multicolumn{4}{|l|}{ Statut tabagique } \\
\hline Tabagique actif & $63(58,9 \%)$ & $114(44,2 \%)$ & \multirow{4}{*}{$p<0,05$} \\
\hline Ancien tabagique & $31(29,0 \%)$ & $119(46,1 \%)$ & \\
\hline Non-fumeur & $11(10,2 \%)$ & $23(8,9 \%)$ & \\
\hline Manquant & $2(1,9 \%)$ & $2(0,8 \%)$ & \\
\hline \multicolumn{4}{|l|}{ Histologie } \\
\hline Non-épidermoïde & 107 (100\%) & $258(100 \%)$ & \\
\hline Épidermoïde & $0(0 \%)$ & $0(0 \%)$ & \\
\hline \multicolumn{4}{|l|}{ Stade initial } \\
\hline 1 & $2(1,9 \%)$ & $2(0,8 \%)$ & \multirow{4}{*}{$p=0,053$} \\
\hline II & $0(0 \%)$ & $1(0,4 \%)$ & \\
\hline III & $0(0 \%)$ & $15(5,8 \%)$ & \\
\hline IV & $105(98,1 \%)$ & $240(93,0 \%)$ & \\
\hline $\begin{array}{c}\text { Nombre médian de sites } \\
\text { métastatiques }\end{array}$ & $4(1-9)$ & $3(1-9)$ & $p<0,05$ \\
\hline Patients randomisés & $47(43,9 \%)$ & $106(41,1 \%)$ & \multirow{3}{*}{$p=1,00$} \\
\hline Sous-étude 1 & $32(68,1 \%)$ & $73(68,9 \%)$ & \\
\hline Sous-étude 2 & $15(31,9 \%)$ & $33(31,1 \%)$ & \\
\hline \multicolumn{4}{|l|}{ Traitement de $\mathbf{1}^{\text {ère }}$ ligne } \\
\hline Platine/Pemetrexed & $95(88,8 \%)$ & $223(86,5 \%)$ & \multirow{5}{*}{$p=0,060$} \\
\hline Platine/Paclitaxel & $4(3,7 \%)$ & $23(8,9 \%)$ & \\
\hline Platine/Vinorelbine & $1(0,9 \%)$ & $0(0 \%)$ & \\
\hline Platine/Gemcitabine & $0(0 \%)$ & $4(1,5 \%)$ & \\
\hline Autre & $7(6,6 \%)$ & $8(3,1 \%)$ & \\
\hline
\end{tabular}

Tableau 1 : Caractéristiques des patients à l'inclusion en fonction du statut cérébral initial 


\section{Analyses initiales de CGH-array}

Les amplifications focales les plus fréquemment retrouvées étaient localisées en $5 p 15.33$ (TERT), 8q24.21 (MYC) et 14q13.3 (NKX2-1) à la fois dans le groupe MC-positif et dans le groupe MC-négatif. La stratégie candidate n'a pas permis d'identifier d'amplification focale associée de façon significative au statut cérébral. Avec la stratégie découverte, une variation significative d'amplifications focales a pu être identifiée dans 12 gènes (et 12 gènes adjacents) entre le groupe MC-positif et le groupe MC-négatif (Tableau 2 et Figure 1a). A l'exception $\mathrm{d}^{\prime} E G L N 3$ (et le gène adjacent NFKBIA), les amplifications focales étaient toutes en faveur du groupe MC-positif. L'amplification focale du gène BCL2L1 est illustrée dans la Figure 1b. Les 12 gènes identifiés ont tous été précédemment décrit comme impliqués dans le processus oncogénique. En revanche, aucune des deux stratégies (candidate ou découverte) n'a pu identifier de délétion homozygote significativement associée au statut cérébral.

\begin{tabular}{|c|c|c|c|c|c|c|}
\hline \multirow[b]{2}{*}{$\mathrm{Chr}^{+}$} & \multirow[b]{2}{*}{ Région } & \multicolumn{2}{|c|}{ Échantillons avec $\mathrm{AF}^{+\dagger}(\%)$} & \multirow[b]{2}{*}{ Gène } & \multirow{2}{*}{$\begin{array}{c}\text { Gène(s) } \\
\text { adjacent(s) }\end{array}$} & \multirow[b]{2}{*}{$p$-value } \\
\hline & & $\begin{array}{l}\text { Groupe MC- } \\
\text { positif }\end{array}$ & $\begin{array}{l}\text { Groupe MC- } \\
\text { négatif }\end{array}$ & & & \\
\hline 2 & q35 & $3(2,80 \%)$ & $0(0 \%)$ & TNS1 & & 0,039 \\
\hline 3 & q29 & $4(3,73 \%)$ & $0(0 \%)$ & PAK2 & TFRC & 0,010 \\
\hline 7 & p12.1 & $9(8,41 \%)$ & $7(2,71 \%)$ & $C O B L$ & $E G F R$ & 0,032 \\
\hline 7 & q36.1 & $8(7,48 \%)$ & $6(2,32 \%)$ & CDK5 & AGAP3 & 0,042 \\
\hline 10 & q26.3 & $6(5,61 \%)$ & $2(0,77 \%)$ & GLRX3 & MKI67 & 0,013 \\
\hline 12 & $\mathrm{p} 13.33$ & $6(5,61 \%)$ & $2(0,77 \%)$ & WNT5B & RAD52 & 0,013 \\
\hline 12 & $q 24.31$ & $3(2,80 \%)$ & $0(0 \%)$ & SETD1B & & 0,039 \\
\hline 14 & q13.1 & $0(0 \%)$ & $14(5,43 \%)$ & EGLN3 & $N F K B I A$ & 0,031 \\
\hline 16 & q12.1 & $4(3,74 \%)$ & $1(0,39 \%)$ & TOX3 & & 0,044 \\
\hline 19 & q13.2 & $8(7,48 \%)$ & $4(1,55 \%)$ & $R Y R 1$ & MAP4K1/ACTN4 & 0,010 \\
\hline 19 & $q 13.31$ & $6(5,61 \%)$ & $3(1,16 \%)$ & $P V R$ & CEACAM19/BCL3 & 0,034 \\
\hline 20 & $q 11.21$ & $6(5,61 \%)$ & $3(1,16 \%)$ & $B C L 2 L 1$ & TPX2/FGR1B & 0,034 \\
\hline
\end{tabular}

Tableau 2 : Amplifications focales associées au statut métastatique cérébral

$+:$ Chromosome

†+: Amplification focale 

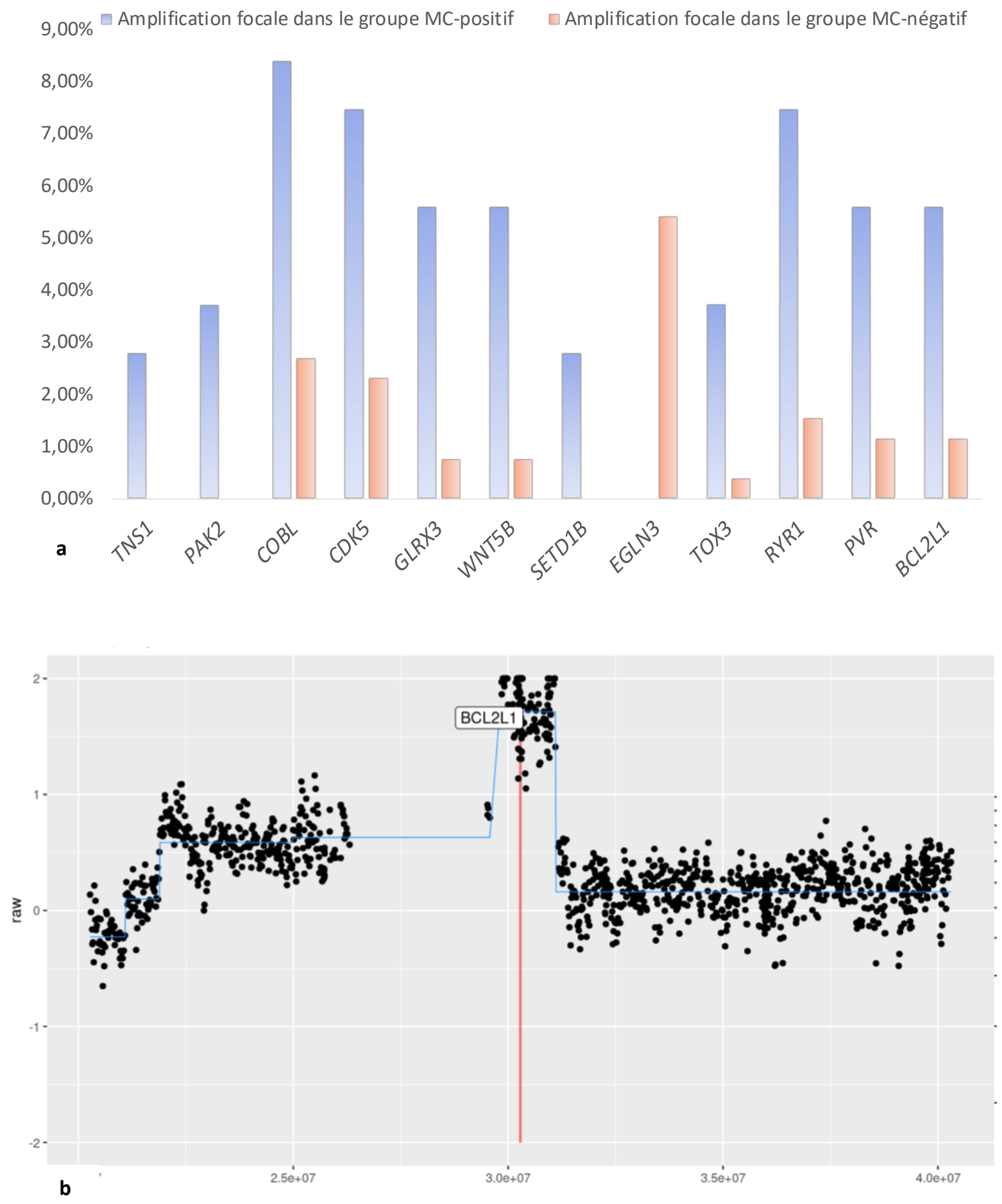

\section{Figure 1 :}

a : Représentation schématique des variations d'amplifications focales entre les groups MCpositif et MC-négatif

b : Illustration d'une amplification focale dans le gène BCL2L1 


\section{Analyse des interactions protéiques}

Pour aller plus loin, nous avons réalisé des analyses d'interactions protéiques grâce à la base de données moléculaire STRING (Search Tool for the Retrieval of Interacting Genes/Proteins) dans le but d'explorer les implications fonctionnelles de la signature moléculaire identifiée. Parmi les 12 gènes sélectionnés, une interaction directe a pu être identifiée uniquement entre les protéines BCL2L1 et TNS1 (co-expression, données expérimentales et données de la littérature). Si les 12 gènes adjacents étaient ajoutés au processus, de nombreuses interactions protéiques étaient retrouvées (Figure 2a), toutes centrées autour d'EGFR. Pour finir, les interactions protéiques entre les 12 gènes identifiés cidessus et la signature de 13 gènes précédemment publiée par notre équipe (11) ont également été explorées. Comme représenté dans la Figure $2 b$, des interactions ont pu être identifiées avec RUNX1T1, NCOR2 et LOR.
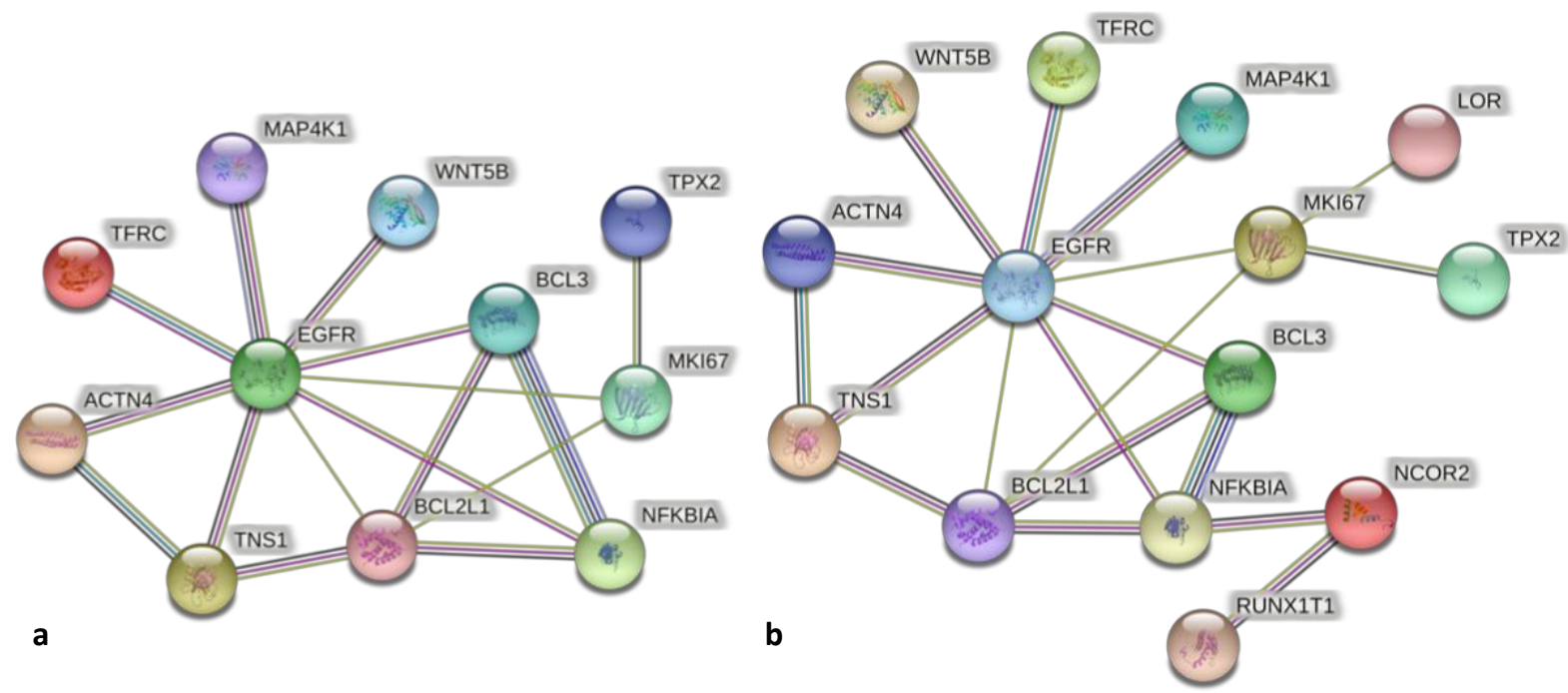

Figure 2 : Réseau d'interactions protéiques entre le produit des 24 gènes identifiés dans cette étude (a) et avec et les 13 gènes de la signature de l'étude pilote (b).

Les interactions sont représentées comme suit :

Trait vert = co-occurrence dans la littérature

Trait noir $=$ co-expression

Trait rose $=$ intéraction expérimentale

Trait bleu = association dans une base de données publique 


\section{Analyses initiales de NGS}

Dans chaque échantillon des deux groupes (MC-positif et MC-négatif), une médiane de 2 variants pathogènes était identifiée (moyenne de 2,16 et 2,25, respectivement). Conformément aux critères définis ci-dessus (profondeur de couverture d'au moins 100X, ratio allélique supérieur à $5 \%$ et fréquence inférieure à $0,1 \%$ dans $1000 \mathrm{~g}$, ESP et gnomAD), 23 gènes du panel ont été sélectionnés pour les analyses de l'étude ( $A T M, B R A F, B R C A 1, B R C A 2$, CTNNB1, EGFR, ERBB2, ERBB3, FBXW7, KEAP1, KRAS, MAP2K1, MAP2K4, MAP3K1, MET, NF1, NFE2L2, NRAS, PIK3CA, PIK3R1, STK11, TP53 et VHL). KRAS et TP53 étaient les deux gènes les plus souvent altérés à la fois dans le groupe MC-positif ( $44,3 \%$ and $43,4 \%$, respectivement) et dans le groupe MC-négatif (32,3\% et 40,2\%, respectivement). En comparant le groupe MCpositif et le groupe MC-négatif, seules les mutations de KRAS se sont avérées être statistiquement associées avec la présence de $M C(p=0,005)$. Une mutation de KRAS était identifiée dans 131 des 360 échantillons analysés (36,4\%), dont 47 dans le groupe MC-positif $(44,3 \%)$ et 84 dans le groupe MC-négatif (33,1\%). La répartition des mutations de KRAS entre les groupes est résumée dans la Figure 3. Nous avons pu observer une prédominance des mutations G12C dans le groupe MC-positif (63\%). Dans le groupe MC-négatif, même si les mutations $\mathrm{G} 12 \mathrm{C}$ restaient dominantes (47\%), nous avons observé une plus grande proportion de mutations KRAS G12V (21\%) et KRAS G12A (12\%).

Mutations de KRAS dans le groupe MC-positif

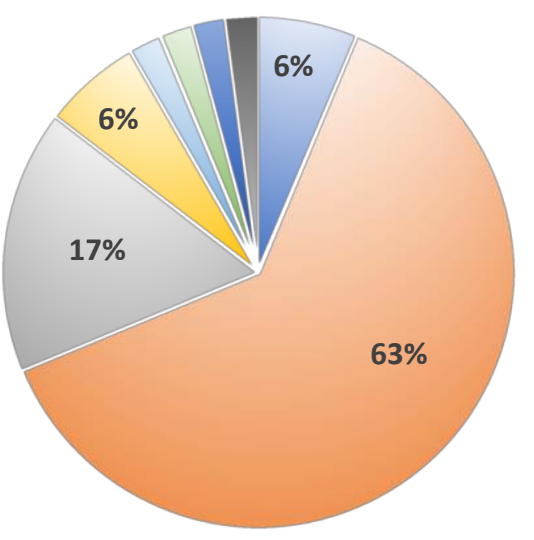

Mutations de KRAS dans le groupe MC-négatif

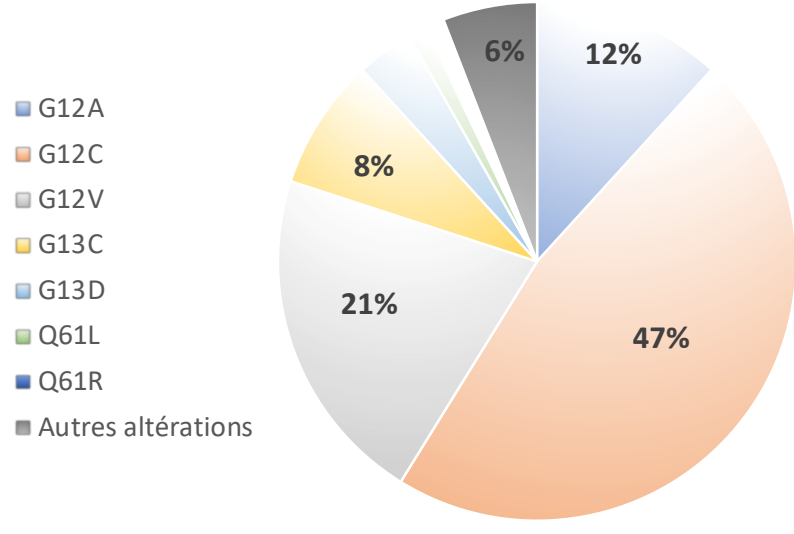

Figure 3 : Répartition des mutations KRAS entre les deux groupes, en fonction du statut cérébral 


\section{Évolution cérébrale pendant la phase de maintenance}

Sur les 365 patients inclus dans notre étude, 153 (41,9\%) ont été randomisés, 47 dans le groupe MC-positif à l'inclusion et 106 dans le groupe MC-négatif à l'inclusion. 137 des 153 patients randomisés $(89,5 \%)$ ont progressé sur le plan radiologique (RECIST 1.1) avant la fin de la collecte des données, prévu après 18 semaines de traitement de maintenance. 40 patients $(85,1 \%)$ du groupe MC-positif et 97 patients $(91,5 \%)$ du groupe MC-négatif ont présenté une progression de leur maladie. Les données de progression cérébrale étaient disponibles pour 124 des 137 patients ayant progressé pendant la maintenance. Une progression intracérébrale a été identifiée pour 17 patients du groupe MC-positif $(44,7 \%)$ et 9 patients du groupe MC-négatif (10,5\%). L'apparition de lésions cérébrales pendant la phase de maintenance en fonction du bras de traitement est résumée dans la Figure 4a. Parmi les 89 patients randomisés dans le bras de traitement expérimental (bras A des sous-études 1 et 2), 20 patients (22,5\%) ont présenté une progression intracérébrale, contre 6 des 35 patients $(17,1 \%)$ randomisés dans le bras de traitement standard (bras B des sous-études 1 et 2). Indépendamment du statut cérébral initial, la proportion de progression intracérébrale la plus importante était identifiée dans le bras durvalumab (sous-étude 2 - bras B) avec 7 patients concernés sur les 25 patients randomisés dans ce bras (28\%) (Figure 4b).

Concernant la répartition des mutations de KRAS, une mutation $\mathrm{G} 12 \mathrm{C}$ était retrouvée chez 8 patients parmi les 12 patients KRAS-mutés ayant présenté une progression cérébrale (66\%). Inversement, les mutations $\mathrm{G} 12 \mathrm{C}$ représentaient 38\% des mutations de KRAS chez les patients qui ne présentaient pas de progression cérébrale (G12V 26\% - G13C 24\%), quel que soit le statut métastatique cérébral initial. 


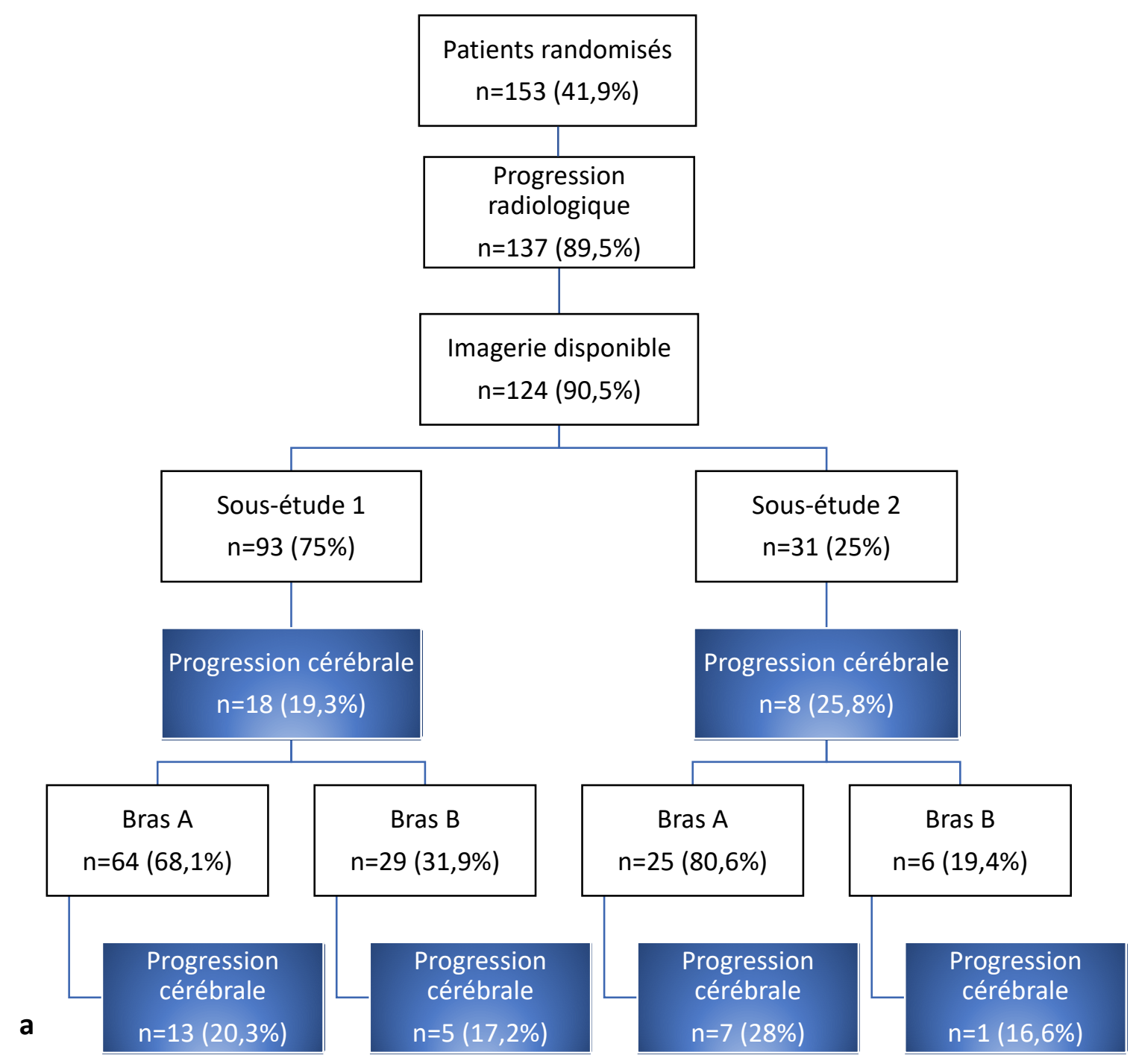

$30 \%$

25

20

15
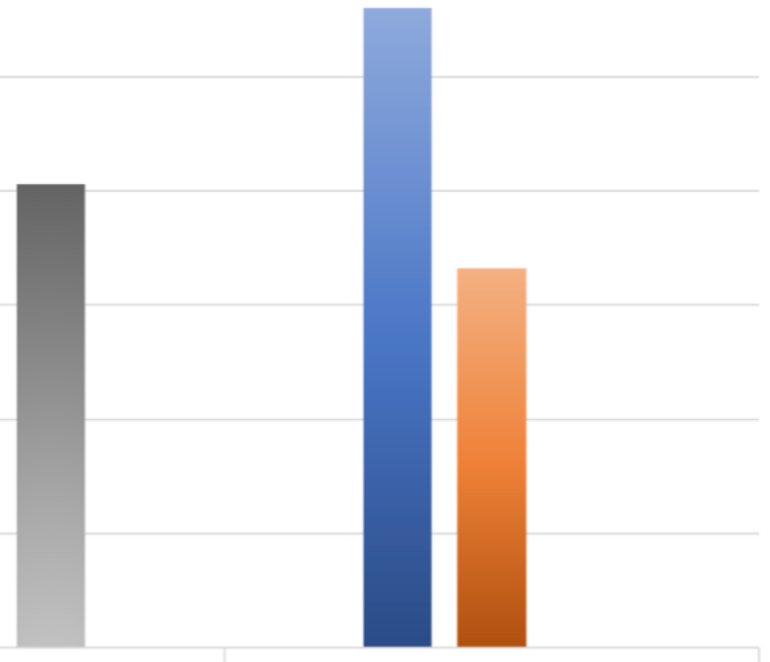

- Durvalumab

Pemetrexed

Thérapie ciblée

b

Sous-étude 1

Sous-étude 2 


\section{Figure 4 :}

a : Diagramme représentant la progression cérébrale en fonction du traitement de maintenance reçu dans le cadre de l'essai

Sous-étude 1 : Présence d’une altération moléculaire ciblable

Bras A : Traitement expérimental par thérapie ciblée

Bras B : Traitement standard par pemetrexed

Sous-étude 2 : Absence d'altération moléculaire ciblable ou contre-indication à la thérapie ciblée indiquée

Bras A : Traitement expérimental par durvalumab

Bras B : Traitement standard par pemetrexed

b : Histogramme représentant la progression cérébrale en fonction du traitement de maintenance reçu 


\section{Discussion}

Connaissant la grande fréquence, morbidité et mortalité liée aux $M C$ de cancer bronchique, il est indispensable de mieux caractériser le profil moléculaire des MC et de mieux comprendre les déterminants de l'efficacité intracérébrale des traitements systémiques. Nous avons mené la plus grande étude à ce jour visant à analyser les spécificités moléculaires des patients atteints de cancer bronchique compliqué de métastases cérébrales. L'analyse comparative des amplifications focales a permis d'identifier une signature de 12 gènes, renforcée par 12 gènes adjacents, statistiquement associée à la présence de métastases cérébrales. La stratégie utilisée pour identifier les différents gènes imposait que tous les gènes soient impliqués dans le processus oncogénique, renforçant ainsi la pertinence clinique de la signature dans le processus de dissémination métastatique cérébral. De plus, des analyses protéiques ont permis de mettre en évidence plusieurs interactions entre les différents gènes identifiés mais également avec plusieurs gènes issus d'une signature moléculaire spécifique du tissu métastatique cérébral précédemment publiée par notre équipe (11). Les principales forces de notre travail sont d'une part le caractère prospectif, randomisé et multicentrique de l'essai SAFIR-02 Lung ainsi que la qualité et la quantité des données moléculaire analysées. De plus, les échantillons étaient extraits de tumeurs bronchiques primitives ou de métastases à distance, et donc représentatifs des échantillons disponibles en routine clinique pour la réalisation des analyses moléculaires.

L'ensemble des 24 gènes identifiés grâce à la stratégie découverte et associés à la présence de $M C$ sont déjà connus comme acteurs du processus oncogénique, et donc probablement impliqués dans l'invasion métastatique cérébrale. L'implication des gènes identifiés dans les principales voies de signalisation nécessaires à l'ongenèse renforce la pertinence clinique de notre signature. Par exemple, TPX2, TNS1 et CEACAM19 sont impliqués dans la voie $\mathrm{PI3K} / \mathrm{AKT} / \mathrm{mTOR}$ et décrits comme associés à l'agressivité tumorale dans de nombreux types tumoraux (20-22). TFRC, codant pour le récepteur de la transferrine TFR1, est un régulateur clef du mécanisme de ferroptose (23). Le rôle de TFR1 a été particulièrement décrit dès les stades précoces de l'oncogenèse cérébrale comme associé à un mauvais pronostic $(24,25)$. MKI67, TNS1, WNT5B et ACTN4 sont décrits dans le processus de prolifération cellulaire 
$(26,27) . R A D 52$ (recombinaison homologue), CDK5 et BCL2L1 sont impliqués dans le processus de réparation de I'ADN et influent donc sur le pronostic de la maladie et la réponse au traitement (28-31). PVR est connu pour faire partie de l'axe TIGIT (point de contrôle immunitaire), et la surexpression de $P V R$ a déjà été décrite comme étant associée à des formes plus agressives de cancer du sein (32). MAP4K1 fait partie de la voie JNK/c-Jun, qui régule l'invasion et la migration cellulaire, et est également décrit comme impliqué dans la résistance au cisplatine (33). Par ailleurs, plusieurs des gènes de la signature sont connus pour être impliqués dans certains processus neurobiologiques. CDK5 est connu pour être un régulateur clef du remodelage du cytosquelette, de la signalisation neuronale et du développement cérébral ; et est impliqués dans plusieurs processus neurodégénératifs (34). AGAP3 est un composant du complexe de récepteurs NMDA qui régulent la signalisation Ras/ERK, ellemême impliquée dans le renforcement synaptique (35). Pour finir, EGLN3, qui promeut la dégradation de HIF, est impliqué dans la normalisation vasculaire et l'invasion gliale (36) ; et la surexpression de $B C L 3$ est associée à la malignité des tumeurs gliales ainsi qu'à une moindre réponse au temozolomide en induisant une transition épithélio-mésenchymateuse (37).

La pertinence biologique de notre signature est encore renforcée par l'analyse des interactions protéiques. En effet, nous avons pu observer le rôle clef d'EGFR comme moteur de la dissémination métastatique cérébrale, bien que les mutations activatrices connues aient été exclues de l'étude. L'analyse des amplifications focales d'EGFR était donc suffisante pour faire ressortir l'association entre l'amplification d'EGFR et la présence de MC initiales. L'identification d'interactions avec plusieurs autres protéines associées à la présence de $M C$ (WNT5B, MAP4K1, TFRC, ACTN4, TNS1, BCL3 et BCL2L1) vient encore renforcer l'implication d'EGFR dans le processus de dissémination métastatique cérébral. En neuro-oncologie, les amplifications d'EGFR sont retrouvées dans plus de $40 \%$ des glioblastomes, et décrites depuis de nombreuses années comme un facteur de progression tumorale précoce $(38,39)$. Les interactions protéiques autour d'EGFR impliquaient essentiellement les voies de réparation de I'ADN ou de prolifération cellulaire, sans co-occurrence claire à ce jour dans la littérature concernant le cancer bronchique ou les tumeurs cérébrales. Nous avons également réussi à identifier plusieurs interactions protéiques entre notre signature (via KI67 et NFKBIA) et les produits de certains gènes précédemment décrits par notre équipe comme préférentiellement altérés dans les échantillons de MC (11). Malgré l'absence d'implication 
claire de $L O R$ dans le processus oncogénique, NCOR2 a déjà été décrit comme un régulateur négatif de la transcription dans les adénocarcinomes bronchiques, et donc comme un régulateur de tumeur tissu-dépendant (40). II n'existe malheureusement aucune donnée sur le rôle éventuel de NCOR2 dans les MC ou les tumeurs cérébrales primitives. Par ailleurs, RUNX1T1 est connu pour être impliqué dans le processus de différentiation neuronale in vitro (41) mais également comme un régulateur épigénétique dans le cancer bronchique à petites cellules (42), en plus d'être impliqué dans le processus métastatique hépatique des tumeurs neuroendocrines pancréatiques (43).

Les analyses de NGS comparatives ont permis de mettre en évidence une plus grande proportion de patients présentant une mutation de KRAS dans le groupe MC-positif. Ce résultat est assez inattendu était donné le rôle protecteur supposé de KRAS vis-à-vis des MC (8). Ce résultat peut être notamment expliqué par la proportion plus importante de patients tabagiques actifs dans le groupe MC-positif mais également par la répartition des mutations de KRAS dans notre étude. En effet, la proportion de mutations $\mathrm{G} 12 \mathrm{C}$ était plus importante dans le groupe MC-positif (63\% versus $47 \%$ ), et encore plus dans le groupe de patients ayant présenté une progression intracérébrale pendant le traitement de maintenance $(73 \%$ versus $38 \%)$. De plus en plus de données concernant la biologie de KRAS relèvent l'association entre la mutation $\mathrm{G} 12 \mathrm{C}$ et une baisse du taux d'AKT phosphorylé comparativement aux autres mutations de KRAS, ce qui entraine par compensation une suractivation de la voie MEK (44). Malgré l'absence de preuve tangible permettant de faire le lien entre cette suractivation de la voie MEK et la dissémination métastatique cérébrale, cette particularité biologique peut cependant expliquer en partie la proportion importante de mutations G12C dans le groupe MC-positif. De plus, les mutations KRAS G12C sont déjà connues pour être de plus mauvais pronostic et associées à une moins bonne réponse aux sels de platine $(45,46)$.

De plus, les données de progression cérébrale sous traitement ont mis en évidence de façon attendue un taux de progression plus important dans le groupe de patients porteurs de MC initiales (44,7\% versus 10,5\%). Bien que la prévalence des MC dans notre étude soit comparable aux données de la littérature (29,3\% dans notre étude versus $26,8 \%$ dans la revue publiée par Cagney DN et al (47)), nous avons observé un taux assez faible de progression intracérébrale lors du traitement de maintenance. Ce résultat peut être expliqué en partie par 
l'exclusion de patients présentant des MC symptomatiques initiales ou en progression au moment de la randomisation. En conséquence, la petite taille de l'échantillon de patients présentant une progression intracérébrale ne nous a pas permis de réaliser d'analyses statistiques dans le but d'identifier les déterminants moléculaires de la progression cérébrale dans chaque bras de traitement. Cependant, nous avons tout de même observé un taux plus faible de progression intracérébrale dans les bras B des sous-études 1 et 2 (bras pemetrexed). La bonne efficacité intracérébrale du pemetrexed a déjà été décrite dans plusieurs essais cliniques en comparaison avec d'autres régimes de chimiothérapie $(48,49)$. Malgré l'efficacité intracérébrale impressionnante des thérapies ciblées de nouvelle génération dans les altérations moléculaires fréquentes, particulièrement $\operatorname{ALK}$ et $\operatorname{EGFR}(50,51)$, nous avons observé un taux discrètement supérieur de progression intracérébrale dans le bras thérapie ciblée de l'étude SAFIR-02 Lung. Ce résultat peut être expliqué par une efficacité systémique moindre des drogues à l'étude, leurs spécificités pharmacocinétiques et pharmacodynamiques ou encore l'agressivité cérébrale associée aux altérations concernées. Pour finir, le taux le plus élevé de progression intracérébrale était observé dans le bras durvalumab de l'essai. Les données d'efficacité intracérébrale des $\mathrm{ICI}$ sont encore rares dans la littérature, les patients atteints de MC étant le plus souvent exclus des essais princeps étant donné l'utilisation fréquente de corticostéroïdes. Dans une étude précédemment publiée par notre équipe, l'efficacité intracérébrale des $\mathrm{ICl}$ semblait dépendre de l'addition d'un traitement cérébral local (chirurgie, radiochirurgie, irradiation stéréotaxique), qui était cependant possible en vue de l'inclusion dans l'essai SAFIR-02 Lung (16). Les déterminants de l'efficacité des ICI devront continuer à être explorés, particulièrement dans le but d'identifier des biomarqueurs prédictifs de la réponse systémique et intracérébrale aux $\mathrm{ICl}$, connaissant la grande spécificité de l'immunité intracérébrale (52). En effet, la microglie assure l'immunité innée cérébrale et les astrocytes représentent les effecteurs adaptatifs du système nerveux central.

Nous avons identifié quelques limites à notre travail. Tout d'abord, la sélection des patients en fonction du statut métastatique cérébral peut manquer de représentativité par rapport aux patients compliqués de MC rencontrés en routine clinique, le plus souvent symptomatiques au moment du diagnostic. Nous pouvons également discuter de l'utilisation d'un panel NGS limité pour les analyses moléculaires, maintenant que les analyses en exome 
entier sont disponibles dans le cadre de la recherche clinique et auraient pu apporter de précieuses informations. Enfin, l'exploration des spécificités moléculaires des $M C$ sans analyser l'échantillon de MC apparié peut être considéré comme une limite scientifique, mais reste cependant plus représentatif du matériel disponible en routine clinique.

Pour aller plus loin, la transposition de ce travail dans une population non sélectionnée traitée en routine et ayant bénéficié d'analyses moléculaires exhaustives pourrait représenter une cohorte de validation intéressante. Ensuite, la réalisation d'analyses fonctionnelles spécifiques aux gènes de la signature identifiée nous permettrait de préciser l'implication des gènes identifiés dans le processus métastatique cérébral. Nous pourrions ainsi déterminer à la fois des cibles thérapeutiques potentielles pour les MC de cancer bronchique pour améliorer le pronostic en cas de dissémination métastatique cérébrale, mais également pour prévenir dans un contexte adjuvant l'apparition de $M C$ en identifiant un profil de susceptibilité moléculaire sur la tumeur primaire. Malgré les progrès biologiques, le tabagisme actif reste un facteur de risque majeur de développement de $M C$, grevant ainsi le pronostic du cancer bronchique, ce qui souligne la place capitale des politiques de lutte contre le tabagisme dans la prise en charge du cancer bronchique.

En conclusion, nous avons mené la plus large étude à ce jour évaluant les déterminants moléculaires associés aux MC de cancer bronchique, et réussi à identifier une signature de 24 gènes dont l'amplification focale était significativement associée au statut cérébral à l'inclusion. Dans le futur, l'identification d'une signature spécifique des MC sur la tumeur primitive pourra aider à prévenir la dissémination cérébrale du CBNPC et ainsi en améliorer encore le pronostic. 


\section{Bibliographie}

1. Barta JA, Powell CA, Wisnivesky JP. Global Epidemiology of Lung Cancer. Ann Glob Health. 22 janv 2019;85(1).

2. Ferlay J, Colombet $\mathrm{M}$, Soerjomataram I, Mathers $\mathrm{C}$, Parkin DM, Piñeros $\mathrm{M}$, et al. Estimating the global cancer incidence and mortality in 2018: GLOBOCAN sources and methods. Int J Cancer. 15 avr 2019;144(8):1941-53.

3. Sperduto PW, Yang TJ, Beal K, Pan H, Brown PD, Bangdiwala A, et al. Estimating Survival in Patients With Lung Cancer and Brain Metastases: An Update of the Graded Prognostic Assessment for Lung Cancer Using Molecular Markers (Lung-molGPA). JAMA Oncol. 1 juin 2017;3(6):827-31. 4. Sørensen JB, Hansen HH, Hansen M, Dombernowsky P. Brain metastases in adenocarcinoma of the lung: frequency, risk groups, and prognosis. J Clin Oncol Off J Am Soc Clin Oncol. sept 1988;6(9):1474-80.

5. Besse B, Le Moulec S, Mazières J, Senellart H, Barlesi F, Chouaid C, et al. Bevacizumab in Patients with Nonsquamous Non-Small Cell Lung Cancer and Asymptomatic, Untreated Brain Metastases (BRAIN): A Nonrandomized, Phase II Study. Clin Cancer Res Off J Am Assoc Cancer Res. 15 avr 2015;21(8):1896-903.

6. Peters S, Bexelius C, Munk V, Leighl N. The impact of brain metastasis on quality of life, resource utilization and survival in patients with non-small-cell lung cancer. Cancer Treat Rev. avr 2016;45:139-62.

7. Rangachari D, Yamaguchi N, VanderLaan PA, Folch E, Mahadevan A, Floyd SR, et al. Brain metastases in patients with EGFR-mutated or ALK-rearranged non-small-cell lung cancers. Lung Cancer Amst Neth. avr 2015;88(1):108-11.

8. Tomasini P, Serdjebi C, Khobta N, Metellus P, Ouafik L, Nanni I, et al. EGFR and KRAS Mutations Predict the Incidence and Outcome of Brain Metastases in Non-Small Cell Lung Cancer. Int J Mol Sci. 18 déc 2016;17(12).

9. Brastianos PK, Carter SL, Santagata S, Cahill DP, Taylor-Weiner A, Jones RT, et al. Genomic Characterization of Brain Metastases Reveals Branched Evolution and Potential Therapeutic Targets. Cancer Discov. nov 2015;5(11):1164-77.

10. Jiang $T$, Fang $Z$, Tang $S$, Cheng R, Li Y, Ren $S$, et al. Mutational Landscape and Evolutionary Pattern of Liver and Brain Metastasis in Lung Adenocarcinoma. J Thorac Oncol. févr 2021;16(2):237-49.

11. Tomasini et al. P. Tomasini, S. Gilles, E. Pellegrino, I. Nanni-Metellus, J.-M. Robitaille, F. Barlesi, L. Ouafik, P. Metellus, Comparative genomic analysis of primary tumors and paired Brain Metastases in lung cancer patients: a whole exome sequencing study, Annu. Brain Metastases Res. Emerg. Ther. (2016) 66-67.

12. Wrobel JK, Toborek M. Blood-brain Barrier Remodeling during Brain Metastasis Formation. Mol Med Camb Mass. sept 2016;22:32-40.

13. Patel MM, Patel BM. Crossing the Blood-Brain Barrier: Recent Advances in Drug Delivery to the Brain. CNS Drugs. févr 2017;31(2):109-33.

14. Reungwetwattana T, Nakagawa K, Cho BC, Cobo M, Cho EK, Bertolini A, et al. CNS Response to Osimertinib Versus Standard Epidermal Growth Factor Receptor Tyrosine Kinase Inhibitors in Patients With Untreated EGFR-Mutated Advanced Non-Small-Cell Lung Cancer. J Clin Oncol Off J Am Soc Clin Oncol. 28 août 2018;JCO2018783118.

15. Gadgeel S, Peters S, Mok T, Shaw AT, Kim DW, Ou SI, et al. Alectinib versus crizotinib in treatment-naive anaplastic lymphoma kinase-positive (ALK+) non-small-cell lung cancer: CNS efficacy results from the ALEX study. Ann Oncol Off J Eur Soc Med Oncol. 01 2018;29(11):2214-22.

16. Bermudez J, Mascaux C, Trigui Y, Biemar J, Boucekine M, Greillier L, et al. Predictive Factors of Intracranial Response of Immune Checkpoint Inhibitors in Patients with Brain Metastasis from Non-Small Cell Lung Cancer. J Cancer Ther. 2019;10(08):692-707. 
17. Vilariño N, Bruna J, Bosch-Barrera J, Valiente M, Nadal E. Immunotherapy in NSCLC patients with brain metastases. Understanding brain tumor microenvironment and dissecting outcomes from immune checkpoint blockade in the clinic. Cancer Treat Rev. sept 2020;89:102067.

18. Barlesi F, Karimi M, Tomasini P, Daniel C, Raimbourg J, Quoix A-E, et al. 1273P Durvalumab (D) compared to maintenance chemotherapy (SoC) in patients (pts) with metastatic non-small cell lung cancer (NSCLC): Results from the randomized SAFIR02 LUNG-IMMUNO trial. Ann Oncol. sept 2020;31:S823.

19. Campbell JD, Alexandrov A, Kim J, Wala J, Berger AH, Pedamallu CS, et al. Distinct patterns of somatic genome alterations in lung adenocarcinomas and squamous cell carcinomas. Nat Genet. juin 2016;48(6):607-16.

20. Zhou F, Wang M, Aibaidula M, Zhang Z, Aihemaiti A, Aili R, et al. TPX2 Promotes Metastasis and Serves as a Marker of Poor Prognosis in Non-Small Cell Lung Cancer. Med Sci Monit Int Med J Exp Clin Res. 4 août 2020;26:e925147.

21. Duan J, Wang L, Shang L, Yang S, Wu H, Huang Y, et al. miR-152/TNS1 axis inhibits non-small cell lung cancer progression through Akt/mTOR/RhoA pathway. Biosci Rep. 29 janv 2021;41(1).

22. Hu X, Chen M, Li Y, Wang Y, Wen S, Jun F. Aberrant CEACAM19 expression is associated with metastatic phenotype in penile cancer. Cancer Manag Res. 2019;11:715-25.

23. Shen Y, Li X, Dong D, Zhang B, Xue Y, Shang P. Transferrin receptor 1 in cancer: a new sight for cancer therapy. Am J Cancer Res. 2018;8(6):916-31.

24. Chirasani SR, Markovic DS, Synowitz M, Eichler SA, Wisniewski P, Kaminska B, et al. Transferrin-receptor-mediated iron accumulation controls proliferation and glutamate release in glioma cells. J Mol Med Berl Ger. févr 2009;87(2):153-67.

25. Weston C, Klobusicky J, Weston J, Connor J, Toms SA, Marko NF. Aberrations in the Iron Regulatory Gene Signature Are Associated with Decreased Survival in Diffuse Infiltrating Gliomas. PloS One. 2016;11(11):e0166593.

26. Zhou H, Zhang Y, Wu L, Xie W, Li L, Yuan Y, et al. Elevated transgelin/TNS1 expression is a potential biomarker in human colorectal cancer. Oncotarget. 2 janv 2018;9(1):1107-13.

27. Jiang S, Zhang M, Zhang $\mathrm{Y}$, Zhou W, Zhu T, Ruan $\mathrm{Q}$, et al. WNT5B governs the phenotype of basal-like breast cancer by activating WNT signaling. Cell Commun Signal CCS. 28 août 2019;17(1):109.

28. Nogueira A, Fernandes M, Catarino R, Medeiros R. RAD52 Functions in Homologous Recombination and Its Importance on Genomic Integrity Maintenance and Cancer Therapy. Cancers. 23 oct 2019;11(11).

29. Liu W, Li J, Song Y-S, Li Y, Jia Y-H, Zhao H-D. Cdk5 links with DNA damage response and cancer. Mol Cancer. 14 mars 2017;16(1):60.

30. Zeng J, Xie S, Liu Y, Shen C, Song X, Zhou G-L, et al. CDK5 Functions as a Tumor Promoter in Human Lung Cancer. J Cancer. 2018;9(21):3950-61.

31. Warren CFA, Wong-Brown MW, Bowden NA. BCL-2 family isoforms in apoptosis and cancer. Cell Death Dis. 21 févr 2019;10(3):177.

32. Stamm H, Oliveira-Ferrer L, Grossjohann E-M, Muschhammer J, Thaden V, Brauneck F, et al. Targeting the TIGIT-PVR immune checkpoint axis as novel therapeutic option in breast cancer. Oncoimmunology. 2019;8(12):e1674605.

33. Bai Y, Liu X, Qi X, Liu X, Peng F, Li H, et al. PDIA6 modulates apoptosis and autophagy of nonsmall cell lung cancer cells via the MAP4K1/JNK signaling pathway. EBioMedicine. avr 2019;42:311-25.

34. Shah K, Rossie S. Tale of the Good and the Bad Cdk5: Remodeling of the Actin Cytoskeleton in the Brain. Mol Neurobiol. avr 2018;55(4):3426-38.

35. Oku Y, Huganir RL. AGAP3 and Arf6 regulate trafficking of AMPA receptors and synaptic plasticity. J Neurosci Off J Soc Neurosci. 31 juill 2013;33(31):12586-98.

36. Sciorra VA, Sanchez MA, Kunibe A, Wurmser AE. Suppression of glioma progression by Egln3. PloS One. 2012;7(8):e40053.

37. Wu L, Bernal GM, Cahill KE, Pytel P, Fitzpatrick CA, Mashek $\mathrm{H}$, et al. BCL3 expression 
promotes resistance to alkylating chemotherapy in gliomas. Sci Transl Med. 4 juill 2018;10(448). 38. Brennan CW, Verhaak RGW, McKenna A, Campos B, Noushmehr H, Salama SR, et al. The somatic genomic landscape of glioblastoma. Cell. 10 oct 2013;155(2):462-77.

39. Eskilsson E, Røsland GV, Solecki G, Wang Q, Harter PN, Graziani G, et al. EGFR heterogeneity and implications for therapeutic intervention in glioblastoma. Neuro-Oncol. 18 mai 2018;20(6):743-52.

40. Alam H, Li N, Dhar SS, Wu SJ, Lv J, Chen K, et al. HP1Y Promotes Lung Adenocarcinoma by Downregulating the Transcription-Repressive Regulators NCOR2 and ZBTB7A. Cancer Res. 15 juill 2018;78(14):3834-48.

41. Zou L, Li H, Han X, Qin J, Song G. Runx1t1 promotes the neuronal differentiation in rat hippocampus. Stem Cell Res Ther. 22 avr 2020;11(1):160.

42. He T, Wildey G, McColl K, Savadelis A, Spainhower K, McColl C, et al. Identification of RUNX1T1 as a potential epigenetic modifier in small-cell lung cancer. Mol Oncol. janv 2021;15(1):195-209.

43. Nasir A, Helm J, Turner L, Chen D-T, Strosberg J, Hafez N, et al. RUNX1T1: a novel predictor of liver metastasis in primary pancreatic endocrine neoplasms. Pancreas. mai 2011;40(4):627-33.

44. Friedlaender A, Drilon A, Weiss GJ, Banna GL, Addeo A. KRAS as a druggable target in NSCLC: Rising like a phoenix after decades of development failures. Cancer Treat Rev. avr 2020;85:101978.

45. Ihle NT, Byers LA, Kim ES, Saintigny P, Lee JJ, Blumenschein GR, et al. Effect of KRAS oncogene substitutions on protein behavior: implications for signaling and clinical outcome. J Natl Cancer Inst. 8 févr 2012;104(3):228-39.

46. Ferrer I, Zugazagoitia J, Herbertz S, John W, Paz-Ares L, Schmid-Bindert G. KRAS-Mutant nonsmall cell lung cancer: From biology to therapy. Lung Cancer Amst Neth. oct 2018;124:53-64.

47. Cagney DN, Martin AM, Catalano PJ, Redig AJ, Lin NU, Lee EQ, et al. Incidence and prognosis of patients with brain metastases at diagnosis of systemic malignancy: a population-based study. Neuro-Oncol. 19 oct 2017;19(11):1511-21.

48. Moro-Sibilot D, Smit E, de Castro Carpeño J, Lesniewski-Kmak K, Aerts JG, Villatoro R, et al. Non-small cell lung cancer patients with brain metastases treated with first-line platinum-doublet chemotherapy: Analysis from the European FRAME study. Lung Cancer. déc 2015;90(3):427-32.

49. Yu X, Fan Y. Effect of pemetrexed on brain metastases from nonsmall cell lung cancer with wild-type and unknown EGFR status. Medicine (Baltimore). janv 2019;98(3):e14110.

50. Tomasini P, Egea J, Souquet-Bressand M, Greillier L, Barlesi F. Alectinib in the treatment of ALK-positive metastatic non-small cell lung cancer: clinical trial evidence and experience with a focus on brain metastases. Ther Adv Respir Dis. déc 2019;13:1753466619831906.

51. Soria J-C, Ohe Y, Vansteenkiste J, Reungwetwattana T, Chewaskulyong B, Lee KH, et al. Osimertinib in Untreated EGFR -Mutated Advanced Non-Small-Cell Lung Cancer. N Engl J Med. 11 janv 2018;378(2):113-25.

52. Di Giacomo AM, Valente M, Cerase A, Lofiego MF, Piazzini F, Calabrò L, et al. Immunotherapy of brain metastases: breaking a « dogma ». J Exp Clin Cancer Res CR. 17 oct 2019;38(1):419.

\section{Annexes}




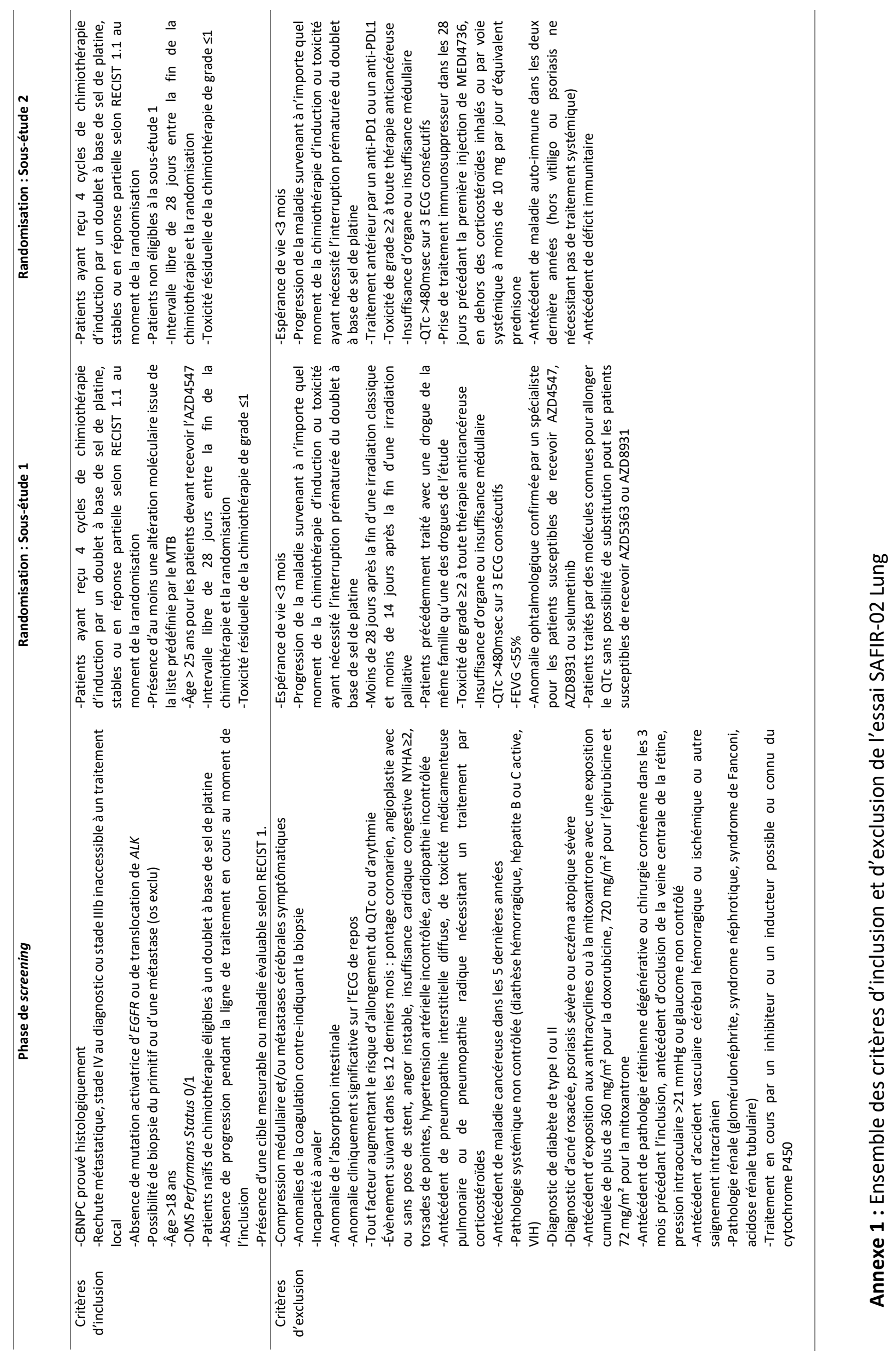




\begin{tabular}{|c|c|c|}
\hline Catégorie & Description & Thérapie ciblée \\
\hline \multirow{5}{*}{ A } & Altération de HER2 ou de RET ou & MET mut ou amp : Savolitinib \\
\hline & amplification FGFR1 ou mutation de & MAP $2 K 1 / 2$ : Vemurafenib + Cobimetinib \\
\hline & FGFR2 ou FGFR3 ou toute autre & Inactivation $B R C A 1 / 2$ ou $A T M$ : Olaparib \\
\hline & altération non mentionnée en $B, C$ & FGFR 1/2/3 : AZD4547 \\
\hline & et $D$ & Translocation de $R E T$ : Vandetanib \\
\hline \multirow{3}{*}{ B } & Absence d'altération $H E R 2, R E T$, & \\
\hline & FGFR1-2-3 ou $L K B 1$ mais mutation & Selumetinib \\
\hline & de KRAS ou BRAF & \\
\hline \multirow{5}{*}{ C } & Absence d'altération de $H E R 2, R E T$, & \\
\hline & FGFR1-2-3, LKB1, KRAS ou BRAF, & \\
\hline & mais mutation ou amplification de & AZD5363 \\
\hline & PIK3CA ou délétion ou mutation de & \\
\hline & PTEN ou mutation de $A K T 1$ & \\
\hline \multirow{3}{*}{ D } & Absence d'altération de $H E R 2, R E T$, & \\
\hline & FGFR1-2-3, KRAS, BRAF, PIK3CA, & AZD2014 \\
\hline & PTEN ou AKT1, mais mutation $L K B 1$ & \\
\hline
\end{tabular}

Annexe 2 : Classification des altérations moléculaires ciblables par le MTB 



\section{Serment d'Hippocrate}

Au moment d'être admise à exercer la médecine, je promets et je jure d'être fidèle aux lois de I'honneur et de la probité.

Mon premier souci sera de rétablir, de préserver ou de promouvoir la santé dans tous ses éléments, physiques et mentaux, individuels et sociaux.

Je respecterai toutes les personnes, leur autonomie et leur volonté, sans aucune discrimination selon leur état ou leurs convictions. J'interviendrai pour les protéger si elles sont affaiblies, vulnérables ou menacées dans leur intégrité ou leur dignité. Même sous la contrainte, je ne ferai pas usage de mes connaissances contre les lois de l'humanité.

J'informerai les patients des décisions envisagées, de leurs raisons et de leurs conséquences. Je ne tromperai jamais leur confiance et $n$ 'exploiterai pas le pouvoir hérité des circonstances pour forcer les consciences.

Je donnerai mes soins à l'indigent et à quiconque me les demandera. Je ne me laisserai pas influencer par la soif du gain ou la recherche de la gloire.

Admise dans l'intimité des personnes, je tairai les secrets qui me seront confiés. Reçue à l'intérieur des maisons, je respecterai les secrets des foyers et ma conduite ne servira pas à corrompre les mœurs.

Je ferai tout pour soulager les souffrances. Je ne prolongerai pas abusivement les agonies. Je ne provoquerai jamais la mort délibérément.

Je préserverai l'indépendance nécessaire à l'accomplissement de ma mission. Je n'entreprendrai rien qui dépasse mes compétences. Je les entretiendrai et les perfectionnerai pour assurer au mieux les services qui me seront demandés.

J'apporterai mon aide à mes confrères ainsi qu'à leurs familles dans l'adversité.

Que les hommes et mes confrères $\mathrm{m}^{\prime}$ accordent leur estime si je suis fidèle à mes promesses ; que je sois déshonorée et méprisée si j’y manque.

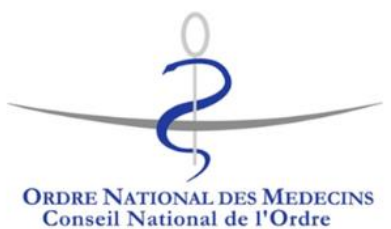



Introduction : Le cancer bronchique reste le premier pourvoyeur de métastases cérébrales $(\mathrm{MC})$, responsables d'une importante morbidité et mortalité. De plus, la réponse cérébrale aux traitements systémiques est inconstante et imprévisible du fait de plusieurs phénomènes. Tout d’abord, bien que les spécificités moléculaires et phylogéniques des métastases cérébrales soient toujours largement inconnues, on observe une hétérogénéité significative entre les métastases cérébrales et la tumeur primitive, suggérant l'existence d'un précurseur commun acquérant par la suite des altérations moléculaires. Les spécificités de la barrière hémato-encéphalique et les particularités du microenvironnement cérébral contribuent également au caractère inconstant de la réponse cérébrale. Nous avons mené une étude à partir des données de l'essai de phase II randomisé SAFIR-02 Lung. Notre objectif principal était de comparer les profils moléculaires des patients avec et sans MC. Notre objectif secondaire était d'évaluer la réponse intra-cérébrale en fonction du traitement de maintenance reçu, et du statut cérébral à l'inclusion.

Méthodes : Un total de 365 patients screenés dans l'essai SAFIR-02 Lung disposant de données moléculaires interprétables ont été inclus dans cette analyse. Les données cliniques et biologiques ont été recueillies. Les analyses génomiques reposaient sur la l'hybridation génomique comparative et le séquençage de nouvelle génération (NGS) suivant les recommandations du protocole.

Résultats : Les analyses génomiques initiales ont permis d'identifier une signature de 12 gènes (renforcée par 12 gènes adjacents), spécifique des cancers bronchiques avec MC. Tous les gènes identifiés avaient été précédemment décrits comme impliqués dans l'oncogenèse (TNS1, PAK2, COBL, CDK5, GLRX3, WNT5B, SETD1B, EGLN3, TOX3, RYR1, PVR et BCL2LL1). Les analyses en NGS ont retrouvé une proportion plus importante de mutations de KRAS dans le groupe porteur de métastases cérébrales (44,3\% versus 32,3\%), particulièrement de mutation G12C (63\% versus 47\%). De plus, l'analyse des interactions protéiques a mis en évidence plusieurs interactions centrées autour d'EGFR, apparaissant comme un driver de prolifération cérébrale malgré l'exclusion des mutations activatrices. Par ailleurs, le risque de progression cérébrale était réduit dans le bras traité par pemetrexed. Le taux le plus élevé de progression cérébrale était observé dans le bras traité par durvalumab.

Conclusion: Ce travail a identifié une signature de 24 gènes spécifique des cancers bronchiques avec MC. De futures études seront nécessaires pour préciser les implications fonctionnelles de ces gènes et mieux comprendre le processus métastatique cérébral dans l'objectif d'identifier, à partir de cette signature, de nouvelles cibles thérapeutiques pour la prise en charge des cancers bronchiques avec MC. 